\title{
Evidence for treatment of epidermal keratinocyte neoplasms
}

Citation for published version (APA):

Jansen, M. H. E. (2019). Evidence for treatment of epidermal keratinocyte neoplasms. [Doctoral Thesis, Maastricht University]. Ridderprint BV. https://doi.org/10.26481/dis.20190510mj

Document status and date:

Published: 01/01/2019

DOI:

10.26481/dis.20190510mj

Document Version:

Publisher's PDF, also known as Version of record

\section{Please check the document version of this publication:}

- A submitted manuscript is the version of the article upon submission and before peer-review. There can be important differences between the submitted version and the official published version of record.

People interested in the research are advised to contact the author for the final version of the publication, or visit the DOI to the publisher's website.

- The final author version and the galley proof are versions of the publication after peer review.

- The final published version features the final layout of the paper including the volume, issue and page numbers.

Link to publication

\footnotetext{
General rights rights.

- You may freely distribute the URL identifying the publication in the public portal. please follow below link for the End User Agreement:

www.umlib.nl/taverne-license

Take down policy

If you believe that this document breaches copyright please contact us at:

repository@maastrichtuniversity.nl

providing details and we will investigate your claim.
}

Copyright and moral rights for the publications made accessible in the public portal are retained by the authors and/or other copyright owners and it is a condition of accessing publications that users recognise and abide by the legal requirements associated with these

- Users may download and print one copy of any publication from the public portal for the purpose of private study or research.

- You may not further distribute the material or use it for any profit-making activity or commercial gain

If the publication is distributed under the terms of Article $25 \mathrm{fa}$ of the Dutch Copyright Act, indicated by the "Taverne" license above, 
EVIDENCE FOR TREATMENT OF EPIDERMAL KERATINOCYTE NEOPLASMS

Maud Jansen 
Printing of this thesis was financially supported by: Catharina Ziekenhuis Eindhoven, Galderma, La Roche-Posay, LEO Pharma, Louis Widmer, Merz BV, Pierre Fabre Mylan Healthcare B.V., Zuyderland Medisch Centrum

Cover design and layout: (c) evelienjagtman.com

Printing: $\quad$ Ridderprint, Ridderkerk, the Netherlands

ISBN:

$978-94-6375-327-2$

(C) copyright Maud Jansen, Maastricht 2019

All rights reserved. No part of this thesis may be reproduced or transmitted in any form or by any means without prior permission of the author, or when appropriate, of the publisher of the publications. 


\section{EVIDENCE FOR TREATMENT of EPIDERMAL \\ KERATINOCYTE NEOPLASMS}

PROEFSCHRIFT

ter verkrijgen van de graad van doctor aan de Universiteit van Maastricht, op gezag van de Rector Magnificus, Prof. Dr. Rianne M. Letschert,

volgens het besluit van het Collega van Decanen,

in het openbaar te verdedigen

op vrijdag 10 mei 2019, om 12.00 uur

door

Maud Henriëtte Elisabeth Jansen

geboren op 30 juni 1989 te 's-Hertogenbosch 


\section{Promotor}

Prof. dr. P.M. Steijlen

\section{Co-promotores}

Dr. K. Mosterd

Dr. N.W.J. Kelleners-Smeets

\section{Beoordelingscommisie}

Prof. dr. C. Dirksen (voorzitter)

Prof. dr. J. Cals

Prof. dr. T. Nijsten (Erasmus Medisch Centrum, Rotterdam)

Dr. R. Beljaards (Centrum Oosterwal, Sandstep Healthcare) 


\section{CONTENTS}

$\begin{array}{lll}\text { Chapter } 1 & \text { General introduction } & 7\end{array}$

$\begin{array}{lll}\text { Chapter } 2 & \text { Treatment of actinic keratosis } & 27\end{array}$

2.1 Randomized trial of four treatment approaches for actinic keratosis $\quad 29$

2.2 Cost-effectiveness of topical 5-fluorouracil versus imiquimod versus 53 ingenol mebutate versus photodynamic therapy in the treatment of actinic keratosis

\section{Chapter 3 Bowen's disease}

3.1 Trends in the incidence of Bowen's disease based on a single centre study in the Netherlands

3.2 Bowen's disease: long-term results of treatment with 5-fluorouracil cream, photodynamic therapy and surgical excision

Chapter 4 Long-term follow-up results in the treatment of superficial basal cell carcinoma

4.1 Five-year results of a randomized controlled trial comparing effectiveness of photodynamic therapy, topical imiquimod and 5-fluorouracil in patients with superficial basal cell carcinoma

4.2 Comparison of long-term cosmetic outcomes for different treatments of superficial basal cell carcinoma

Chapter 5 General discussion and valorization

Chapter 6 Summary

Samenvatting

Appendix Curriculum vitae 

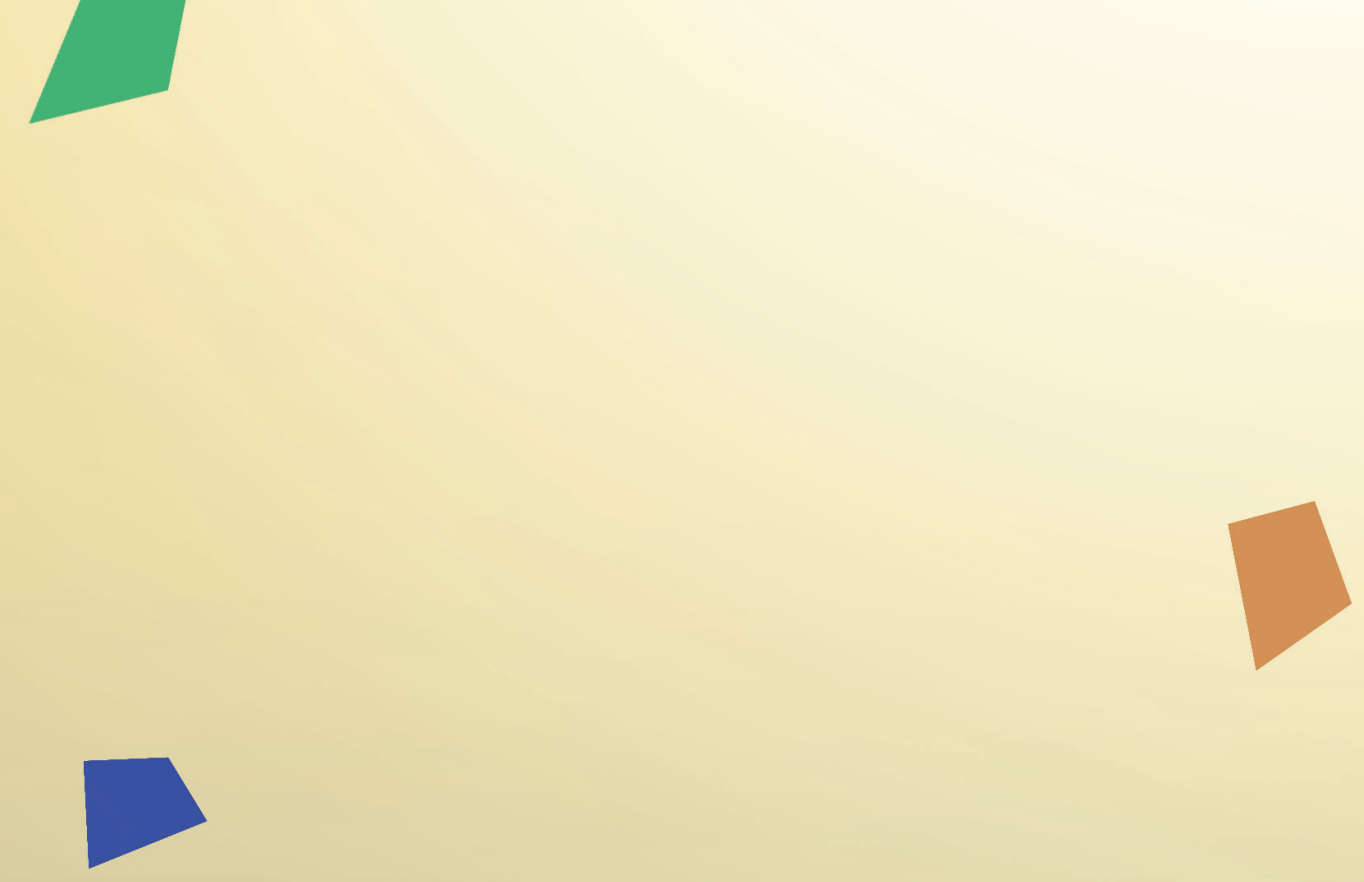

\section{CHAPTER 1}

General introduction

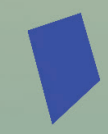





\section{SKIN CANCER}

Skin cancer is becoming a major health problem. ${ }^{1}$ Worldwide, it is the most common cancer in Caucasians. ${ }^{2}$ In the Dutch population, skin cancer is even the second most common cancer. ${ }^{3}$ The incidence of premalignant skin neoplasms is also increasing. In a cohort study performed in Rotterdam in persons aged 50 years or older, full skin examination revealed in $26.1 \%$ of the study population actinic keratosis (AK) and in 1 of 25 patients a cutaneous malignancy was found. ${ }^{4}$

Skin cancer can roughly be divided in melanoma and non-melanoma skin cancer. Malignant melanoma is the most aggressive form of skin cancer, but non-melanoma skin cancer (NMSC) is more prevalent. ${ }^{5,6}$ The most common forms of NMSC are basal cell carcinoma (BCC) and squamous cell carcinoma (SCC), also referred to as keratinocyte cancer.? Other types of NMSC compromise cutaneous lymphomas, Merkel cell carcinomas, adnexal tumours and other rare primary cutaneous carcinomas. ${ }^{2}$ Unlike BCC, SCC can arise from precursor lesions. These suspected precursors are AK and Bowen's disease.

The incidence of keratinocyte cancer and its precursors is still increasing. 2,8,9 These increasing incidences will cause a higher burden on the dermatologic practice and therefore evaluation of current diagnostic and treatment strategies is required. Nowadays, more and more treatment options are available for treatment of epidermal keratinocyte neoplasms but head-to-head comparison studies are sparse.

The studies in this thesis focus on comparison of different aspects of treatment modalities of three common epidermal keratinocyte neoplasms; AK, Bowen's disease and superficial BCC. These specific forms of epidermal keratinocyte neoplasms and the different treatment modalities are described in detail below.

\section{ACTINIC KERATOSIS}

Actinic keratosis (AK) is a common skin neoplasm that occurs mostly in elderly persons on sunexposed areas of the skin, such as the face, dorsal sides of the hands, upper trunk and the scalp in bald patients.

The prevalence of AK in the Netherlands is estimated on the basis of a large population-based cohort study performed in Rotterdam. ${ }^{10}$ In the population of 45 years and older, about half of the men and one third of the women had AK. ${ }^{10}$ 
AK is suggested to be a precancerous lesion and if left untreated it might develop into an invasive SCC..$^{11,12}$ Percentages of progression into a SCC range between $0.025 \%$ and $16 \%$ per AK lesion per year. ${ }^{13-15}$

There are several risk factors for the development of AK, such as male sex, an age of 70 years or older, skin wrinkles, the tendency to develop sunburn and light pigmentation (based on eye, hair, and skin colour). ${ }^{10}$ Organ transplantation, long-term use of immunosuppressive medication, exposure to skin carcinogens (e.g. arsenic) or sun, light skin phototype (Fitzpatrick I or II) and history of cutaneous SCC are predisposing medical conditions for AK. ${ }^{16}$

The clinical presentation of AK is a well-demarcated rough, erythematous papule or plaque with a white-yellowish scale (Figure 1). AK occurs especially in patients with a history of high sun exposure. The size can vary from a few millimetres to large coalesced plaques of a few centimetres. At first, there is only mild erythema with minimal keratosis, but later thick hyperkeratotic papules or plaques may develop. Lesions of AK can occur solitary; however, most patients suffer from many lesions in a large area, so-called field change or field cancerization. This field can consist of all grades of AK; both subclinical AK lesions and clinically obvious AK lesions. AK is usually asymptomatic, but patients may suffer from mild itching, sand paper-like texture or tenderness. ${ }^{17}$

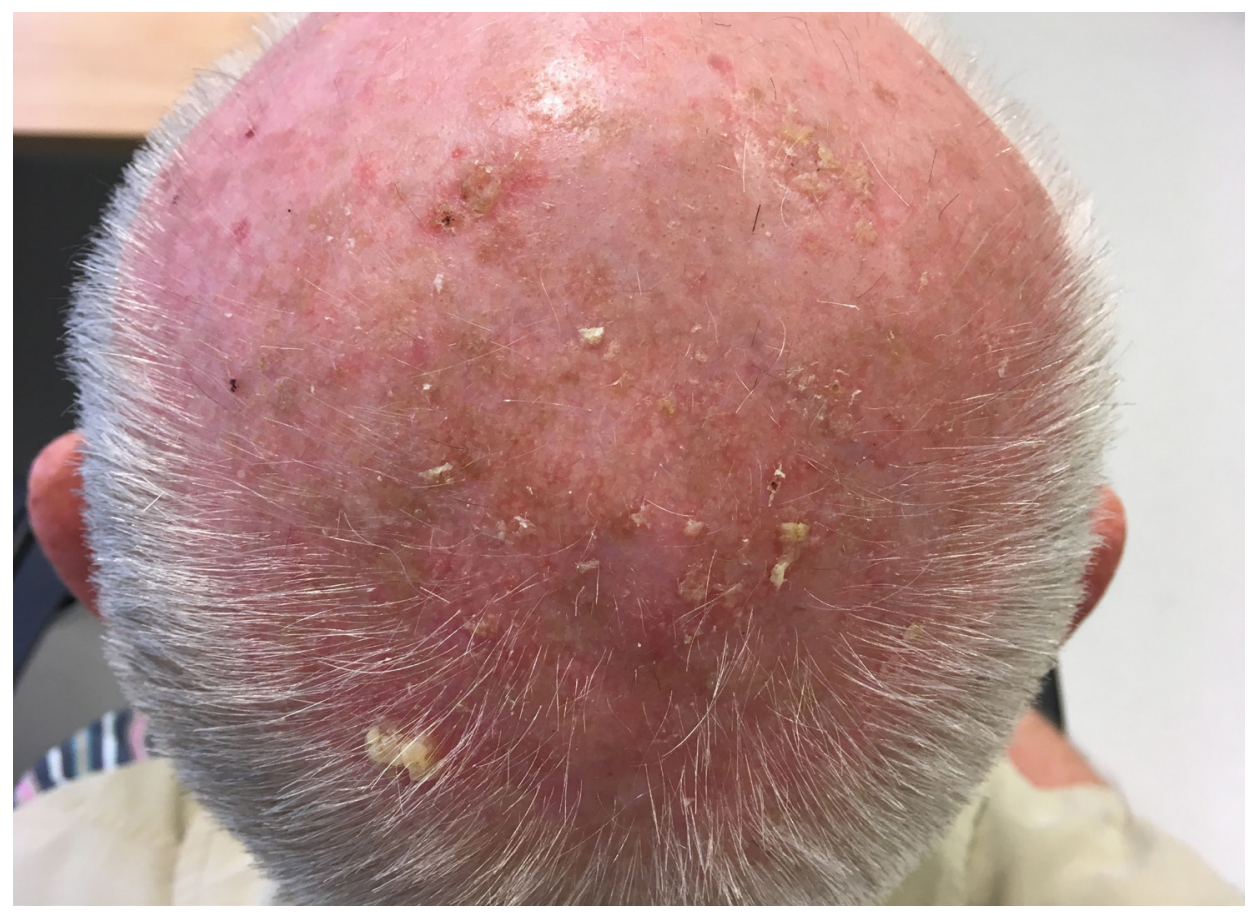

Figure 1. Clinical presentation of actinic keratosis. 
The severity of a single AK lesion can be assessed using the Olsen scale, which was proposed by Olsen et al. and is based on the overall thickness of AK. ${ }^{18}$ In this classification system, lesions are graded as Olsen Grade I when they are slightly palpable and more easily felt than seen; as Olsen Grade II when the lesions are moderately thick and easy to see and feel; and graded as Olsen Grade III when the lesions are very thick hyperkeratotic AK. This classification system is mainly used in clinical trials.

Generally, dermatologists can diagnose AK on the basis of the clinical features and therefore histological confirmation is not necessary. Sometimes, a biopsy is been performed, usually to exclude an invasive SCC. Clinical factors of AK that predict a higher risk of malignant transformation into an invasive SCC are described as the BEIRUD criteria: bleeding, erythema, induration/inflammation, rapid enlargement, ulceration and a diameter $>1 \mathrm{~cm} .{ }^{19}$ Pain of the lesion is also a reason to perform a biopsy. ${ }^{20}$

When a biopsy is performed, histopathologic features of AK are hyperkeratosis with intermittent large parakeratotic nuclei of the epidermis. Furthermore, there is loss of the granular layer of the epidermis and there is keratinocyte atypia of the basal layer. This basal layer is proliferative and can bud into the underlying dermis. In the dermis a superficial perivascular infiltrate can be present and solar elastosis is variably found. ${ }^{21}$

There are different reasons to treat AK. On the one hand AK is treated because it is thought to reduce the risk of skin cancer and the costs for subsequent treatment of a SCC.22,23 Besides this, relief of symptoms and improvement of the cosmetic appearance can also be reasons to treat AK. ${ }^{16,22}$ However, it should be kept in mind that treatment of AK may have significant side effects (such as redness and scaling) and that the risk of recurrence remains high.

For the treatment of AK different treatments are available. These different therapies are explained in more detail below. To date, there is no consensus on the most effective treatment for AK and current guidelines do not state clear recommendations on which treatment modality is preferred. ${ }^{24-27}$ Previous studies compared only a few therapies or compared a single treatment with placebo. Thus, there is need for a head-to-head trial of the most frequently used therapies for AK with long term results. 


\section{BOWEN'S DISEASE}

Bowen's disease is a cutaneous SCC in situ, which was first described in 1912 by JT Bowen. ${ }^{28}$ In literature, little is known about the incidence rate of Bowen's disease. The most recent publications reported an annual incidence rate of 22.4 per 100.000 women and 27.8 per 100.000 men in Canada and 142 per 100.000 persons in the Caucasian population of Hawaii. ${ }^{29,30}$ There is a small risk for progression of Bowen's disease into an invasive SCC.31,32

As with other types of epidermal keratinocyte neoplasms, exposure to UV light is one of the most important risk factors for Bowen's disease..$^{29}$ Other risk factors for the development of Bowen's disease include immunosuppression, human papillomavirus infection, and other agents such as arsenic and thermal injury. ${ }^{29}$

Typically, Bowen's disease presents as a slowly growing, erythematous, sharply demarcated, solitary, flat plaque with a crusted or scaling surface and an irregular border (Figure 2). ${ }^{29}$ Most lesions in Caucasian populations occur on sun-exposed areas, especially on head, neck and extremities. ${ }^{33-35}$

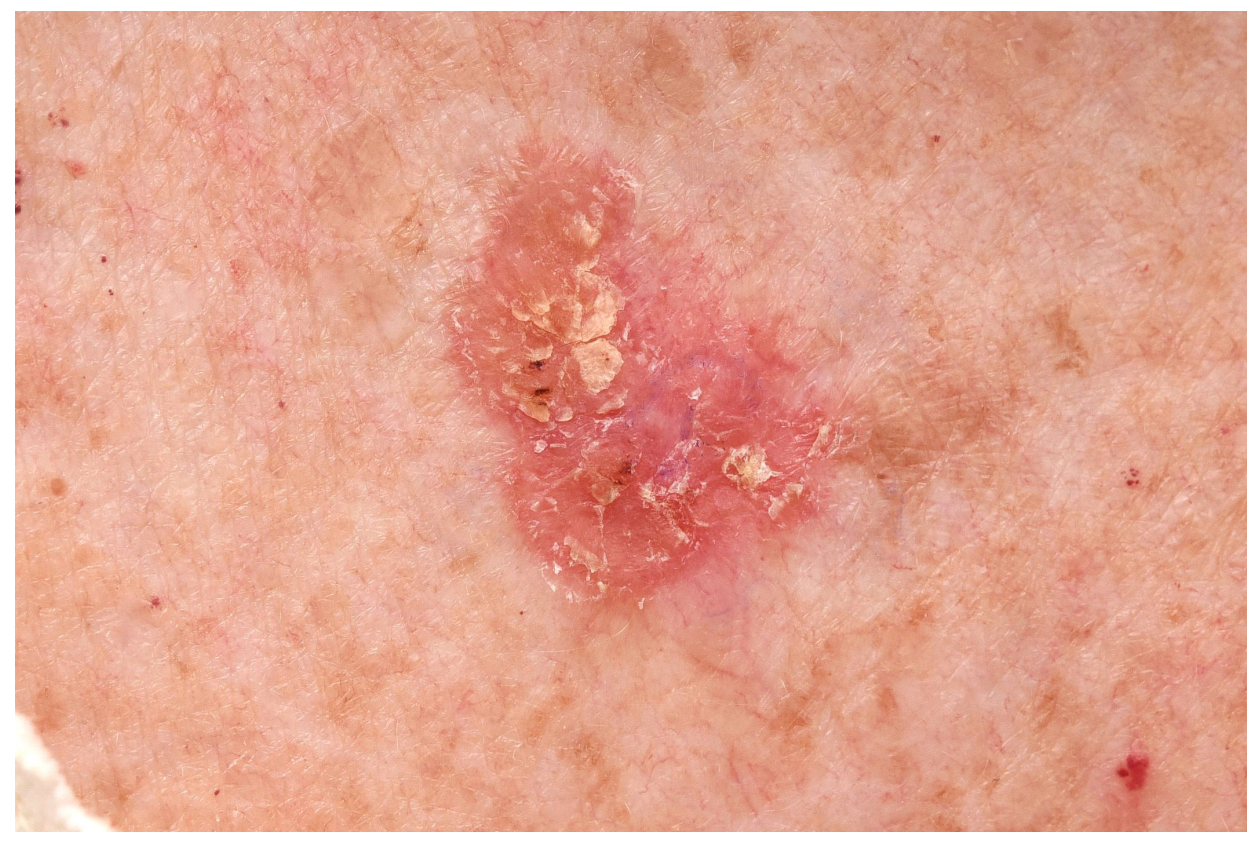

Figure 2. Clinical presentation of Bowen's disease. 
Histopathologically, the epidermis shows full-thickness atypia with dyskeratotic cells and some atypical mitoses. Furthermore, the epidermis is acanthotic and hyperkeratotic. Mild to moderate psoriatiform hyperplasia can be found and there is loss of epidermal polarity. ${ }^{21,29}$ No penetration of the disorganisation of the epidermal maturation is found in the dermis. ${ }^{29}$

For the treatment of Bowen's disease various invasive and non-invasive treatment modalities are described in the literature..$^{33,35-37}$ However, to date there is little consensus about the most effective treatment of Bowen's disease. The UK Guidelines give no firm advice about the most effective treatment and states that surgical excision is widely used, although the existing evidence is of lower quality than for photodynamic therapy (PDT) and 5-fluorouracil. ${ }^{33}$ PDT seems to be more effective than 5-fluorouracil. ${ }^{38-40}$ The French Guidelines recommend surgical excision for small, solitary tumours that are not on poor wound healing sites. ${ }^{37}$ Otherwise, non-invasive therapies such as PDT and 5-fluorouracil are advised. In the German Guidelines, the size and healing tendency are taken into account in choosing a therapy: cryotherapy or curettage followed by surgical excision or PDT is recommended in small, solitary tumours, PDT or 5-fluorouracil for large tumours and cryotherapy, PDT, curettage or 5-fluorouracil for multiple lesions. ${ }^{36}$ Currently, there are no Dutch guidelines for the treatment of Bowen's disease. However, the Dutch guidelines for the treatment of SCC harbour the (very limited) advise that Bowen's disease could be treated with surgical excision or PDT. ${ }^{41}$

\section{BASAL CELL CARCINOMA}

Basal cell carcinoma (BCC) is the most common cancer in humans. It is a slowly growing neoplasm deriving from the epidermis, in specific the basal layer and hair follicle epithelium. ${ }^{21}$ It is a locally aggressive tumour that rarely metastasizes and thus rarely causes death. However, if left untreated it can cause great morbidity due to destruction of adjacent tissues. BCC is usually located on sun-exposed areas of the skin.

In the Netherlands, one in five to six people will develop a BCC.,42 The incidence is still increasing, especially the incidence of superficial BCC and in younger people. ${ }^{9,43}$ BCCs are slightly more common in men than in women and most tumours occur in the head and neck region. ${ }^{42}$ Risk factors for the development of BCC are a complex of different subgroups, which can roughly be divided in environmental, phenotypic and genetic factors. The main environmental risk factor for BCC is ultraviolet (UV) radiation, which comprises intermittent UV exposure during holidays and outdoor activities as well as indoor tanning and UV-B and PUVA therapy. ${ }^{44}$ Ionizing radiation for other diseases in the past, exposure to the carcinogen arsenic and immunosuppressive drugs are

other environmental risk factors. Patients of older age, male sex, light hair, eye and skin colour, patients who got sunburned in childhood, with signs of actinic damage or a personal or family 
history of skin neoplasms have a higher risk of developing BCC because of their phenotype. ${ }^{44}$ Besides this, genetic factors play a role. In most BCC somatic mutations are found in tumour suppressor genes patched 1 (PTCH1), tumour protein 53 (TP53), and ACTRT1.44,45 There are also a few skin cancer syndromes including nevoid basal cell carcinoma syndrome and xeroderma pigmentosum (types A to G), Bazex-Dupre-Christol syndrome. All these factors mentioned above may interact and increase the risk of the development of a BCC. ${ }^{44}$

A BCC can be diagnosed based on its typical clinical appearance in most cases. Biopsy is performed to distinguish between different subtypes. BCCs can be divided in many different histological subtypes of which over 20 have been described. Although in literature different classifications are mentioned, these classifications lack uniformity of clear terminology and definition. ${ }^{46}$ A commonly used classification system divides BCCs in four different categories; nodular BCC (nBCC), infiltrative BCC, superficial BCC (sBCC) and mixed type BCC. ${ }^{46} \mathrm{nBCC}$ is the most frequent type of BCC, followed by the superficial and infiltrative subtypes. ${ }^{44}$ Depending on the subtype, a choice can be made about treatment options.

Because the focus of this thesis is on the treatment of the superficial subtype, only this type will be explained in more detail.

A sBCC presents itself as thin erythematous patches or plaques with mild to moderate scaling, superficial ulceration and well-defined borders (Figure 3). ${ }^{21}$ The diameter can vary and multiple lesions may be present. sBCC are mainly found on trunk and extremities. ${ }^{43,44}$

Clinically, sBCCs may be sometimes difficult to distinguish from AK, Bowen's disease or a benign inflammatory lesion and therefore, diagnosis is confirmed by histology.

Histopathologically, small nests of proliferating basal cells extending from the epidermis and outer root sheet of the hair follicle down to the superficial epidermis are found. These nests have a broad base of attachment to the epidermis. ${ }^{21,46}$ Palisading of the peripheral row of cells and retraction spaces from surrounding stroma is prominent and peritumoral mucin production can be seen. ${ }^{21}$

For the treatment of sBCC, surgical excision and various non-invasive therapies are well-known treatment modalities. To date, a lot of research on effectiveness, cosmetic results and patient preferences is performed regarding these different therapies. Whereas surgical excision remains superior to the other treatments in terms of effectiveness and is therefore considered first line treatment, topical therapies are well established for the treatment of sBCC. ${ }^{47,48}$ The different treatment modalities are more extensively described below. 


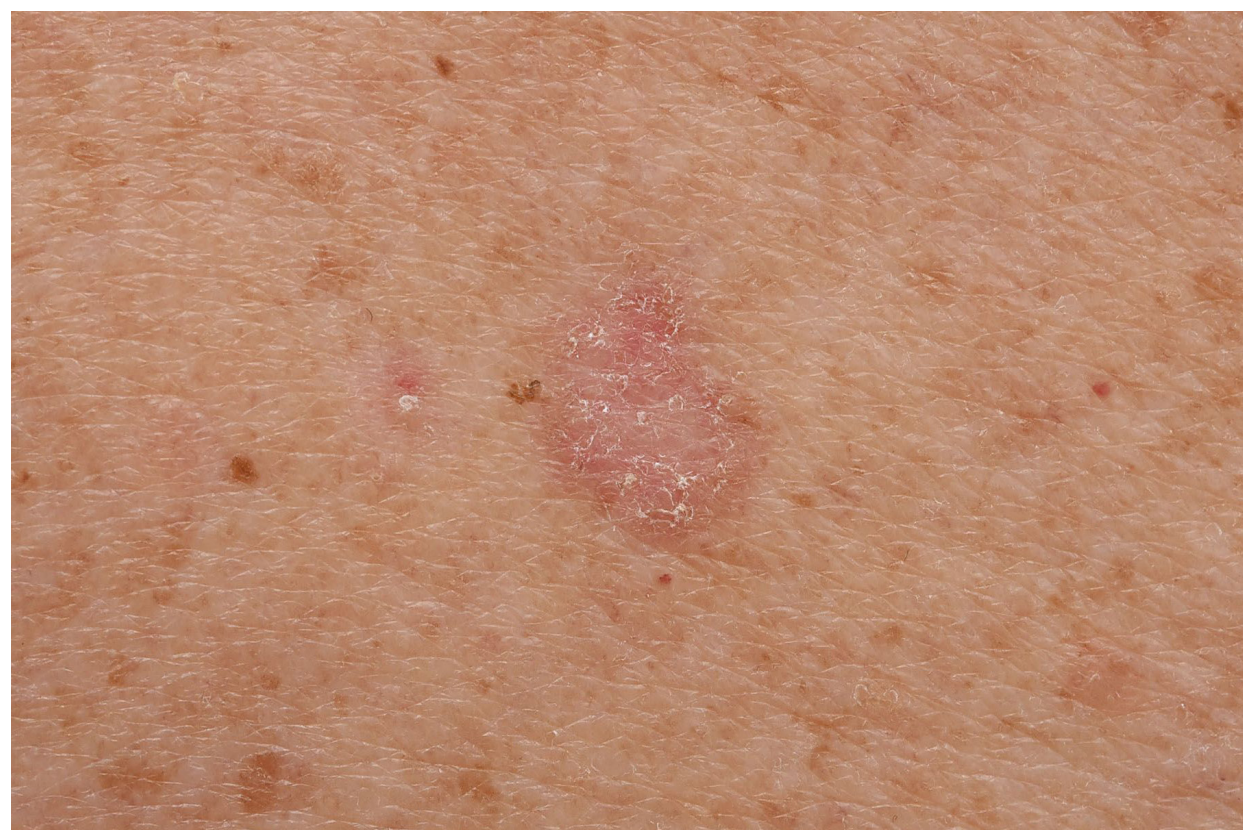

Figure 3. Clinical presentation of superficial basal cell carcinoma.

\section{TREATMENTS OF EPIDERMAL KERATINOCYTE NEOPLASMS}

There is a widespread variation in treatment modalities for epidermal keratinocyte neoplasms with differences in mode of action, mode of application, costs and cosmetic results.

For the treatment of AK, therapies can be divided into lesion-based or field-directed therapies. A lesion-based therapy is the treatment of an individual lesion, usually performed in small, single AKs. The most commonly used lesion-based treatment is cryotherapy, in which liquid nitrogen is used for freezing of the tumour. ${ }^{49}$ Freezing with consecutive thawing induces necrosis of the tissue. ${ }^{16}$ Treatment with cryotherapy is quick, easy and inexpensive. However, the effectiveness depends on the physician performing the therapy and there is a risk for hypoor hyperpigmentation after treatment. ${ }^{16}$ A different example of lesion directed therapies is curettage and electrocoagulation.

In field-directed therapies an area of sun-damaged skin, in which several clinical and subclinical AK lesions are present, is treated. Examples of field-directed therapies are topical 5-fluorouracil cream, imiquimod cream, PDT, ingenol mebutate gel, topical diclofenac in $2.5 \%$ hyaluronic acid gel and chemical peeling. ${ }^{22}$ 
Surgical excision is still the gold standard treatment for sBCC and Bowen's disease. However, the use of non-invasive therapies is well established for treatment of both tumours. Advantages of these non-invasive therapies are the often cosmetic superiority, the fact that treatment can be performed at home and that multiple tumours can be treated at once. Moreover, they might be preferred for tumours at locations where excision may be complicated by delayed wound healing, such as the lower legs.

Treatments that are investigated in this thesis will be further explained below.

\section{Surgical excision}

In surgical excision, the tumour is excised under local anaesthesia with a clinical safety margin. After excision, the specimen is examined by the pathologist to assess whether the tumour was excised completely.

An advantage of surgical excision is that histopathological evaluation following excision enables conf irmation of the diagnosis, gives information on the whole tumour and its characteristics and whether a tumour is eradicated completely. Recurrence rates 5 year after surgical excision range from 2 to $8 \%{ }^{48,50}$ However, surgical excision has several disadvantages, such as the possibility of a complication (bleeding, infection, pain) and the development of a scar. Moreover, surgical treatment often requires an extra visit to the hospital and the stress of a surgical procedure might influence the wellbeing of especially the elderly.

\section{Photodynamic therapy (PDT)}

The effect of photodynamic therapy is established by tissue destruction, caused by a combination of a photosensitizer, visible light and oxygen. For keratinocyte neoplasms 5-aminolaevulinic acid (5-ALA) and methylaminolevulinate (MAL) are commonly used photosensitizers. After application of 5-ALA or MAL-cream to the affected skin, these photosensitizers are converted within the cells into the photosensitizer protoporphyrin IX (PpIX). The intracellular porphyrins convert oxygen into a range of reactive oxygen species (ROS). The produced ROS cause direct destruction of the tumour by necrosis and/or apoptosis. Furthermore, the ROS production also causes destruction of the tumour vessels and produces an inflammatory response, which attracts leukocytes to the treated tumour. ${ }^{51}$

MAL-cream (Metvix ${ }^{\circledR}$, Galderma) is registered for the treatment of AK, sBCC and Bowen's disease. ${ }^{52}$ The 5-ALA cream (Ameluz ${ }^{\circledR}$, Biofrontera Bioscience $\mathrm{GmbH}$ ) is registered for sBCC and $A K{ }^{53}$ In the Netherlands, MAL-cream is most commonly used. 
For treatment with conventional PDT, MAL- or 5-ALA-cream is applied to the treatment area and covered by an occlusive dressing, in order to prevent contact with (UV) light. After 3 hours incubation time the area is illuminated with a light emitting diode (LED). For the treatment of AK, only one illumination is used. For treatment of Bowen's disease and SBCC, a second illumination is performed after a one-week interval. After the treatment the illuminated area is covered again with an occlusive dressing, to prevent exposure to daylight during 48 hours. ${ }^{52.53}$

This treatment is an in-hospital therapy and is performed by authorized nurses. Two days after the treatment patients should prevent sun exposure. The local skin reactions, which can appear after treatment, such as erythema, crusts and a burning sensation usually, disappear within one to two weeks.

Pain is a common complaint during conventional PDT treatment. Recently, daylight-PDT (d-PDT) is available for treatment of AK. ${ }^{54}$ For d-PDT, UV daylight is used instead of red light. After application of MAL-cream and an incubation time of maximum 30 minutes, patients should stay outdoors for 2 hours in full daylight. Following the 2 hour exposure period, the cream should be washed off. ${ }^{52}$ The main advantage of $\mathrm{d}$-PDT is that it is less painful. ${ }^{54,55} \mathrm{~A}$ limitation of this treatment is the weather condition, as this therapy is only suitable when the temperature conditions are suitable to stay outdoors and on non-rainy days.

\section{Imiquimod cream}

Imiquimod is a topical immune response modifier that works via the acquired and innate immune system. Its mechanism of action is mainly via Toll-like receptors 7 and 8 , located on antigen-presenting cells. Binding of imiquimod to these receptors causes stimulation of the pathway, inducing the activation of the central transcription factor, nuclear factor-kappa $B$ $(\mathrm{NF}-\mathrm{kB})$. This activation leads to production and release of several cytokines and chemokines (e.g. tumour necrosis factor-alpha (TNF- $a$ ), interferon gamma (IFN- $\gamma$ ), interferon alpha (IFN- $a$ ) and interleukins). These cytokines and chemokines stimulate the innate and acquired immune system, resulting in antitumor activity. ${ }^{56}$ Besides its action via the immune system, imiquimod also binds to the Fas receptor. By binding to a Fas receptor ligand, a cascade of events is stimulated including activation of caspase, and leading to cellular death of the tumour cells. ${ }^{56}$

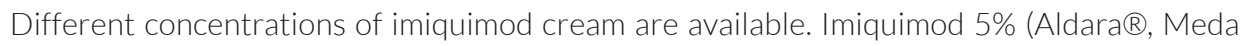
Pharmaceuticals) cream is used three days per week (Monday, Wednesday, Friday) during four consecutive weeks for treatment of AK. After a 4-week treatment-free period, a physician should assess clearance of AKs. For the treatment of sBCC, the cream is applied once daily, five consecutive days a week for six weeks. 
Since August 2012 imiquimod 3.75\% cream (Zyclara ${ }^{\circledR}$, Meda Pharmaceuticals) is available. Advantages of imiquimod 3.75\% might be fewer side effects and the less complicated treatment schedule of two cycles of two consecutive weeks, with a two-week interval, which is thought to lead to more compliance. ${ }^{22}$

Most side effects from treatment with imiquimod are local skin reactions: erythema, itching, burning, irritation, erosions and ulceration..$^{57}$ In some cases patients can experience flu-like symptoms, as fever, nausea and fatigue. These side effects usually do not require treatment and resolve when application of imiquimod is stopped.

\section{5\% 5-fluorouracil cream}

5-fluorouracil (Efudix $®$, Meda Pharmaceuticals) cream is a topically applied chemotherapeutic which interferes with DNA synthesis. It was the first topical therapy approved by the FDA for the treatment of sBCC. Binding of 5-fluorouracil to cofactor 5,10-methylene tetrahydrofolate, which causes binding to thymidylate synthase, inhibits thymidylate synthase. As a result, conversion of deoxyuridine to thymidine nucleotides fails. This failure leads to inhibition of DNA synthesis, prevents cell proliferation, and causes tumour necrosis. ${ }^{56}$

For the treatment of sBCC, AK and Bowen's disease 5-fluorouracil cream is applied twice daily during four weeks. Almost similar side effects as mentioned with imiquimod occur during treatment with 5-fluorouracil, with the exception of the flu-like symptoms. During treatment local skin reactions, such as erythema and crusts, will appear in most patients. After the treatment erythema, crusts and tenderness will persist for approximately one to two weeks.

\section{Ingenol mebutate gel}

Ingenol mebutate gel (Picato $\AA$, LEO Pharma A/S) is one of the newest therapies for the treatment of AK and is reimbursed by the Dutch healthcare insurances since October 2013.

Ingenol mebutate is derived from a milkweed named Euphorbia peplus. ${ }^{58}$ It has a dual action mode; rapid lesion necrosis and specific activation of the immune system. ${ }^{58,59}$ The acute effects rely on the induction of lesion necrosis. Application of ingenol mebutate results in swelling of the mitochondria, disruption of the cytoplasmic organelles and membrane disruption/ depolarization. ${ }^{58}$ After this induced necrosis, due to the release pro-inflammatory cytokines by the cells undergoing necrosis, an inflammatory response of mainly neutrophils occurs. B cells produce antibodies, which bind to antigens on dysplastic epidermal cells and bind to receptors on neutrophils. By binding on the receptors of the neutrophils, the killing mechanisms of the neutrophils are activated, which causes release of cytotoxic agents (e.g. reactive oxygen species (ROS)). This destructs the dysplastic epidermal cells. ${ }^{58}$ 
Two concentrations of ingenol mebutate gel are available. For treatment of AK on the face and scalp, the $0.015 \%$ gel has to be applied by the patient at home once daily for three consecutive days on a continuous area of $25 \mathrm{~cm}^{2}$. Application of the $0.05 \%$ gel for two consecutive days is used for treatment of AK located on the trunk or extremities.

The main advantage of treatment with ingenol mebutate is a shorter duration of treatment and consequently a shorter downtime, compared to imiquimod and 5-fluorouracil.

Side effects reported are almost equivalent to the use of imiquimod or 5-fluorouracil cream and will disappear within approximately 2 weeks after application. However, the rate of eyelid oedema after treatment with ingenol mebutate gel is higher compared with 5-fluorouracil cream. ${ }^{60}$

\section{AIMS OF THIS THESIS}

The aim of this thesis was to evaluate existing treatments to contribute to improve treatment strategies for patients with epidermal neoplasms. The following questions will be answered:

\section{Actinic keratosis}

What is the most (cost) effective treatment when comparing topical treatment with 5\% 5-fluorouracil cream, 5\% imiquimod cream, methylaminolevulinate photodynamic therapy (MAL-PDT), and 0.015\% ingenol mebutate gel in treatment of AK? (Chapter 2)

In literature several treatment modalities are described. However, there is no consensus on the most (cost) effective treatment option for AK. In the existing guidelines for AK there are no clear recommendations for treatment modality. ${ }^{24,27,61}$ Therefore, currently the treatment choice mainly relies on physician's and patient's preferences.

A systematic review performed by Gupta et al. in 2012, concluded that trials with direct comparisons are necessary. ${ }^{11}$ Furthermore, the follow-up period of most trials is short. As AK is a common skin condition with a high recurrence rate following treatment, it is of great importance to gain more knowledge about the (cost) effectiveness of the field-directed therapies.

The aim of chapter $\mathbf{2}$ is to find out which of the four frequently prescribed field-directed treatments for AK is the most (cost) effective. A large prospective randomised controlled multicentre trial with 12 months of follow-up has been performed. 


\section{Bowen's Disease}

Is there a trend in the incidence of Bowen's disease? (Chapter 3.1)

In the last decades the incidence of BCC and SCC is increasing. In contrast with these two forms of keratinocyte cancer, there is little information about the incidence of Bowen's disease. To date, estimates of the incidence rates largely derive from studies in the United States and Canada and show large variation with 10-fould differences in incidence rates. ${ }^{29,62,63}$ To the best of our knowledge, there are no studies that estimate the incidence or incidence trends of Bowen's disease in the Caucasian population living in Europe. Information about incidence trends can help to predict the effects on the health care system and thereby influence the choice of treatment. An increase can induce a shift towards more frequent use of non-invasive therapies for the treatment of Bowen's disease to reduce the burden on healthcare budgets.

Chapter 3.1 is devoted to explore whether the incidence of Bowen's disease is increasing in our region.

Is the effectiveness of treatment with 5-fluorouracil and PDT comparable to surgical excision in the treatment of primary Bowen's disease? (Chapter 3.2)

Compared to the increasing evidence that non-invasive treatment modalities are effective for treatment of BCC and SCC, there is little evidence and uniformity in the treatment of Bowen's disease. ${ }^{33,35,37}$ Consideration of patient and tumour characteristics, patient preferences and costs are advised when choosing therapy. ${ }^{33,35,37}$ Invasive treatment with surgical excision and non-invasive treatment with PDT are both mentioned as first choice in various guidelines. ${ }^{33,37}$ Studies comparing different treatments are essential in the process of shared decision-making.

The aim of chapter 3.2 is to evaluate the effectiveness of three commonly used therapies for the treatment of Bowen's disease in our hospital.

\section{Superficial basal cell carcinoma}

What is the effectiveness of treatment with imiquimod 5\% cream and 5-fluorouracil compared to MAL-PDT, 5 years after the treatment of primary SBCC? (Chapter 4.1)

Surgical excision is the first line treatment for BCC. Different studies suggest that topical therapies can be a useful clinical alternative to surgical excision in treatment of sBCC.48,50,64 We previously showed that the effectiveness of imiquimod is superior and 5-fluorouracil is not inferior compared with MAL-PDT after one and three year of follow-up. ${ }^{65,66}$ Both topical treatments were more cost-effective than treatment with MAL-PDT. ${ }^{67}$ No significant difference in effectiveness between imiquimod and 5-fluorouracil was found. To date, there are only a 
few studies published that report data on long-term follow-up effectiveness of sBCC. ${ }^{50,68}$ Such studies are necessary to compare effectiveness of different non-invasive treatments..$^{50,68}$

The aim of chapter 4.1 is to compare the effectiveness results 5 years post-treatment of three non-invasive treatment modalities for sBCC. A prospective non-inferiority randomised controlled multi-centre trial was performed.

Which treatment has the best cosmetic outcome after treatment of sBCC with PDT, imiquimod or 5-fluorouracil, five years post-treatment? (Chapter 4.2)

Because of the increasing incidence of BCC at a younger age, cosmetic outcome after treatment is becoming a more important aspect. 1,9,42,43 Previous studies showed better cosmetic results after treatment with PDT compared to surgical excision for treatment of superficial and nodular BCC. $64,69,70$ Furthermore, a significant difference in cosmetic outcome, in favour of imiquimod, was found in a study that compared surgical excision and imiquimod for nodular and superficial BCC six months and three years after treatment. ${ }^{71}$ The one year follow-up results of our own study showed slightly better cosmetic results after treatment with MAL-PDT compared with imiquimod and 5-fluorouracil. ${ }^{66}$

In chapter 4.2 the cosmetic outcome of different treatment modalities for sBCC is evaluated after five years of follow-up.

In chapter 5 the results are discussed and includes a valorisation paragraph. 


\section{REFERENCES}

1. Lomas A, Leonardi-Bee J, Bath-Hextall F. A systematic review of worldwide incidence of nonmelanoma skin cancer. The British journal of dermatology. 2012;166(5):1069-1080.

2 Madan V, Lear JT, Szeimies RM. Non-melanoma skin cancer. Lancet. 2010;375(9715):673-685.

3. IKNL. www.cijfersoverkanker.nl. 2017; www.cijfersoverkanker.nl.

4. Sanders MG, Pardo LM, Verkouteren JA, Hamann SA, Hamer MA, Nijsten T. Dermatological screening of a middle-aged and elderly population: the Rotterdam Study. The British journal of dermatology. 2017; 177(4):e98-e100.

5. Forsea AM, Del Marmol V, de Vries E, Bailey EE, Geller AC. Melanoma incidence and mortality in Europe: new estimates, persistent disparities. The British journal of dermatology. 2012;167(5):11241130.

6. Augustin J, Kis A, Sorbe C, Schafer I, Augustin M. Epidemiology of Skin Cancer in the German Population: Impact of Socioeconomic and Geographic Factors. Journal of the European Academy of Dermatology and Venereology: JEADV. 2018;32(11):1906-1913.

7. Karimkhani C, Boyers LN, Dellavalle RP, Weinstock MA. It's time for "keratinocyte carcinoma" to replace the term "nonmelanoma skin cancer". Journal of the American Academy of Dermatology. 2015;72(1):186187.

8. Hollestein LM, de Vries E, Nijsten T. Trends of cutaneous squamous cell carcinoma in the Netherlands: increased incidence rates, but stable relative survival and mortality 1989-2008. European journal of cancer (Oxford, England: 1990). 2012;48(13):2046-2053.

9. Flohil SC, de Vries E, Neumann HA, Coebergh JW, Nijsten T. Incidence, prevalence and future trends of primary basal cell carcinoma in the Netherlands. Acta dermato-venereologica. 2011;91(1):24-30.

10. Flohil SC, van der Leest RJ, Dowlatshahi EA, Hofman A, de Vries E, Nijsten T. Prevalence of actinic keratosis and its risk factors in the general population: the Rotterdam Study. The Journal of investigative dermatology. 2013;133(8):1971-1978.

11. Dinehart SM, Nelson-Adesokan P, Cockerell C, Russell S, Brown R. Metastatic cutaneous squamous cell carcinoma derived from actinic keratosis. Cancer. 1997;79(5):920-923.

12. Ackerman AB, Mones JM. Solar (actinic) keratosis is squamous cell carcinoma. Br J Dermatol. 2006;155(1):9-22.

13. Marks R, Rennie G, Selwood TS. Malignant transformation of solar keratoses to squamous cell carcinoma. Lancet. 1988;1(8589):795-797.

14. Salasche SJ. Epidemiology of actinic keratoses and squamous cell carcinoma. Journal of the American Academy of Dermatology. 2000;42(1 Pt 2):4-7.

15. Gloster HM, Jr., Brodland DG. The epidemiology of skin cancer. Dermatologic surgery: official publication for American Society for Dermatologic Surgery [et al]. 1996;22(3):217-226.

16. Dreno B, Amici JM, Basset-Seguin N, Cribier B, Claudel JP, Richard MA. Management of actinic keratosis: a practical report and treatment algorithm from AKTeam expert clinicians. Journal of the European Academy of Dermatology and Venereology : JEADV. 2014;28(9):1141-1149.

17. Siegel JA, Korgavkar K, Weinstock MA. Current perspective on actinic keratosis: a review. The British journal of dermatology. 2017;177(2):350-358.

18. Olsen EA, Abernethy ML, Kulp-Shorten C, et al. A double-blind, vehicle-controlled study evaluating masoprocol cream in the treatment of actinic keratoses on the head and neck. Journal of the American Academy of Dermatology. 1991;24(5 Pt 1):738-743.

19. Quaedvlieg PJ, Tirsi E, Thissen MR, Krekels GA. Actinic keratosis: how to differentiate the good from the bad ones? European journal of dermatology: EJD. 2006;16(4):335-339. 
20. Calzavara-Pinton P, Haedersdal M, Barber K, et al. Structured Expert Consensus on Actinic Keratosis: Treatment Algorithm Focusing on Daylight PDT. Journal of cutaneous medicine and surgery. 2017:1203475417702994.

21. Raymond L. Barnhill ANC, Cynthia M. Magro, Michael W. Piepkorn. Dermatopathology. 3th ed2010.

22. Gupta AK, Paquet M, Villanueva E, Brintnell W. Interventions for actinic keratoses. The Cochrane database of systematic reviews. 2012;12:Cd004415.

23. Yoon J, Phibbs CS, Chow A, Weinstock MA. Impact of Topical Fluorouracil Cream on Costs of Treating Keratinocyte Carcinoma (Nonmelanoma Skin Cancer) and Actinic Keratosis. Journal of the American Academy of Dermatology. 2018;79(3):501-507 e502.

24. de Berker D, McGregor JM, Mohd Mustapa MF, Exton LS, Hughes BR. British Association of Dermatologists' guidelines for the care of patients with actinic keratosis 2017. The British journal of dermatology. 2017;176(1):20-43.

25. NVDV. Richtlijn actinische keratose. 2012.

26. Werner RN, Stockfleth E, Connolly SM, et al. Evidence- and consensus-based (S3) Guidelines for the Treatment of Actinic Keratosis - International League of Dermatological Societies in cooperation with the European Dermatology Forum - Short version. Journal of the European Academy of Dermatology and Venereology: JEADV. 2015.

27. Beljaards RC, van der Sande A. Update richtlijn actinische keratosen 2017. Nederlands Tijdschrift voor Dermatologie en Venereologie. 2017;27(04):190-192.

28. Bowen JT. Centennial paper. May 1912 (J Cutan Dis Syph 1912;30:241-255). Precancerous dermatoses: a study of two cases of chronic atypical epithelial proliferation. By John T. Bowen, M.D., Boston. Arch Dermatol. 1983;119(3):243-260.

29. Arlette JP, Trotter MJ. Squamous cell carcinoma in situ of the skin: history, presentation, biology and treatment. Australas J Dermatol. 2004;45(1):1-9; quiz 10.

30. Reizner GT, Chuang TY, Elpern DJ, Stone JL, Farmer ER. Bowen's disease (squamous cell carcinoma in situ) in Kauai, Hawaii. A population-based incidence report. Journal of the American Academy of Dermatology. 1994;31(4):596-600.

31. Peterka ES, Lynch FW, Goltz RW. An association between Bowen's disease and internal cancer. Arch Dermatol. 1961;84:623-629.

32. Kao GF. Carcinoma arising in Bowen's disease. Arch Dermatol. 1986;122(10):1124-1126.

33. Morton CA, Birnie AJ, Eedy DJ. British Association of Dermatologists' guidelines for the management of squamous cell carcinoma in situ (Bowen's disease) 2014. The British journal of dermatology. 2014;170(2):245-260.

34. Hansen JP, Drake AL, Walling HW. Bowen's Disease: a four-year retrospective review of epidemiology and treatment at a university center. Dermatologic surgery: official publication for American Society for Dermatologic Surgery [et al]. 2008;34(7):878-883.

35. Bath-Hextall FJ, Matin RN, Wilkinson D, Leonardi-Bee J. Interventions for cutaneous Bowen's disease. The Cochrane database of systematic reviews. 2013;6:Cd007281.

36. Szeimies RM, Karrer S, Backer H. [Therapeutic options for epithelial skin tumors. Actinic keratoses, Bowen disease, squamous cell carcinoma, and basal cell carcinoma]. Der Hautarzt; Zeitschrift fur Dermatologie, Venerologie, und verwandte Gebiete. 2005;56(5):430-440.

37. Bonerandi JJ, Beauvillain C, Caquant L, et al. Guidelines for the diagnosis and treatment of cutaneous squamous cell carcinoma and precursor lesions. Journal of the European Academy of Dermatology and Venereology: JEADV. 2011;25 Suppl 5:1-51. 
38. Morton C, Horn M, Leman J, et al. Comparison of topical methyl aminolevulinate photodynamic therapy with cryotherapy or Fluorouracil for treatment of squamous cell carcinoma in situ: Results of a multicenter randomized trial. Arch Dermatol. 2006;142(6):729-735.

39. Salim A, Leman JA, McColl JH, Chapman R, Morton CA. Randomized comparison of photodynamic therapy with topical 5-fluorouracil in Bowen's disease. The British journal of dermatology. 2003;148(3):539-543.

40. Perrett CM, McGregor JM, Warwick J, et al. Treatment of post-transplant premalignant skin disease: a randomized intrapatient comparative study of 5-fluorouracil cream and topical photodynamic therapy. The British journal of dermatology. 2007;156(2):320-328.

41. Venereologie NVvDe. Guideline squamous cell carcinoma of the skin. 2010; https://www.huidarts.info.

42. Flohil SC, Seubring I, van Rossum MM, Coebergh JW, de Vries E, Nijsten T. Trends in Basal cell carcinoma incidence rates: a 37-year Dutch observational study. The Journal of investigative dermatology. 2013;133(4):913-918.

43. Arits AH, Schlangen MH, Nelemans PJ, Kelleners-Smeets NW. Trends in the incidence of basal cell carcinoma by histopathological subtype. Journal of the European Academy of Dermatology and Venereology : JEADV. 2011;25(5):565-569.

44. Verkouteren JA, Ramdas KH, Wakkee M, Nijsten T. Epidemiology of basal cell carcinoma: scholarly review. The British journal of dermatology. 2017;177(2):359-372.

45. Bal E, Park HS, Belaid-Choucair Z, et al. Mutations in ACTRT1 and its enhancer RNA elements lead to aberrant activation of Hedgehog signaling in inherited and sporadic basal cell carcinomas. Nature medicine. 2017;23(10):1226-1233.

46. Rippey JJ. Why classify basal cell carcinomas? Histopathology. 1998;32(5):393-398.

47. Bichakjian CK, Olencki T, Aasi SZ, et al. Basal Cell Skin Cancer, Version 1.2016, NCCN Clinical Practice Guidelines in Oncology. Journal of the National Comprehensive Cancer Network: JNCCN. 2016;14(5):574597.

48. Trakatelli M, Morton C, Nagore E, et al. Update of the European guidelines for basal cell carcinoma management. European journal of dermatology: EJD. 2014;24(3):312-329.

49. Goldberg LH, Kaplan B, Vergilis-Kalner I, Landau J. Liquid nitrogen: temperature control in the treatment of actinic keratosis. Dermatologic surgery : official publication for American Society for Dermatologic Surgery [et al]. 2010;36(12):1956-1961.

50. Williams HC, Bath-Hextall F, Ozolins M, et al. Surgery Versus $5 \%$ Imiquimod for Nodular and Superficial Basal Cell Carcinoma: 5-Year Results of the SINS Randomized Controlled Trial. The Journal of investigative dermatology. 2017;137(3):614-619.

51. Castano AP, Mroz P, Hamblin MR. Photodynamic therapy and anti-tumour immunity. Nature reviews Cancer. 2006;6(7):535-545.

52. Ltd GU.SmPC Metvix cream. https://www.medicines.org.uk/emc/product/6777/smpc. Accessed 201805-02,

53. GmbH BB. SmPC Ameluz cream. https://www.medicines.org.uk/emc/product/3158/smpc. Accessed 2018-05-02.

54. Philipp-DormstonWG, Sanclemente G, Torezan L, et al. Daylight photodynamic therapy with MAL cream for large-scale photodamaged skin based on the concept of 'actinic field damage': recommendations of an international expert group. Journal of the European Academy of Dermatology and Venereology: JEADV. 2016;30(1):8-15.

55. Lacour JP, Ulrich C, Gilaberte Y, et al. Daylight photodynamic therapy with methyl aminolevulinate cream is effective and nearly painless in treating actinic keratoses: a randomised, investigator-blinded, controlled, phase III study throughout Europe. Journal of the European Academy of Dermatology and Venereology: JEADV. 2015;29(12):2342-2348. 
56. Micali G, Lacarrubba F, Nasca MR, Schwartz RA. Topical pharmacotherapy for skin cancer: part I. Pharmacology. Journal of the American Academy of Dermatology. 2014;70(6):965.e961-912; quiz 977968.

57. Hanna E,Abadi R, Abbas O. Imiquimod in dermatology: an overview. International journal of dermatology. 2016;55(8):831-844.

58. Rosen RH, GuptaAK, Tyring SK. Dual mechanism of action of ingenol mebutate gel for topical treatment of actinic keratoses: rapid lesion necrosis followed by lesion-specific immune response. Journal of the American Academy of Dermatology. 2012;66(3):486-493.

59. Emmert S, Haenssle HA, Zibert JR, et al. Tumor-Preferential Induction of Immune Responses and Epidermal Cell Death in Actinic Keratoses by Ingenol Mebutate. PloS one. 2016;11(9):e0160096.

60. Samorano LP, Torezan LA, Sanches JA. Evaluation of the tolerability and safety of a $0.015 \%$ ingenol mebutate gel compared to 5\% 5-fluorouracil cream for the treatment of facial actinic keratosis: a prospective randomized trial. Journal of the European Academy of Dermatology and Venereology: JEADV. 2015;29(9):1822-1827.

61. Venereologie NVvDe. Guideline Actinic Keratosis. 2017; https://www.huidarts.info.

62. Chute CG, Chuang TY, Bergstralh EJ, Su WP. The subsequent risk of internal cancer with Bowen's disease. A population-based study. Jama. 1991;266(6):816-819.

63. Reizner GT, Chuang T-Y, Elpern DJ, Stone JL, Farmer ER. Bowen's disease (squamous cell carcinoma in situ) in Kauai, Hawaii. Journal of the American Academy of Dermatology. 1994;31(4):596-600.

64. Szeimies RM, Ibbotson S, Murrell DF, et al. A clinical study comparing methyl aminolevulinate photodynamic therapy and surgery in small superficial basal cell carcinoma (8-20 mm), with a 12-month follow-up. Journal of the European Academy of Dermatology and Venereology: JEADV. 2008;22(11):1302-1311.

65. Roozeboom MH, Arits AH, Mosterd K, et al. Three-Year Follow-Up Results of Photodynamic Therapy vs. Imiquimod vs. Fluorouracil for Treatment of Superficial Basal Cell Carcinoma: A Single-Blind, Noninferiority, Randomized Controlled Trial. The Journal of investigative dermatology. 2016;136(8):1568-1574.

66. Arits AH, Mosterd K, Essers BA, et al. Photodynamic therapy versus topical imiquimod versus topical fluorouracil for treatment of superficial basal-cell carcinoma: a single blind, non-inferiority, randomised controlled trial. Lancet Oncol. 2013;14(7):647-654.

67. Arits AH, Spoorenberg E, Mosterd K, Nelemans P, Kelleners-Smeets NW, Essers BA. Cost-effectiveness of topical imiquimod and fluorouracil vs. photodynamic therapy for treatment of superficial basal-cell carcinoma. The British journal of dermatology. 2014;171(6):1501-1507.

68. Roozeboom MH, Arits AH, Nelemans PJ, Kelleners-Smeets NW. Overall treatment success after treatment of primary superficial basal cell carcinoma: a systematic review and meta-analysis of randomized and nonrandomized trials. The British journal of dermatology. 2012;167(4):733-756.

69. Cosgarea R, Susan M, Crisan M, Senila S. Photodynamic therapy using topical 5-aminolaevulinic acid vs. surgery for basal cell carcinoma. Journal of the European Academy of Dermatology and Venereology: JEADV. 2013;27(8):980-984.

70. Rhodes LE, de Rie MA, Leifsdottir R, et al. Five-year follow-up of a randomized, prospective trial of topical methyl aminolevulinate photodynamic therapy vs surgery for nodular basal cell carcinoma. Arch Dermatol. 2007;143(9):1131-1136.

71. Bath-Hextall F, Ozolins M, Armstrong SJ, et al. Surgical excision versus imiquimod $5 \%$ cream for nodular and superficial basal-cell carcinoma (SINS): a multicentre, non-inferiority, randomised controlled trial. The Lancet Oncology. 2014;15(1):96-105. 

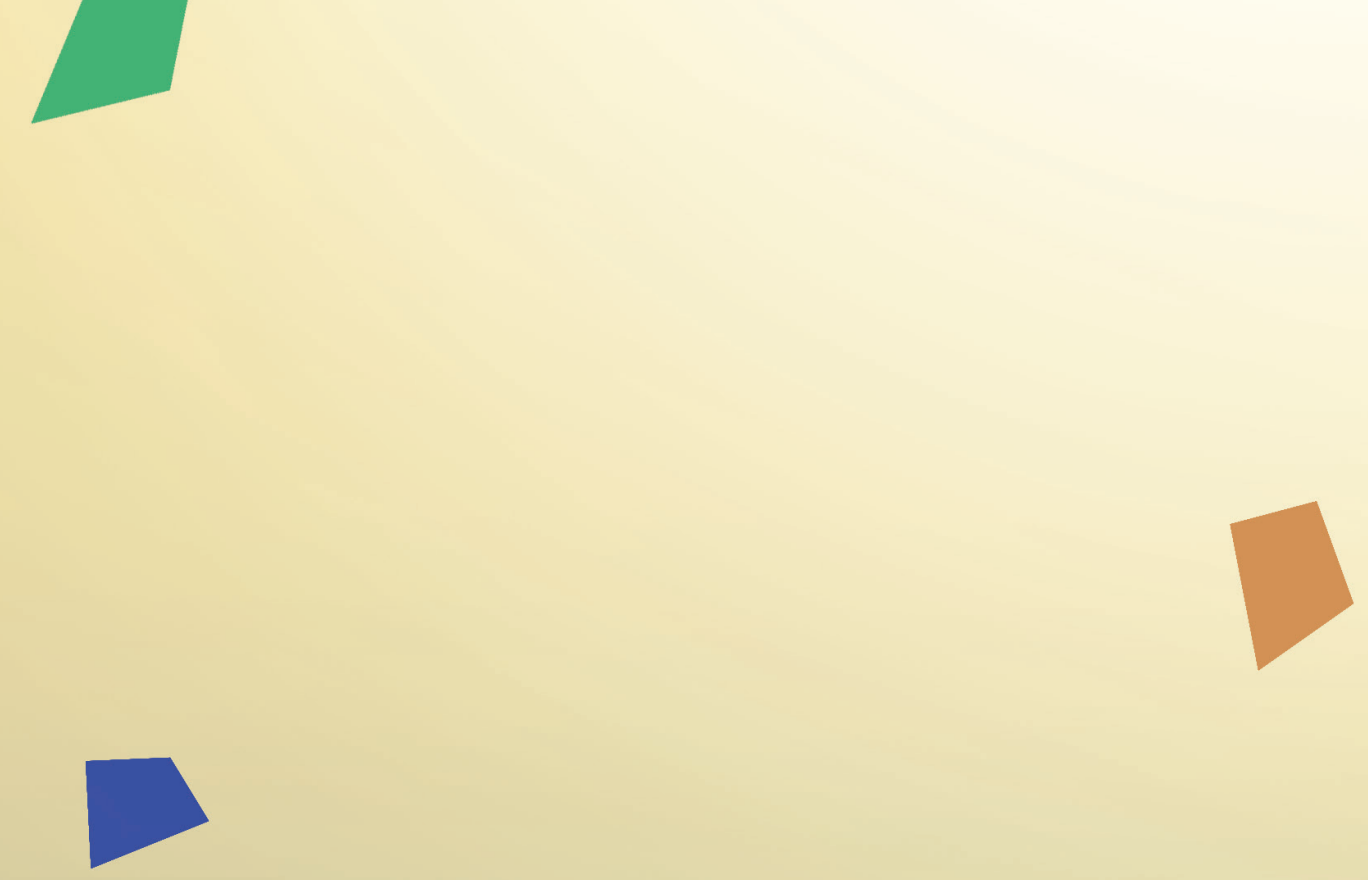

\section{CHAPTER 2}

Treatment of actinic keratosis 



\section{ABSTRACT}

\section{Background}

Actinic keratosis is the most frequent premalignant skin disease in the Caucasian population. In current guidelines, no clear recommendations are made about which treatment is preferred. We aimed to investigate the effectiveness of four frequently used field-directed treatments.

\section{Methods}

Patients with a clinical diagnosis of $\geq 5$ actinic keratosis lesions in the head and neck area, involving one continuous area of $25-100 \mathrm{~cm}^{2}$, were enrolled in four Dutch hospitals. Patients were randomly assigned to treatment with 5\% 5-fluorouracil cream, 5\% imiquimod cream, methylaminolevulinate photodynamic therapy (MAL-)PDT, or 0.015\% ingenol mebutate gel. The primary outcome was the proportion of patients with $\geq 75 \%$ reduction in the number of baseline actinic keratosis lesions at 12-months post-treatment. Both a modified intention-totreat and a per-protocol analysis were performed.

\section{$\underline{\text { Results }}$}

A total of 624 patients were included from November 2014 through March 2017. At 12 months after the end of treatment, the cumulative probability of remaining free from treatment failure was significantly higher among patients who received 5-fluorouracil (74.7\%; 95\% confidence interval (Cl) 66.8-81.0), than among patients who received imiquimod (53.9\%; 95\% Cl 45.461.6), MAL-PDT (37.7\%; $95 \%$ Cl 30.0-45.3), or ingenol mebutate (28.9\%; 95\% Cl 21.8-36.3). As compared with 5-fluorouracil, the hazard ratio for treatment failure was $2.03(95 \% \mathrm{Cl} 1.36$ $3.04 p=0.001$ ), 2.73 (95\% Cl 1.87-3.99 $p<0.001$ ), and 3.33 (95\% Cl 2.29-4.85 $p<0.001$ ) for imiquimod, MAL-PDT, and ingenol mebutate, respectively.

\section{Conclusions}

Twelve months after treatment of patients with multiple grade I-III actinic keratosis in the head and neck area, 5\% 5-fluorouracil cream was the most effective field-directed treatment. (ClinicalTrials.gov, number NCT02281682) 


\section{INTRODUCTION}

Actinic keratosis is the most frequent premalignant skin disease in the Caucasian population and is caused by ultraviolet radiation. With a prevalence of 37.5\% among Caucasians aged 50 years or older, it is one of the most frequent reasons for patients to visit a dermatologist. ${ }^{1-3}$ If left untreated, actinic keratosis might develop into squamous cell carcinoma. ${ }^{4,5}$ However, no definable clinical characteristics distinguish which actinic keratosis lesion pose a risk and what proportion of actinic keratosis will progress into a carcinoma. Percentages that have been reported in studies range between $0.025 \%$ and $16 \%$ per actinic keratosis lesion per year..$^{6-9}$

The recurrence rate after treatment is high, often leading to repetitive treatments, although a research suggests that the effect of 5 -fluorouracil on actinic keratosis reduction can last for years. ${ }^{10,11}$ Solitary lesions can be treated with cryotherapy. However, patients with actinic keratosis often present with multiple lesions in one continuous area (so-called field change). Generally, field-directed therapies are preferred, because they not only are therapeutically effective for present actinic keratosis but also may have a prophylactic effect on the development of new lesions; in addition, they may prevent the development of squamous cell carcinoma. ${ }^{11-13}$

Current guidelines provide no clear recommendations about which treatment approach is preferred. ${ }^{14-16}$ Frequently prescribed and studied field-directed treatment modalities are 5-fluorouracil cream, imiquimod cream, photodynamic therapy (PDT), and ingenol mebutate gel.

Currently, choice of treatment often depends on the preferences of patients and their treating physicians. Evidence from randomized trials with direct comparison between treatments and with long-term follow-up is scarce. ${ }^{11}$ The aim of this randomized, controlled trial was to directly compare treatment success at 12 months of 5-fluorouracil, imiquimod, MAL-PDT, and ingenol mebutate in patients with actinic keratosis lesions of any grade.

\section{METHODS}

\section{Trial design and population}

This multicentre single-blind, randomized trial was conducted at dermatology departments of four hospitals in the Netherlands. The study was performed according to the declaration of Helsinki, and the protocol (available with the full text of this article at NEJM.org) was approved by the local medical ethics committee. No commercial support was provided for the trial. The trial drugs were purchased as a part of routine care of the patients. No company had any role in the design, the collection or analysis of the data, or writing of the manuscript. The authors vouch for the completeness and accuracy of the data and analyses and for the fidelity of the trial to the protocol. 
Patients $\geq 18$ years with a clinical diagnosis of $\geq 5$ actinic keratosis lesions in one continuous area of skin of $25-100 \mathrm{~cm}^{2}$ in the head and neck area were eligible for participation. Clinical diagnosis of actinic keratosis was made by the patient's own physician and verified by one of two investigators who assessed the endpoints without knowing the treatment assignment. In case of a larger affected area, the investigator selected the area with the most pronounced lesions. All grades of actinic keratosis (Olsen grades I-III, a three-point grading system based on thickness of hyperkeratosis, with higher grades indicating more severe lesions) were included. (For details on the Olsen scale, see the Supplementary Appendix). Patients were not eligible to participate if they had received any treatment for actinic keratosis (including cryotherapy) in the target area or had used systemic retinoids or systemic immunosuppressant drugs within 3 months before inclusion. Other reasons for exclusion were suspicion of cancer in the target area, porphyria, allergy to study drugs, pregnancy or breast-feeding or a personal history of a genetic skin cancer disorder. All patients provided written informed consent before randomization.

\section{Randomization, treatment and assessments}

Patients were randomly assigned to one of four investigated treatments in a 1:1:1:1 ratio. Randomization lists that were based on minimization were computer generated with ALEA software. ${ }^{18}$ Stratifying factors were treatment centre and severity of actinic keratosis. One of two investigators who was aware of the treatment assignments (JK) performed the randomization procedure. JK was also responsible for the distribution of study information and medication and managed and recorded the adverse events as well as compliance. The other investigator (MJ) who was blinded to treatment allocation evaluated all trial endpoints, with the exception of adverse events and compliance during the baseline and follow-up visits.

MJ determined the number and extent of actinic keratosis lesions at the baseline visit and at 3 and 12 months after the end of treatment. All lesions were drawn with their exact location on a transparent sheet using physical reference points as landmarks. The severity of each lesion was graded with the Olsen scale. ${ }^{19}$ Owing to the nature of study medication, patients could not be blinded for treatment allocation.

Details about the treatment protocols of 5-fluorouracil, imiquimod, ingenol mebutate, and MALPDT are provided in the Supplementary Appendix. In all patients, superficial curettage of all actinic keratosis lesions was performed manually before every (re)treatment and patients did not receive anesthesia.

The treatment strategy entailed a first treatment and allowed for a retreatment in case of insufficient treatment response, defined as $<75 \%$ lesion response at the first follow-up visit (Figure 1). For patients assigned to 5-fluorouracil, ingenol mebutate or MAL-PDT, initial treatment response was evaluated 3 months after the first treatment. For patients assigned to imiquimod, 
initial response was evaluated 1 month after the last treatment day, in accordance with the summary of product characteristics guideline for imiquimod. All patients could receive a maximum of two courses of the allocated treatment. In case of $<75 \%$ clearance of actinic keratosis 3 months after the final treatment, those patients were assessed as treatment failures for the final analysis.

\section{Outcomes}

The primary outcome of this trial was the proportion of patients who remained free from treatment failure during 12 months follow-up after the last treatment. Treatment failure was defined as $<75 \%$ reduction in the number of actinic keratosis lesions counted at baseline and could occur at 3 months after the last treatment (initial failure) or at 12 months after initial successful treatment. Secondary outcomes were initial treatment success at 3 months after the last treatment (defined as $\geq 75 \%$ reduction of the number of actinic keratosis) compared to baseline, adverse events, compliance, patient satisfaction, health related quality of life (HRQoL), and cosmetic results. Details are provided in the Supplementary Appendix.

\section{Statistical analyses}

The sample size of this study was based on the primary endpoint, $\geq 75 \%$ lesion reduction at 12 months post-treatment. On the basis of previous studies, we estimated that $65 \%$ of patients would have $\geq 75 \%$ lesion reduction at 12 months after the end of treatment. ${ }^{21}$ To enable detection of a $15 \%$ difference between treatment groups with a power of $80 \%$ and alpha level of 5\%, a total of 140 patients were required per treatment group. To account for a potential loss to follow-up of $10 \%$, a total of $624(4 \times 156)$ patients needed to be included.

The cumulative probability of remaining free from treatment failure at 12 months after the end of treatment was calculated with the use of Kaplan-Meier survival analysis of the observed outcome data at 3 and 12 months. Survival analysis was used to account for patients who were lost to followup and were censored at the date of last follow-up visit.

Cox regression analysis was used to calculate hazard ratios for treatment failure with 95\% confidence intervals $(95 \% \mathrm{Cl})$ and $p$-values using the treatment with highest treatment success as reference group. Variables with dichotomous outcomes were compared between the treatment groups using the Chi-square test or Fisher's exact test for proportions. For continuous variables, between-group differences were compared using analysis of variance (if normally distributed) or a non-parametric test for independent samples (if not-normally distributed).

A Bonferroni adjustment was made for multiple comparisons with the use of $0.008(0.05 / 6)$ as the alpha value, because there are six possible pairwise comparisons between treatment groups. Analyses were performed using SPSS version 23.0 (IBM Corp., Armonk, NY, USA) and STATA version 14.0 (STATA Corp, College Station, TX, U.S.A.). 


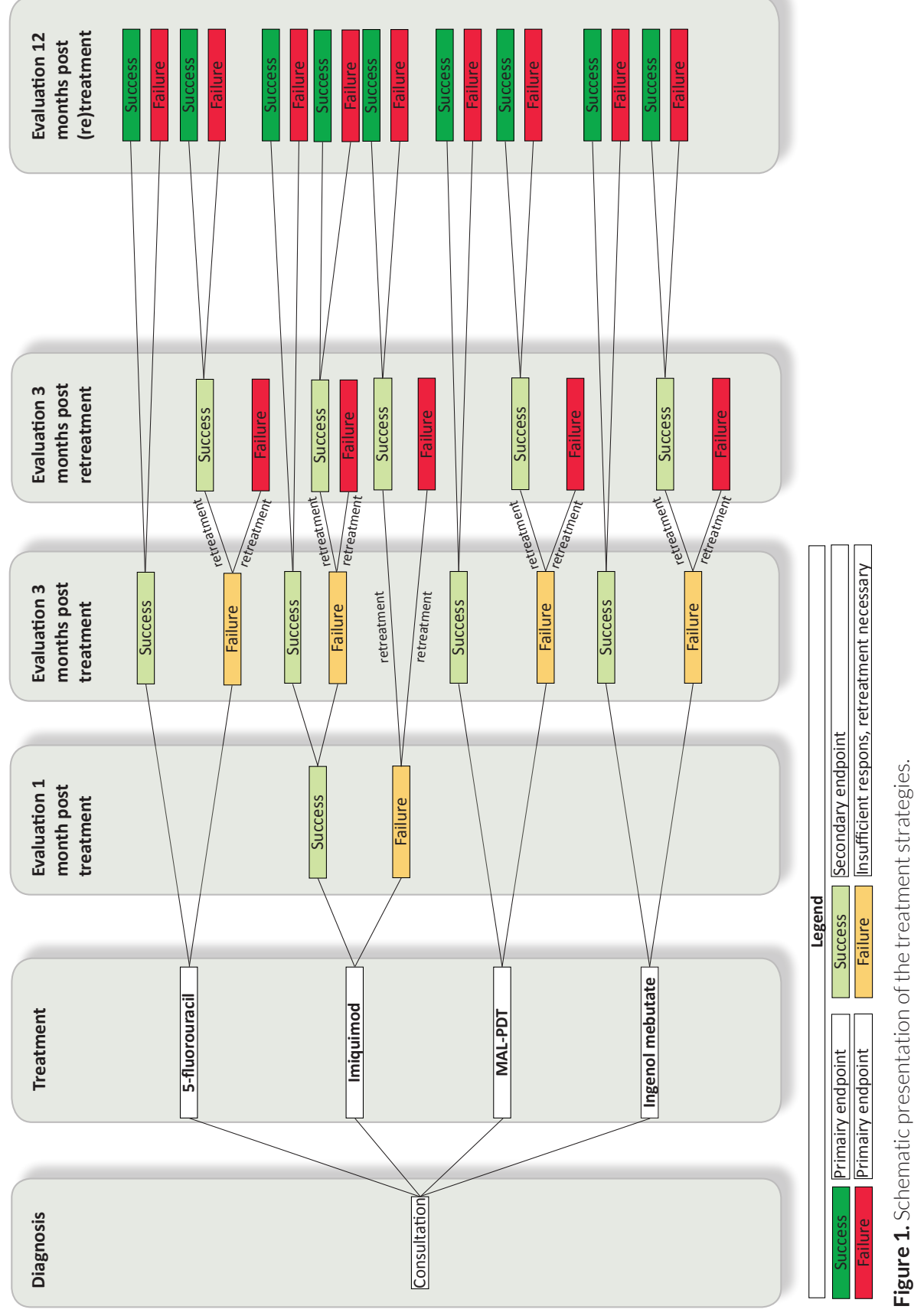




\section{RESULTS}

\section{Trial population}

Between November 2014 and March 2017, a total of 1174 patients were assessed for eligibility (Figure 2). Of those, 550 patients declined to participate for the following reasons: preference or disfavor regarding one or more of the studied treatments ( $n=197)$, old age or coexisting conditions ( $n=113$ ), disapproval to receive a treatment by randomization $(n=88)$, decision of the patient not to have actinic keratosis treated $(n=53)$, logistic reasons $(n=24)$, concern about possible side effects ( $n=24)$, treatment costs $(n=9)$, and preference for treatment in a different hospital $(n=3)$. One patient died before informed consent could be obtained, and 38 patients did not give a reason for declining to participate.

A total of 624 patients underwent randomization in four hospitals: Maastricht University Medical Centre (247 patients), Catharina Hospital Eindhoven (176 patients), VieCuri Medical Centre (108 patients), and Zuyderland Medical Centre (93 patients). A total of 155 patients were randomized to 5-fluorouracil, 156 to imiquimod, 156 to MAL-PDT, and 157 to ingenol mebutate. A total of 14 patients did not start treatment, and 8 patients were treated but did not attend the 3-month follow-up visit. Between 3 and 12 months, 14 patients were lost to follow-up (Figure 2). Eight cross-overs occurred before the assigned treatment was started, all because patients preferred a different therapy: one patient assigned to 5-fluorouracil received MAL-PDT; two patients (one assigned to imiquimod and one to ingenol mebutate) received 5-fluorouracil; of 5 patients allocated to PDT, 3 received 5-fluorouracil, and 2 ingenol mebutate. No substantial imbalances in baseline characteristics were observed between treatment groups (Table 1).

\section{Effectiveness}

A modified intention to treat ( $\mathrm{mITT}$ ) analysis was based on 602 randomized patients who started treatment and for whom the primary outcome was available. A total of 14 patients who declined treatment after randomization and 8 patients with early loss to follow-up were excluded (Table S1). In the mITT analysis, data were analyzed according to the treatment to which the patient was assigned by randomization.

The cumulative probability of treatment success for 5-fluorouracil was $74.7 \%$ (95\% Cl 66.881.0). For imiquimod, MAL-PDT, and ingenol mebutate, these percentages were $53.9 \%(95 \% \mathrm{Cl}$ 45.4-61.6), 37.7\% (95\% Cl 30.0-45.3), and 28.9\% (95\% Cl 21.8-36.3), respectively, according to the mITT-analysis (Table 2). A Bonferroni adjustment was made for multiple comparisons using an alpha of $0.008(0.05 / 6)$, and the differences between 5-fluorouracil cream and imiquimod, $\mathrm{PDT}$, and ingenol mebutate were statistically significant. 
Table 1. Baseline characteristics of the modified intention-to-treat population*

\begin{tabular}{|c|c|c|c|c|c|}
\hline Characteristic & $\begin{array}{l}\text { Total } \\
(n=624)\end{array}$ & $\begin{array}{l}5-\mathrm{FU} \\
(\mathrm{n}=155)\end{array}$ & $\begin{array}{l}\text { Imiquimod } \\
(n=156)\end{array}$ & $\begin{array}{l}\text { MAL-PDT } \\
(n=156)\end{array}$ & $\begin{array}{l}\mathrm{IM} \\
(\mathrm{n}=157)\end{array}$ \\
\hline \multicolumn{6}{|l|}{ Sex } \\
\hline Male & $558(89.4 \%)$ & $136(87.7 \%)$ & 143 (91.7\%) & $140(89.7 \%)$ & $139(88.5 \%)$ \\
\hline Female & $66(10.6 \%)$ & $19(12.3 \%)$ & 13 (8.3\%) & $16(10.3 \%)$ & $18(11.5 \%)$ \\
\hline $\begin{array}{l}\text { Age in years } \\
\text { median (range) }\end{array}$ & 73 [48-94] & $74[48-90]$ & 73 [59-89] & $73[55-90]$ & 72 [51-94] \\
\hline \multicolumn{6}{|l|}{ Skin type } \\
\hline I & 245 (39.3\%) & $63(40.6 \%)$ & 67 (42.9\%) & $54(34.6 \%)$ & $61(38.9 \%)$ \\
\hline ॥ & $333(53.4 \%)$ & 81 (52.3\%) & $79(50.6 \%)$ & 92 (59.0\%) & 81 (51.6\%) \\
\hline III & $46(7.4 \%)$ & $11(7.1 \%)$ & $10(6.4 \%)$ & $10(6.4 \%)$ & $15(9.6 \%)$ \\
\hline \multicolumn{6}{|l|}{ History of AK } \\
\hline Yes & 487 (78\%) & 121 (78.1\%) & $129(82.7 \%)$ & 115 (73.7\%) & $122(77.7 \%)$ \\
\hline No & $137(22 \%)$ & $34(21.9 \%)$ & $27(17.3 \%)$ & 41 (26.3\%) & 35 (22.3\%) \\
\hline \multicolumn{6}{|l|}{$\begin{array}{l}\text { History of } \\
(\mathrm{N}) \mathrm{MSC}^{* *}\end{array}$} \\
\hline Yes & $353(56.6 \%)$ & 90 (58.1\%) & $82(52.6 \%)$ & 86 (55.1\%) & $95(60.5 \%)$ \\
\hline No & $271(43.4 \%)$ & 65 (41.9\%) & $74(47.4 \%)$ & 70 (44.9\%) & $62(39.5 \%)$ \\
\hline \multicolumn{6}{|l|}{ Sun exposure } \\
\hline Mild & 19 (3.0\%) & $6(3.9 \%)$ & $5(3.2 \%)$ & $5(3.2 \%)$ & $3(1.9 \%)$ \\
\hline Moderate & $283(45.4 \%)$ & $69(44.5 \%)$ & $73(46.8 \%)$ & 72 (46.2\%) & $69(43.9 \%)$ \\
\hline Severe & $322(51.6 \%)$ & $80(51.6 \%)$ & $78(50.0 \%)$ & $79(50.6 \%)$ & 85 (54.1\%) \\
\hline \multicolumn{6}{|l|}{$\begin{array}{l}\text { History of immu- } \\
\text { nosuppressive } \\
\text { drugs***** }\end{array}$} \\
\hline Yes & 84 (13.5\%) & $18(11.6 \%)$ & 25 (16.0\%) & $19(12.2 \%)$ & 22 (14.0\%) \\
\hline No & 540 (86.5\%) & $137(88.4 \%)$ & 131 (84.0\%) & $137(87.8 \%)$ & 135 (86.0\%) \\
\hline $\begin{array}{l}\text { Treated area } \\
\text { in } \mathrm{cm}^{2} \text { median } \\
\text { (range) }\end{array}$ & 81 [25-100] & 80 [27-100] & 86.5 [25-100] & 81 [25-100] & 78 [25-100] \\
\hline $\begin{array}{l}\text { \# AK lesions } \\
\text { median (range) }\end{array}$ & $16[5-48]$ & $16[5-48]$ & $16.5[5-37]$ & $16[5-38]$ & 15 [5-40] \\
\hline \multicolumn{6}{|l|}{ Severity of AK } \\
\hline $\begin{array}{l}\text { Olsen grade I } \\
\text { and II }\end{array}$ & 575 (92.1\%) & $144(92.9 \%)$ & $143(91.7 \%)$ & $144(92.3 \%)$ & 144 (91.7\%) \\
\hline $\begin{array}{l}\geq 1 \text { lesion Ol- } \\
\text { sen grade III }\end{array}$ & 49 (7.9\%) & 11 (7.1\%) & $13(8.3 \%)$ & 12 (7.7\%) & 13 (8.3\%) \\
\hline
\end{tabular}


Table 1. Continued.

\begin{tabular}{|c|c|c|c|c|c|}
\hline Characteristic & $\begin{array}{l}\text { Total } \\
(n=624)\end{array}$ & $\begin{array}{l}5-\mathrm{FU} \\
(\mathrm{n}=155)\end{array}$ & $\begin{array}{l}\text { Imiquimod } \\
(n=156)\end{array}$ & $\begin{array}{l}\text { MAL-PDT } \\
(n=156)\end{array}$ & $\begin{array}{l}I M \\
(n=157)\end{array}$ \\
\hline \multicolumn{6}{|l|}{ Location } \\
\hline Vertex & $321(51.4 \%)$ & 78 (50.3\%) & 78 (50.0\%) & 80 (51.3\%) & 85 (54.1\%) \\
\hline Face & $303(48.6 \%)$ & $77(49.7 \%)$ & 78 (50.0\%) & $76(48.7 \%)$ & 72 (45.9\%) \\
\hline \multicolumn{6}{|l|}{ Study site } \\
\hline Maastricht & 247 (39.6\%) & $61(39.4 \%)$ & 62 (39.7\%) & $62(39.7 \%)$ & $62(39.5 \%)$ \\
\hline Eindhoven & $176(28.2 \%)$ & $43(27.7 \%)$ & 44 (28.2\%) & $44(28.2 \%)$ & 45 (28.7\%) \\
\hline Venlo & $108(17.3 \%)$ & $27(17.4 \%)$ & 27 (17.3\%) & 27 (17.3\%) & $27(17.2 \%)$ \\
\hline Heerlen & $93(14.9 \%)$ & $24(15.5 \%)$ & $23(14.7 \%)$ & $23(14.7 \%)$ & $23(14.6 \%)$ \\
\hline
\end{tabular}

Definition of abbreviations: F, female; M, male; IM, ingenol mebutate; 5-FU, 5-fluorouracil; MAL-PDT, methylaminolevulinate photodynamic therapy; AK, actinic keratosis; (N)MSC, (non)melanoma skin cancer;

* There were no significant between-group differences in the characteristics listed here.

** Definition (N)MSC: cutaneous melanoma or keratinocyte cancer

${ }^{* * *}$ Criteria for degree of sun exposure: Mild: no history of frequent sun exposure due to profession, tanning, hobbies; moderate: sun exposure only during leisure time or holidays; severe: outdoor profession, frequent use of solar beds, history of living in tropical areas, water sport).

**** prednisolone, methotrexate, azathioprine, tacrolimus or biologics prior to 3 months before inclusion

A per protocol analysis was based on 555 patients who were treated and had fully adherence to the treatment protocol. A total of 46 patients with initial treatment failure who declined retreatment were excluded. One other patient who requested retreatment with a different therapy was also excluded (Table S1). In the per protocol analysis, data on the eight patients who crossed over were analyzed according to the treatment they actually received. For all treatments, the probability of remaining free from treatment failure was slightly higher in the per protocol population than in the mITT population, but the differences between 5-fluorouracil cream and the other treatments remained significant (Table 2).

A treatment failure after one treatment cycle was observed in $14.8 \%$ of the patients (23 of 155) after 5-fluorouracil therapy, 37.2\% (58 of 156) after imiquimod therapy, 34.6\% (54 of 156) after MAL-PDT, and 47.8\% (75 of 157) after ingenol mebutate therapy. According to the trial protocol, a second treatment cycle was offered to all patients with treatment failure after one cycle. However, some patients declined a second treatment. This occurred more frequently in the imiquimod, MAL-PDT, and ingenol mebutate groups than in the 5-fluorouracil group. Retreatment occurred in 19 of 23 patients (82.6\%) with treatment failure after 5-fluorouracil therapy. These percentages were lower in the other groups: 44 of 58 patients (75.9\%) in the imiquimod group ( $p=0.57$ ), 41 of 54 patients (75.9\%), in the MAL-PDT group ( $p=0.77$ ), and 60 of 75 patients (80.0\%) in the ingenol mebutate group ( $p=1.00)$. 


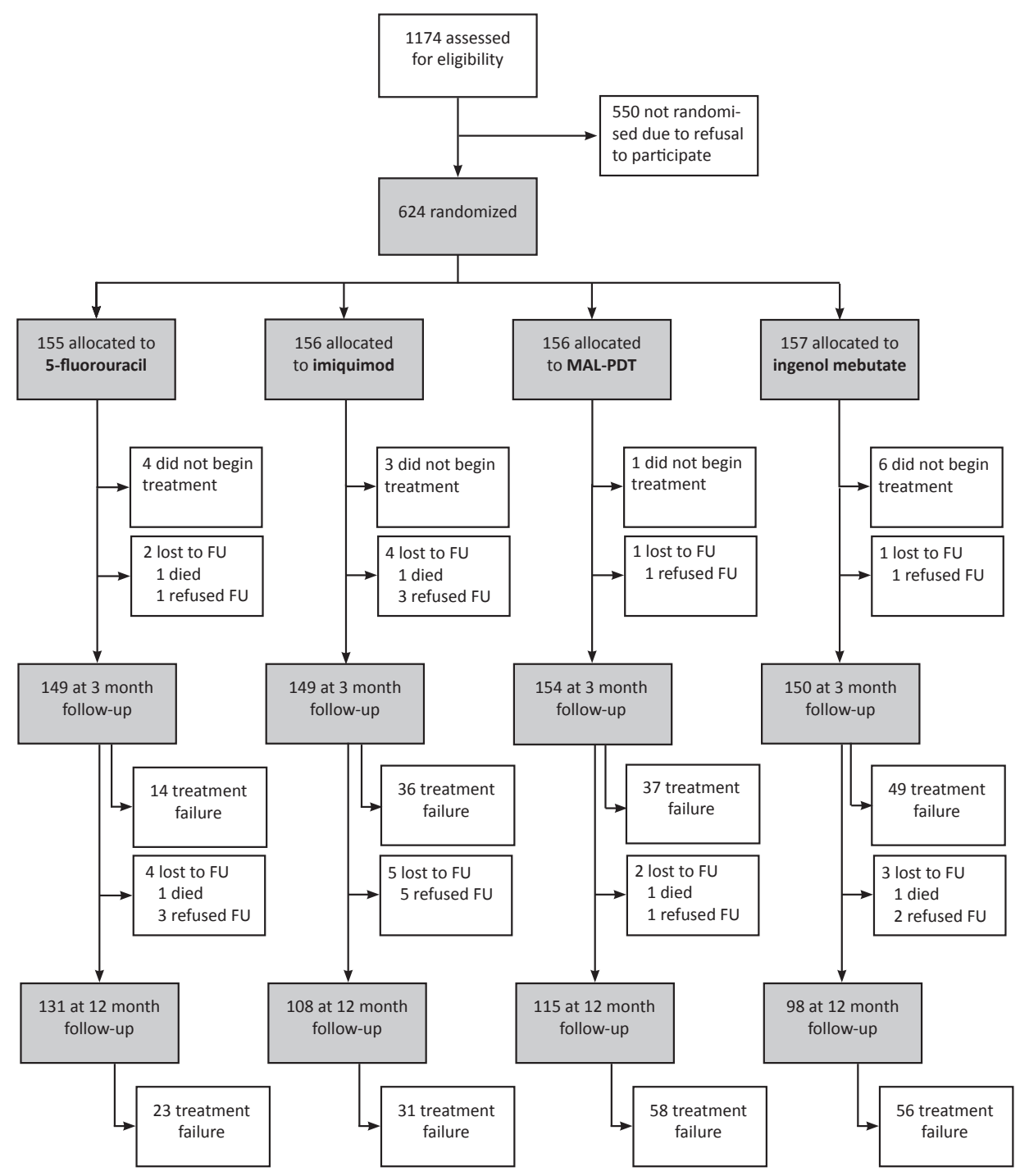

Figure 2. Trial profile, patient flow chart 
When restricting the mITT analysis to patients with grade I and II actinic keratosis, the percentages with treatment success were similar to those in the unrestricted analysis, and 5 -fluorouracil remained superior to the other treatments. For 5 -fluorouracil the percentage was 75.3\% (95\% Cl 67.2-81.7). For imiquimod, PDT, and ingenol mebutate, these percentages were 52.6\% (95\% Cl 43.7-60.7), 38.7\% (95\% Cl 30.7-46.7), and 30.2\% (95\% Cl 22.6-38.1), respectively. The group with grade III actinic keratosis lesions was too small for separate analysis.

\section{Adverse events}

Data on adverse events (from completed patient diaries) were available for 135 patients who received 5-fluorouracil, 121 who received imiquimod, 117 who received MAL-PDT, and 140 received ingenol mebutate. No related serious adverse events occurred. Table 3 shows the percentages of patients who reported adverse events during treatment or the two weeks posttreatment. No patients discontinued the trial because of adverse events.

\section{Other secondary outcomes}

The percentage of patients with 100\% compliance was higher in the ingenol mebutate group (98.7\%) and the MAL-PDT group (96.8\%) than in the 5-fluorouracil group (88.7\%) and the imiquimod group (88.2\%). Patient satisfaction and increase in $\mathrm{HRQOL}$ were highest in the 5-fluorouracil group. Good-excellent cosmetic outcome was more often observed in the MALPDT and ingenol mebutate group (96.6\% and $95.1 \%$, respectively) compared to $90.3 \%$ and $89.7 \%$ in the 5 -fluorouracil and imiquimod group, respectively. Detailed results and $p$-values are provided in the Supplementary Appendix. 


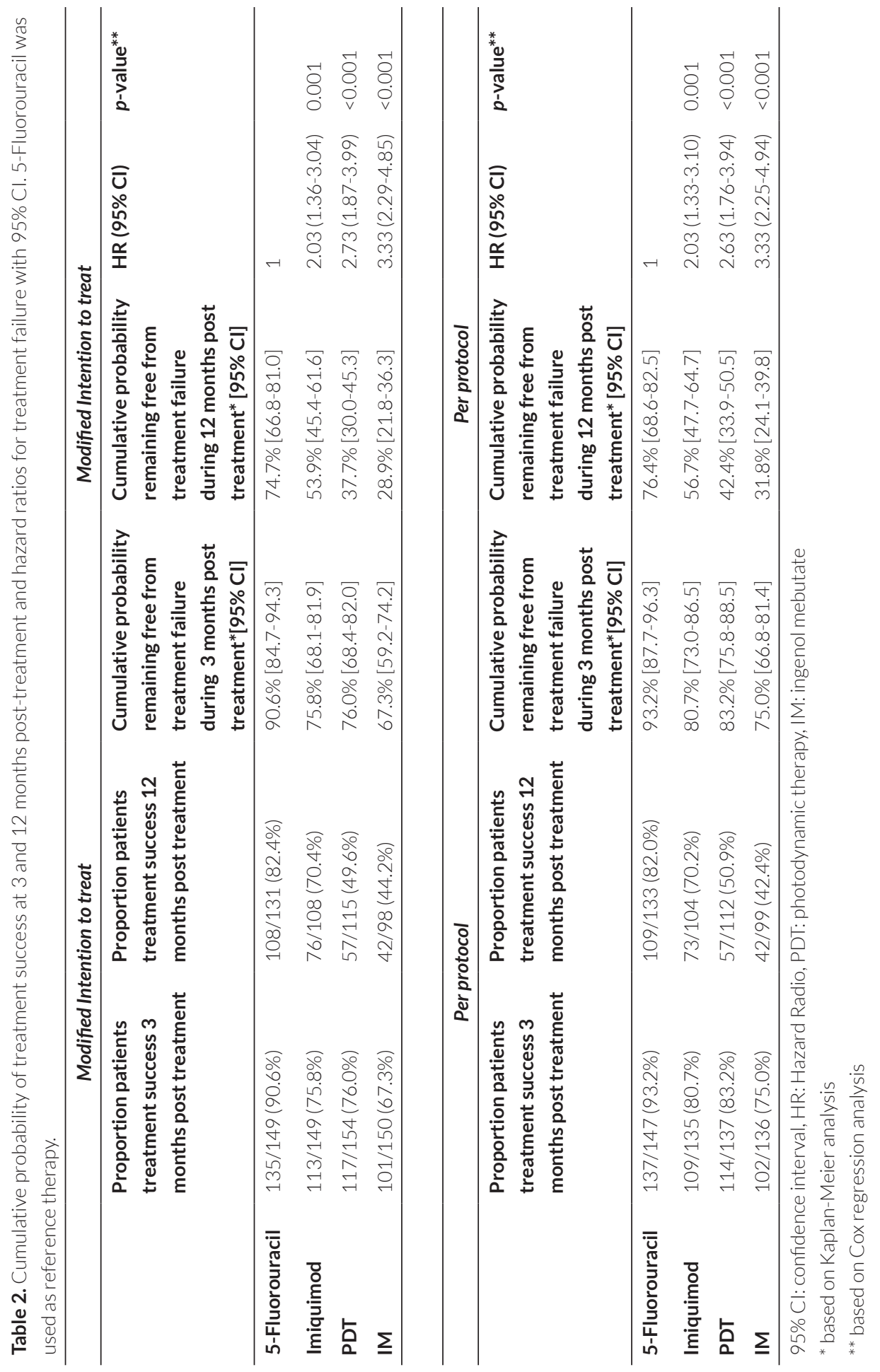


Table 3. Adverse events

\begin{tabular}{|c|c|c|c|c|c|}
\hline & $\begin{array}{c}\text { 5-Fluorouracil } \\
(n=135) \\
n(\%)\end{array}$ & $\begin{array}{c}\text { Imiquimod } \\
(n=121) \\
n(\%)\end{array}$ & $\begin{array}{c}\text { MAL-PDT } \\
(\mathrm{n}=117) \\
\mathrm{n}(\%)\end{array}$ & $\begin{array}{c}\text { IM } \\
(n=140) \\
n(\%)\end{array}$ & $p$-value \\
\hline Any adverse event & $\begin{array}{c}125 / 135 \\
(92.6 \%)\end{array}$ & $\begin{array}{c}103 / 121 \\
(85.1 \%)\end{array}$ & $\begin{array}{c}113 / 117 \\
(96.6 \%)\end{array}$ & $\begin{array}{c}134 / 140 \\
(95.7 \%)\end{array}$ & $0.004^{*}$ \\
\hline \multicolumn{6}{|l|}{ During treatment } \\
\hline Erythema & & & n.a. & & \\
\hline Moderate/Severe & $110(81.5)$ & 88 (72.7) & & $105(75)$ & 0.22 \\
\hline Absent/Mild & $25(18.5)$ & $33(27.3)$ & & $35(25)$ & \\
\hline Swelling & & & n.a. & & \\
\hline Moderate/Severe & $41(30.4)$ & $53(43.8)$ & & $59(42.1)$ & 0.050 \\
\hline Absent/Mild & $94(69.6)$ & $68(56.2)$ & & $81(57.9)$ & \\
\hline Erosion & & & n.a. & & \\
\hline Moderate/Severe & $54(40.0)$ & $58(47.9)$ & & $42(30.0)$ & 0.01 \\
\hline Absent/Mild & $81(60.0)$ & $63(52.1)$ & & $98(70.0)$ & \\
\hline Crusts & & & n.a. & & \\
\hline Moderate/Severe & $77(57.0)$ & $83(68.6)$ & & $53(37.9)$ & $<0.001^{*}$ \\
\hline Absent/Mild & $58(43.0)$ & $38(31.4)$ & & $87(62.1)$ & \\
\hline Vesicles/bullae & & & n.a. & & \\
\hline Moderate/Severe & $33(24.4)$ & $38(31.4)$ & & $59(42.1)$ & $0.007^{*}$ \\
\hline Absent/Mild & $102(75.6)$ & $83(68.6)$ & & $81(57.9)$ & \\
\hline Scaling & & & n.a. & & \\
\hline Moderate/Severe & $60(44.4)$ & $51(42.1)$ & & $50(35.7)$ & 0.31 \\
\hline Absent/Mild & $75(55.6)$ & $70(57.9)$ & & $90(64.3)$ & \\
\hline Itching & & & n.a. & & \\
\hline Moderate/Severe & $84(62.2)$ & 74 (61.2) & & $58(41.4)$ & $0.001^{*}$ \\
\hline Absent/Mild & $51(37.8)$ & $47(38.8)$ & & $82(58.6)$ & \\
\hline \multicolumn{6}{|l|}{ Pain } \\
\hline Severe & $22(16.3)$ & $11(9.1)$ & $73(62.4)$ & $17(12.1)$ & $<0.001^{*}$ \\
\hline Moderate & $21(15.6)$ & $21(17.4)$ & $20(17.1)$ & $40(28.6)$ & \\
\hline Absent/Mild & $92(68.1)$ & $89(73.6)$ & $24(20.5)$ & 83(59.3) & \\
\hline \multicolumn{6}{|l|}{ Burning sensation } \\
\hline Severe & $29(21.5)$ & $12(9.9)$ & $78(66.7)$ & $30(21.4)$ & $<0.001^{*}$ \\
\hline Moderate & $34(25.2)$ & $30(24.8)$ & $22(18.8)$ & $42(30.0)$ & \\
\hline Absent/Mild & $72(53.3)$ & 79 (65.3) & $17(14.5)$ & $68(48.6)$ & \\
\hline
\end{tabular}


Table 3. Continued

\begin{tabular}{|c|c|c|c|c|c|}
\hline & $\begin{array}{c}\text { 5-Fluorouracil } \\
\begin{array}{c}(\mathrm{n}=135) \\
\mathrm{n}(\%)\end{array}\end{array}$ & $\begin{array}{c}\text { Imiquimod } \\
(n=121) \\
n(\%)\end{array}$ & $\begin{array}{c}\text { MAL-PDT } \\
(\mathrm{n}=117) \\
\mathrm{n}(\%)\end{array}$ & $\begin{array}{c}\text { IM } \\
(n=140) \\
n(\%)\end{array}$ & $p$-value \\
\hline \multicolumn{6}{|c|}{ Two weeks post-treatment } \\
\hline \multicolumn{6}{|l|}{ Erythema } \\
\hline Moderate/Severe & $79(58.5)$ & $61(50.4)$ & $87(74.4)$ & $65(46.4)$ & $<0.001^{*}$ \\
\hline Absent/Mild & $56(41.5)$ & $60(49.6)$ & $30(25.6)$ & $75(53.6)$ & \\
\hline \multicolumn{6}{|l|}{ Swelling } \\
\hline Moderate/Severe & $31(23.0)$ & $26(21.5)$ & $29(24.8)$ & $41(29.3)$ & 0.48 \\
\hline Absent/Mild & $104(77.0)$ & $95(78.5)$ & $88(75.2)$ & $99(70.7)$ & \\
\hline \multicolumn{6}{|l|}{ Erosion } \\
\hline Moderate/Severe & 49 (36.3) & $36(29.8)$ & $30(25.6)$ & $30(21.4)$ & 0.045 \\
\hline Absent/Mild & $86(63.7)$ & $85(70.2)$ & $87(74.4)$ & $110(78.6)$ & \\
\hline \multicolumn{6}{|l|}{ Crusts } \\
\hline Moderate/Severe & $66(48.9)$ & $68(56.2)$ & $49(41.9)$ & $87(62.1)$ & $0.008^{*}$ \\
\hline Absent/Mild & $69(51.1)$ & $53(43.8)$ & $68(58.1)$ & $53(37.9)$ & \\
\hline \multicolumn{6}{|l|}{ Vesicles/bullae } \\
\hline Moderate/Severe & $28(20.7)$ & $17(14.0)$ & $22(18.8)$ & $35(25.0)$ & 0.17 \\
\hline Absent/Mild & $107(79.3)$ & $104(86.0)$ & 95 (81.2) & $105(75.0)$ & \\
\hline \multicolumn{6}{|l|}{ Scaling } \\
\hline Moderate/Severe & $77(57.0)$ & $46(38.0)$ & $70(59.8)$ & $93(66.4)$ & $<0.001^{*}$ \\
\hline Absent/Mild & $58(43.0)$ & $75(62.0)$ & $47(40.2)$ & $47(33.6)$ & \\
\hline \multicolumn{6}{|l|}{ Itching } \\
\hline Moderate/Severe & $75(55.6)$ & $47(38.8)$ & $56(47.9)$ & $85(60.7)$ & $0.003^{*}$ \\
\hline Absent/Mild & $60(44.4)$ & $74(61.2)$ & $61(52.1)$ & 55 (39.3) & \\
\hline \multicolumn{6}{|l|}{ Pain } \\
\hline Severe & $9(6.7)$ & $7(5.8)$ & 12 (10.3) & $10(7.1)$ & 0.09 \\
\hline Moderate & $15(11.1)$ & $9(7.4)$ & $21(17.9)$ & 24 (17.1) & \\
\hline Absent/Mild & $111(82.2)$ & $105(86.8)$ & $84(71.8)$ & $106(75.7)$ & \\
\hline \multicolumn{6}{|l|}{ Burning sensation } \\
\hline Severe & 19 (14.1) & $5(4.1)$ & $15(12.8)$ & $8(5.7)$ & 0.01 \\
\hline Moderate & 18 (13.3) & 14 (11.6) & $17(14.5)$ & 32 (22.9) & \\
\hline Absent/Mild & $98(72.6)$ & $102(84.3)$ & $85(72.6)$ & $100(71.4)$ & \\
\hline
\end{tabular}

Definition of abbreviations: MAL-PDT: methylaminolevulinate photodynamic therapy; IM: ingenol mebutate

${ }^{*} p \leq 0.008$ is considered statistically significant 


\section{DISCUSSION}

This trial showed that 5\% 5-fluorouracil is significantly more effective than imiquimod, MALPDT, or ingenol mebutate at 12-months after the end of treatment of multiple actinic keratosis lesions in a continuous area. Findings from the mITT analysis and the per protocol analysis were similar, which indicates robustness of the results.

Although there is substantial literature about different field-direct and lesion-directed treatments, studies often lack head-to-head comparisons, differ substantially in choice of outcome measures, and are underpowered. ${ }^{14,22-24}$ Our randomized clinical trial comparing four field-directed treatments with 12 months of follow-up.

Previously, two network meta-analyses have been published. ${ }^{25,26}$ One meta-analysis, by Vegter and Tolley, indicated that ALA-PDT using BF-200 ALA gel resulted in the highest probability (75.8\%) of total clearance of actinic keratosis lesions, as compared to 0.5\% 5-fluorouracil (59.9\%), 5\% imiquimod (56.3\%) and MAL-PDT (54.8\%) with a follow-up between 3 and 12 months. But this meta-analysis did not include the 5\% 5-fluorouracil, as was used in our trial. ${ }^{25}$ The other meta-analysis, by Gupta and Paquet, suggested that 5\% 5-fluorouracil is the most effective treatment when assessing participant complete clearance. ${ }^{26}$ However, in the 2015 European Dermatology Forum guidelines, the majority of experts did not express a preference for any of the most commonly prescribed treatments. ${ }^{16}$ They agreed that $3.75 \%$ imiquimod, ALA,- or MAL-PDT, ingenol mebutate (0.015/0.050\%) or 0.5\% 5-fluorouracil were equally effective for patients with multiple AK lesions. ${ }^{16}$ However, there was less agreement on the effectiveness of 5\% 5-fluorouracil. In our trial, we used the most commonly prescribed dosing regimens of the therapies studied. Alternative regimens (e.g. different concentrations or duration of therapy) might result in differences in effectiveness between treatments.

An important gap in current literature is that most studies assessing the effectiveness of fielddirected treatments exclude grade III actinic keratosis. In this trial, the population included patients with grade III actinic keratosis lesions; in this way, it is more representative of patients seen in daily practice. Exclusion of grade III actinic keratosis was associated with slightly higher rates of success in 5-fluorouracil, MAL-PDT, and ingenol mebutate groups than the rates in the unrestricted analysis.

The reported adverse events in this study are well known treatment-related side effects that have been described in the corresponding summary of product characteristics. No treatmentrelated serious adverse events occurred. Overall, treatment with 5-fluorouracil was not associated with a higher frequency of adverse events during and after treatment than the other treatments. High scores for pain and burning sensation were reported most often during MAL- 
PDT treatment. Pain can be an important reason for a patient to decline further treatment. In our trial, only $3.2 \%$ of the patients ( 5 of 155 ) in the MAL-PDT group did not complete the entire PDT treatment owing to pain, but the proportion of patients who would undergo this treatment again and would recommend it to others was lower than for the other treatments, which indicates that pain may have influenced patient satisfaction with PDT. Satisfaction with treatment and HRQoL improvement at 12 months after the end of treatment were highest in the 5-fluorouracil group. This may be explained in part by the fact that 5 -fluorouracil was the most effective treatment. However, the high proportion of patients willing to undergo retreatment after initial treatment failure also suggests that patients treated with 5-fluorouracil may have had less inconvenience and discomfort than patients treated with imiquimod, MAL-PDT, or ingenol mebutate, for which the proportions of patients who declined retreatment were higher.

Dermatologists and primary healthcare providers are both confronted with actinic keratosis lesions very frequently. Because of the increasing age of the general population and the high recurrence rate of actinic keratosis, this condition puts a high burden on the healthcare, with 5 million dermatology visits per year in the United States (US) alone. ${ }^{27,28}$ Our results could affect treatment choices in both dermatology and primary care. From a cost perspective, 5-fluorouracil is also the most attractive option. ${ }^{29}$ It is expected that a substantial cost-reduction can be achieved with more uniformity in care and the choice for the most effective therapy.

This randomized trial has some limitations. Approximately half the patients who were assessed for eligibility declined to participate in this trial, usually because of personal preference or disfavor for a specific therapy. Declining to participate is a common problem in randomized trials and may threaten external validity. The median age of the eligible trial population, 75 years, was similar to that of patients who participated, but the ratio of men to women was $4: 1$ in the eligible population and 9:1 in the trial population, which suggests that men were more willing to participate. Generalizability of the findings would be affected if effectiveness of the evaluated treatments depends on sex, but sex-specific treatment response seems unlikely. To avoid substantial inter-observer variability, all counts were performed by one single observer blinded to the treatment. There may still be intra-observer variability, but random measurement errors result in nondifferential misclassification, which tends to dilute differences between baseline and follow-up counts of actinic keratosis lesions. However, potential underestimation of the reduction in actinic keratosis lesions will occur in all treatment groups and is unlikely to affect the comparison between groups..$^{30}$ Compliance to therapy with 5-fluorouracil and imiquimod, which are applied for 4 consecutive weeks, was high in this trial (88.7\% and 88.2\%, respectively), but in daily practice, compliance may be lower. In this respect, ingenol mebutate, which has to be applied for only 3 consecutive days, had the advantage of better compliance (98.7\%), but owing to the observed low probability of remaining free from treatment failure of only $28.9 \%$ in the long term, ingenol mebutate might be reserved for situations where alternative treatments are not feasible. 
In our trial, compliance was assessed by asking patients two weeks after the end of treatment how often they used the therapy. This method may be subject to error.

In conclusion, we found that after 12 months follow-up 5\% 5-fluorouracil cream was significantly more effective than 5\% imiquimod cream, MAL-PDT, and $0.015 \%$ ingenol mebutate gel in the treatment of patients with multiple grade I-III actinic keratosis in the head and neck area. No new toxic effects were identified in this trial.

\section{FUNDING}

The study was financed by a grant of the Netherlands Organization for Scientific Research ZonMW (80-83600-98-3054). ZonMw is a governmental institution financing research to improve health care in the Netherlands.

\section{ACKNOWLEDGEMENTS}

We thank the patients who agreed to participate in this study. We thank all nurse practitioners, nursing staff and employees of the administrative departments of the participating hospitals. We are especially thankful for the effort that the following persons attributed to our study: Drs. S. Dodemont, Drs. L. Voeten, Drs. M. Hacking, Drs. J. Clabbers, Drs. N. Ramakers, Drs. M. Maris, Drs. E. van Loo, Drs. J. Havens, Drs. S. Ahmady and Mrs. A. Ebus M ANP. 


\section{REFERENCES}

1. Flohil SC, van der Leest RJ, Dowlatshahi EA, Hofman A, de Vries E, Nijsten T. Prevalence of actinic keratosis and its risk factors in the general population: the Rotterdam Study. The Journal of investigative dermatology. 2013;133(8):1971-1978.

2. Spencer JM, Hazan C, Hsiung SH, Robins P. Therapeutic decision making in the therapy of actinic keratoses. Journal of drugs in dermatology: JDD. 2005;4(3):296-301.

3. Siegel JA, Korgavkar K, Weinstock MA. Current perspective on actinic keratosis: a review. The British journal of dermatology. 2017;177(2):350-358.

4. Dinehart SM, Nelson-Adesokan P, Cockerell C, Russell S, Brown R. Metastatic cutaneous squamous cell carcinoma derived from actinic keratosis. Cancer. 1997;79(5):920-923.

5. Ackerman AB, Mones JM. Solar (actinic) keratosis is squamous cell carcinoma. The British journal of dermatology. 2006;155(1):9-22.

6. Marks R, Rennie G, Selwood TS. Malignant transformation of solar keratoses to squamous cell carcinoma. Lancet. 1988;1(8589):795-797.

7. Lanoue J, Chen C, Goldenberg G. Actinic keratosis as a marker of field cancerization in excision specimens of cutaneous malignancies. Cutis. 2016;97(6):415-420.

8. Glogau RG. The risk of progression to invasive disease. Journal of the American Academy of Dermatology. 2000;42(1 Pt 2):23-24.

9. Criscione VD, Weinstock MA, Naylor MF, Luque C, Eide MJ, Bingham SF. Actinic keratoses: Natural history and risk of malignant transformation in the Veterans Affairs Topical Tretinoin Chemoprevention Trial. Cancer. 2009;115(11):2523-2530.

10. Frost C, Williams $\mathrm{G}$, Green A. High incidence and regression rates of solar keratoses in a queensland community. The Journal of investigative dermatology. 2000;115(2):273-277.

11. Pomerantz H, Hogan D, Eilers D, et al. Long-term Efficacy of Topical Fluorouracil Cream, 5\%, for Treating Actinic Keratosis: A Randomized Clinical Trial. JAMA dermatology. 2015;151(9):952-960.

12. Weinstock MA, Thwin SS, Siegel JA, et al. Chemoprevention of Basal and Squamous Cell Carcinoma With a Single Course of Fluorouracil, 5\%, Cream: A Randomized Clinical Trial. JAMA dermatology. 2018.

13. Neugebauer R, Levandoski KA, Zhu Z, et al. A real-world, community-based cohort study comparing the effectiveness of topical fluoruracil versus topical imiquimod for the treatment of actinic keratosis. Journal of the American Academy of Dermatology. 2018;78(4):710-716.

14. de Berker D, McGregor JM, Mohd Mustapa MF, Exton LS, Hughes BR. British Association of Dermatologists' guidelines for the care of patients with actinic keratosis 2017. The British journal of dermatology. 2017;176(1):20-43.

15. Beljaards RC, van der Sande A. . Update richtlijn actinische keratosen 2017. Nederlands Tijdschrift voor Dermatologie en Venereologie. 2017;27 190-192.

16. Werner RN, Stockfleth E, Connolly SM, et al. Evidence- and consensus-based (S3) Guidelines for the Treatment of Actinic Keratosis - International League of Dermatological Societies in cooperation with the European Dermatology Forum - Short version. Journal of the European Academy of Dermatology and Venereology: JEADV. 2015;29(11):2069-2079.

17. Gupta AK, Paquet M, Villanueva E, Brintnell W. Interventions for actinic keratoses. The Cochrane database of systematic reviews. 2012;12:Cd004415.

18. Pocock SJ, Simon R. Sequential treatment assignment with balancing for prognostic factors in the controlled clinical trial. Biometrics. 1975;31(1):103-115. 
19. Olsen EA, Abernethy ML, Kulp-Shorten C, et al. A double-blind, vehicle-controlled study evaluating masoprocol cream in the treatment of actinic keratoses on the head and neck. Journal of the American Academy of Dermatology. 1991;24(5 Pt 1):738-743.

20. Nijsten T, Sampogna F, Abeni D. Categorization of Skindex-29 scores using mixture analysis. Dermatology (Basel, Switzerland). 2009;218(2):151-154.

21. Lebwohl M, Dinehart S, Whiting D, et al. Imiquimod $5 \%$ cream for the treatment of actinic keratosis: results from two phase III, randomized, double-blind, parallel group, vehicle-controlled trials. Journal of the American Academy of Dermatology. 2004;50(5):714-721.

22. Dirschka T, Gupta G, Micali G, et al. Real-world approach to actinic keratosis management: practical treatment algorithm for office-based dermatology. The Journal of dermatological treatment. 2017;28(5):431-442.

23. Stockfleth E, Ferrandiz C, Grob JJ, Leigh I, Pehamberger H, Kerl H. Development of a treatment algorithm for actinic keratoses: a European Consensus. Eur J Dermatol. 2008;18(6):651-659.

24. Stockfleth E, Kerl H. Guidelines for the management of actinic keratoses. European journal of dermatology: EJD. 2006;16(6):599-606.

25. Vegter S, Tolley K. A network meta-analysis of the relative efficacy of treatments for actinic keratosis of the face or scalp in Europe. PloS one. 2014;9(6):e96829.

26. Gupta AK, Paquet M. Network meta-analysis of the outcome 'participant complete clearance' in nonimmunosuppressed participants of eight interventions for actinic keratosis: a follow-up on a Cochrane review. The British journal of dermatology. 2013;169(2):250-259.

27. Kirby JS, Gregory T, Liu G, Leslie DL, Miller JJ. Variation in the Cost of Managing Actinic Keratosis. JAMA dermatology. 2017;153(4):264-269.

28. Gupta AK, Cooper EA, Feldman SR, Fleischer AB, Jr. A survey of office visits for actinic keratosis as reported by NAMCS, 1990-1999. National Ambulatory Medical Care Survey. Cutis. 2002;70(2 Suppl):8-13.

29. Medicijnkosten. www.medicijnkosten.nl, 12 September 2017.

30. Rothman KJ, Lash TL, Greenland S. Modern Epidemiology 3rd ed: Lippincott Williams And Wilkins; 2012. 


\section{SUPPLEMENTARY APPENDIX METHODS}

This multi-centre single blinded randomized study was conducted at dermatology departments of four hospitals in the Netherlands (Maastricht University Medical Centre (MUMC+, coordinating center), Zuyderland Medical Centre Heerlen (ZMC), VieCuri Medical Centre Venlo/Venray (VMC), and the Catharina Hospital Eindhoven (CHE).

The trial was designed by JK, PN, BE, NK-S, and KM. The data were collected and analyzed by MJ, $J K, P N, B E$, and KM. All authors wrote the manuscript. The authors vouch for the completeness and accuracy of the data and analyses and for the fidelity of the trial to the protocol.

The trial is registered on clinicaltrials.gov (NCT02281682).

The severity of each lesion was graded with the Olsen scale: $1=$ mild, $2=$ moderate or $3=$ severe. ${ }^{1}$

Randomization lists, based on minimization, were computer generated with ALEA software (ALEA version 2.2, Amsterdam, the Netherlands). ${ }^{2}$

\section{Treatment protocols}

PDT treatment was performed by trained nurses who applied a thin ( $1 \mathrm{~mm}$ ) layer of MAL cream (Metvix ${ }^{\circledR}$, Galderma SA, Penn Pharmaceutical Services, Gwent, UK) to the treatment area, followed by coverage with light blocking aluminum foil and occlusive dressing (Tegaderm $\AA$, $3 \mathrm{M}$, Leiden, the Netherlands) for 3 hours. Consecutively, the area was illuminated with a light emitting diode (LED): Aktilite $®$ (Galderma, SA, Lausanne, Switzerland) or Omnilux $®$ (Waldmann phototherapeutics, London, UK) with an optimum wavelength of $635 \pm 18 \mathrm{~nm}$ (fluence $37 \mathrm{~J} /$ $\mathrm{cm}^{2}$ during 7.23 minutes). Directly after illumination the treatment area was covered up for 24 hours. Per $25 \mathrm{~cm}^{2}$ of treatment area, 2 grams of MAL cream were used.

IM 0.015\% gel (Picatoß, LEO Pharma A/S, Bellerup, Denmark) was applied by the patient once daily for 3 consecutive days. Per $25 \mathrm{~cm}^{2}$ of treatment area, one tube (0.47 gram) per day was used.

The 5\% imiquimod cream (Aldara ${ }^{\circledR}$, Meda Pharma B.V., Solna, Sweden) was self-applied once daily, 3 days a week (Monday-Wednesday-Friday), for 4 consecutive weeks. Per area of $25 \mathrm{~cm}^{2}$ one sachet of $250 \mathrm{mg}$ was used per day.

5\% 5-Fluorouracil cream (Efudix $®$, Meda Pharma B.V., Amstelveen, the Netherlands) was selfapplied twice daily for 4 weeks. Each patient received one tube of 40 grams independent of the treatment area size. 


\section{Secondary outcomes}

Patients were asked to complete detailed diaries to obtain information about adverse events, during and two weeks post-treatment. Pain and burning sensation were recorded using a Numeric Rating Scale (NRS) ranging from 0 (no pain) to 10 (unbearable pain) and categorized into absent/mild (0.0-3.0), moderate (3.1-6.0) or severe (6.1-10.0). Patientreported adverse events such as erythema, swelling, erosion, crusting, appearing of vesicles/ bullae, scaling and itching were obtained through the diary, using a 4-point scale $(\mathrm{O}=$ =absent, 1=mild, 2=moderate, 3 =severe) and were categorized into absent/mild and moderate/ severe. For analysis, the maximum scores recorded during or post-treatment were used. Compliance was defined as the proportion of patients who used the cream/gel every day as prescribed. This information was retrieved by telephone consultation two weeks after treatment by the investigator not blinded to treatment allocation (JK). Any cessation of therapy was recorded.

Patient satisfaction with treatment was assessed at 3 and 12 months post-treatment questioning patients whether they would undergo the same treatment again and whether they would recommend it to other patients. Furthermore, HRQOL was assessed by completing the Skindex-29 at baseline, 3 and 12 months post-treatment. The Skindex-29 has a range 0-100 and lower scores indicate better HRQoL. ${ }^{3}$

At 12 months post-treatment, cosmetic outcome was evaluated using a 4 point scale ( 1 =excellent, $2=$ good, $3=$ moderate and 4=poor), by the physician blinded to treatment allocation who also recorded whether erythema or pigmentation change was present.

\section{RESULTS}

\section{Compliance}

The percentage of patients with 100\% compliance was the highest in the IM group. For the IM group, this percentage was 98.7\% (149/151), for 5-fluorouracil 88.7\% (134/151), for imiquimod 88.2\% (135/153), and for MAL-PDT 96.8\% (150/155). The differences between IM versus 5 -fluorouracil and PDT versus 5-fluorouracil were statistically significant ( $p=0.001$ and $p=0.007$, respectively). In the MAL-PDT group, illumination was stopped prematurely in 5 patients due to pain. These patients were considered as non-compliant.

\section{Patient satisfaction}

Twelve months post-treatment more patients with 5-fluorouracil answered they were willing to undergo retreatment if necessary $(86.2 \%, 125 / 145)$ and would recommend the same treatment (93.1\%, 135/145) compared to patients treated with imiquimod (75.0\%, 102/137; $p=0.016$ and 
81.0\%, 111/137; $p=0.004)$, PDT (60.4\%, 90/149; $p=<0.001$ and 70.3\%, 104/148; $p=<0.001)$, and IM (75.7\%, 109/144; $p=0.025$ and $84.7 \%, 122 / 144 ; p=0.025)$.

\section{HRQoL}

At 12 months post-treatment, the median decrease in Skindex-29 score from baseline was compared between treatment groups. The median decrease was -4.31 (-30.2-31.9) for 5-fluorouracil, -3.88 (-54.3-37.9) for imiquimod, -2.59 (-31.9-15.5) for MAL-PDT, and -3.45 (-37.9-27.6) for IM. A larger decrease in Skindex-29 score represents more improvement in HRQoL. P-values comparing 5-fluorouracil with imiquimod, MAL-PDT, and IM were $p=0.68$, $p=0.002$, and $p=0.20$, respectively.

\section{Cosmetic results}

Twelve months post-treatment a good-excellent cosmetic result was found in 90.3\% (130/144) patients treated with 5-fluorouracil, in 89.7\% (122/136), 96.6\% (144/149) and 95.1\% (137/144) of the patients treated with imiquimod, PDT and IM, respectively. Percentages were highest for PDT and IM, the difference between 5-fluorouracil and MAL-PDT was significant ( $p=0.033$ ), whereas the difference between 5-fluorouracil and imiquimod and 5-fluorouracil and IM was not significant ( $p=1.00$ and $p=0.173$, respectively). The proportion of patients with erythema, as assessed by the investigator, was lowest in patients treated with 5 -fluorouracil $(22.9 \%$, 33/144) compared to the other treatments: imiquimod (35.3\%, 48/136), PDT (30.2\%, 45/149) and IM (30.6\%, 44/144). Pigmentation change, assessed by the investigator was most often observed after treatment with imiquimod (45.6\%, 62/136), but also occurred rather frequently after treatment with 5-fluorouracil (43.1\%, 62/144), PDT (39.6\%, 59/149) and IM (38.2\%, $55 / 144)$. In the majority of patients with pigmentation change the most predominant feature was hypopigmentation (87.0\%, 207/238), followed by hyperpigmentation $(7.6 \%, 18 / 238)$ or a combination of hypo- and hyperpigmentation (5.5\%, 13/238).

Table S1. Development of analysis datasets. Sample size (number of failures) for the intention-to-treat (ITT), modified intention-to-treat ( $\mathrm{mITT}$ ), and per protocol (PP) population.

\begin{tabular}{lcccc}
\hline & 5-fluorouracil & Imiquimod & PDT & Ingenol mebutate \\
\hline ITT population $\mathrm{n}=624$ & 155 & 156 & 156 & 157 \\
mITT population $\mathrm{n}=602$ & $149(37)^{*}$ & $149(67)^{*}$ & $154(95)^{*}$ & $150(105)^{*}$ \\
PP population $\mathrm{n}=555$ & $147(34)^{*}$ & $135(57)^{*}$ & $137(78)^{*}$ & $136(91)^{*}$ \\
\hline
\end{tabular}

The intention-to-treat (ITT) population was defined as the sample of patients who were randomized. The modified intention-to-treat (mITT) population included patients who were randomized and received treatment and for whom the primary outcome was available. The per protocol (PP) population consisted of a subset of patients who fully adhered to the treatment protocol. 


\section{REFERENCES}

1. Olsen EA, Abernethy ML, Kulp-Shorten C, et al. A double-blind, vehicle-controlled study evaluating masoprocol cream in the treatment of actinic keratoses on the head and neck. Journal of the American Academy of Dermatology. 1991;24(5 Pt 1):738-743.

2. Pocock SJ, Simon R. Sequential treatment assignment with balancing for prognostic factors in the controlled clinical trial. Biometrics. 1975;31(1):103-115.

3. Nijsten T, Sampogna F, Abeni D. Categorization of Skindex-29 scores using mixture analysis. Dermatology (Basel, Switzerland). 2009;218(2):151-154. 


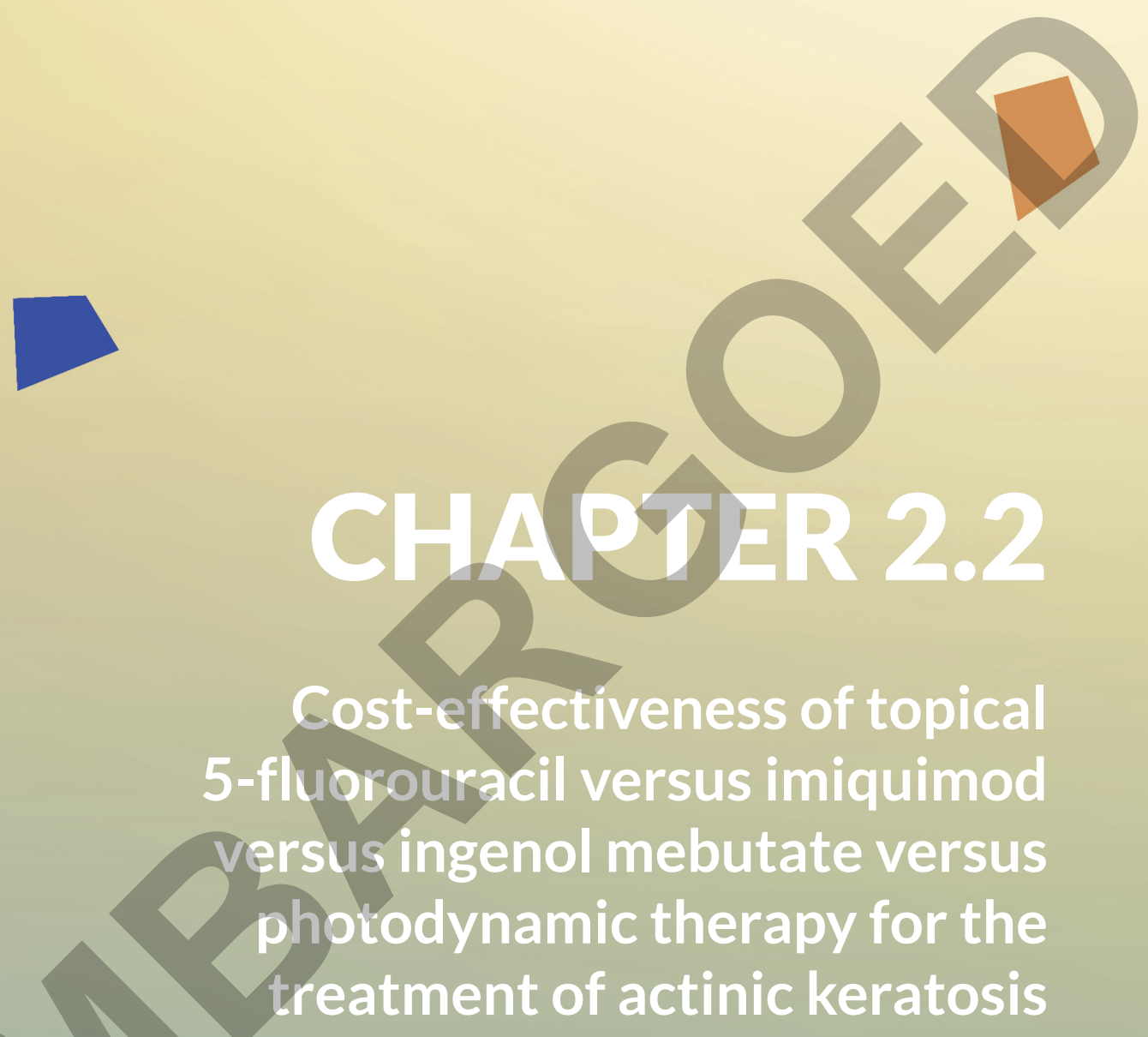

M.H.E. Jansen, J.P.H.M. Kessels, I. Merks, P.J. Nelemans, N.W.J. Kelleners-Smeets, K. Mosterd*, B.A.B. Essers* 

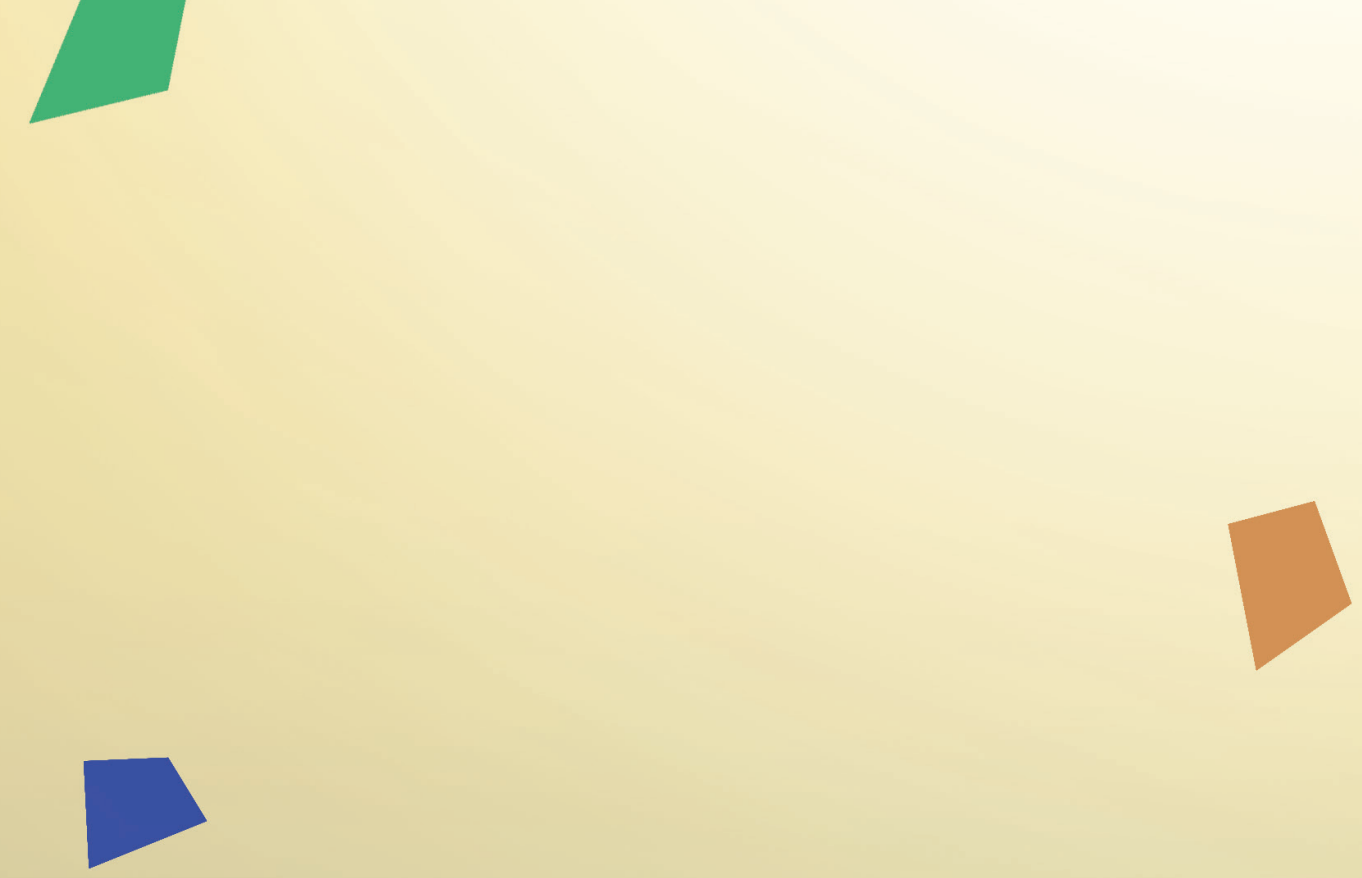

\section{CHAPTER 3}

Bowen's disease 


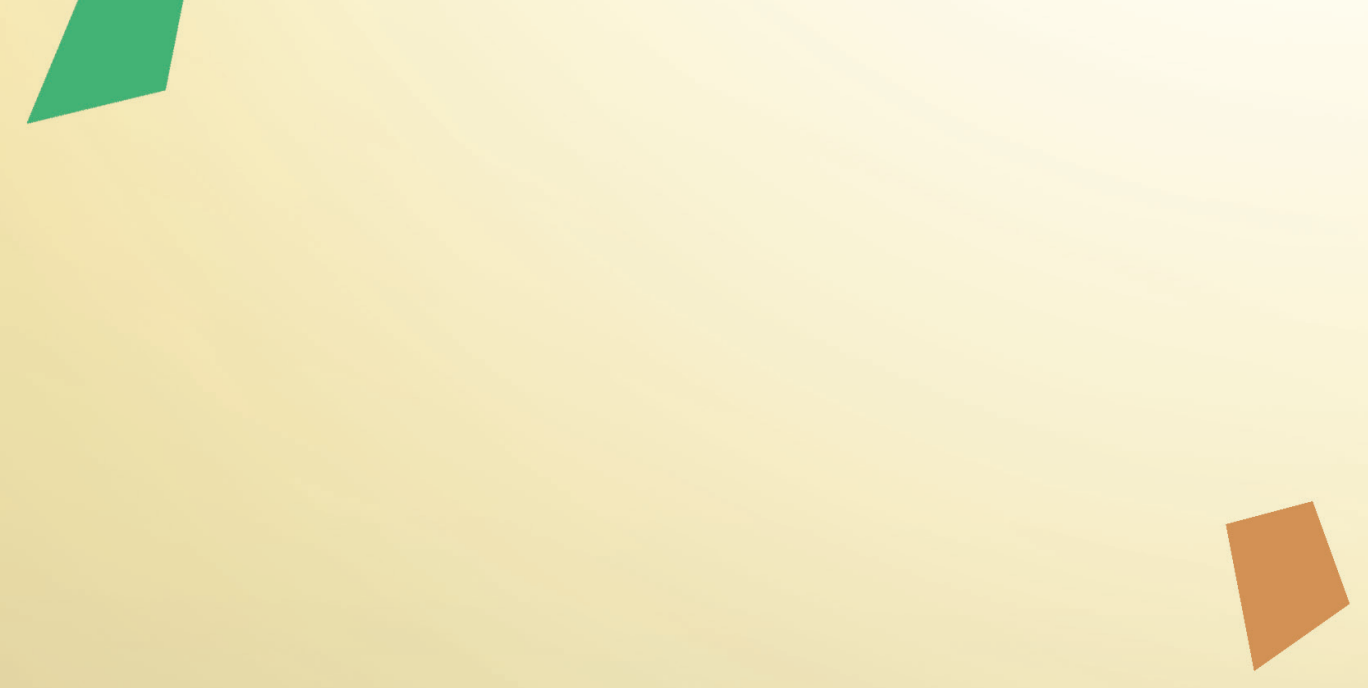

\section{CHAPTER 3.1}

Trends in the incidence of Bowen's disease based on a single centre study in the Netherlands

M.H.E. Jansen, H. Özhan-Hasan, P.J. Nelemans, V.J. Winnepenninckx, N.W.J. Kelleners-Smeets, K. Mosterd 


\section{ABSTRACT}

\section{Background}

Incidence trends of non-melanoma skin cancer show an increase. Few data have been published about the incidence of Bowen's disease (BD). Three previous studies, conducted more than 15 years ago in North America, found large variation in incidence rates in Caucasians and trends over longer periods have never been studied.

\section{$\underline{\text { Objective }}$}

To estimate the incidence of BD in a Caucasian population in Northern Europe (Maastricht, the Netherlands) between 2003 and 2013.

\section{Methods}

Primary and histologically confirmed BD, diagnosed in Maastricht, the Netherlands in the years 2003, 2008 and 2013, were retrieved from a pathology database. Age-standardized and genderspecific incidence rates per 100,000 inhabitants were calculated by using the age distribution of the European standard population of 2013.

\section{$\underline{\text { Results }}$}

A statistically significant increase in the annual age-standardized incidence rates per 100,000 people was found from 8.1 (95\% confidence interval (Cl) 3.7-12.5) in 2003 to 68.9 (95\% Cl $57.2-80.7)$ in $2013(p<0.001)$. For women, there was an increase from $7.7 / 100,000(95 \% \mathrm{Cl}$ 2.0-13.4) in 2003 to $76.8 / 100,000$ (95\% Cl 60.2-93.5) in 2013, respectively ( $p<0.001)$. An increase from 8.8/100,000 (95\% Cl 1.8-15.9) in 2003 to 59.2/100,000 men (95\% Cl 42.8-75.6) in $2013(p<0.001)$ was found.

\section{Conclusion}

These findings suggest an increase in the annual age-standardized incidence rates in BD. 


\section{INTRODUCTION}

Non-melanoma skin cancer is the most common malignancy in Caucasian populations. ${ }^{1}$ A recent systematic review reported rising incidence trends in basal cell carcinoma (BCC) and squamous cell carcinoma (SCC) worldwide. ${ }^{1}$ In contrast to these two most common forms of non-melanoma skin cancer, only few data have been published on the incidence of Bowen's disease (BD).

BD is a cutaneous intra-epithelial SCC in situ, which was first described in 1912 by JT Bowen. ${ }^{2}$ A low risk for progression to SCC is reported. ${ }^{3,4}$ Only a very few studies report on incidence rates of BD in Caucasians. To date, estimates of the incidence rates largely come from studies in the United States, which were conducted more than 20 years ago and showed large variation with 10 -fold differences in incidence rates. ${ }^{5,6} \mathrm{~A}$ more recent study reported an average annual incidence of 22.4 and 27.8/100,000 in female and male Canadian residents respectively in the period between 1996 and 2000. ${ }^{7}$ Variation in the reported incidence of BD can be explained by the differences in sun exposure of the studied population groups due to differences in latitude and climate between the regions where the studies were conducted. The divergence in incidence rates stresses the importance of representative climate conditions when drawing conclusions about the incidence of BD.

To the best of our knowledge, there are no studies that estimate the incidence and incidence trends of $\mathrm{BD}$ in the Caucasian population living in Europe and consequently up-to-date and representative figures for the incidence trend of BD in Europe are lacking. Information about these trends are important for health care planning.

Here, we present the incidence and incidence trends of BD in a Caucasian population in Northern Europe.

\section{METHODS}

Estimates of BD incidence and trends in incidence over time are based on a retrospective study using data from a pathology registry and the corresponding electronic patient files of the Maastricht University Medical Centre (MUMC+) in the Netherlands. The MUMC+ is the only hospital in the district of Maastricht and a tertiary referral hospital for dermato-oncology in the Netherlands.

\section{Data}

All patients with a primary BD diagnosed in 2003, 2008 and 2013 in the MUMC+ were retrospectively identified through the PALGA (Pathologisch-Anatomisch Landelijk Geautomatiseerd Archief) database, an electronic archive recording all pathological diagnoses 
made by affiliated pathology departments. The search terms used were "Bowen's disease" or "Bowen" or "carcinoma in situ" combined with topography "skin". The full pathology reports and the medical records were reviewed by one investigator. Included were patients living in the district of Maastricht with a histopathologically confirmed BD diagnosed by biopsy or excision. Only one BD per patient was included in this study, which is defined as the first BD in the studied periods. Each subsequent BD in the same patient was excluded. Also excluded were tumours with anogenital localization, recurrent tumours and lesions that included other malignancies in the biopsy or the excision. Patients from other geographical areas than the district of Maastricht or slides, which were sent from other laboratories to our hospital for second opinion, were excluded. We excluded patients from other geographical areas because we matched the data retrieved from the PALGA with clinical information: patient and tumour characteristics were obtained from the pathology reports and the (electronic) patient reports. Recorded were age of onset, sex, tumour localization, size of the tumour and chronic use of immunosuppressive drugs. For tumour size, the largest clinically recorded diameter in millimetres was used. To exclude a shift in the definition of BD, a PALGA search was performed to obtain the number of lesions within the spectrum of BD (actinic keratosis (AK) and SCC), for 2003, 2008 and 2013.

\section{Statistical analysis}

Age- and sex specific incidence rates per 100,000 inhabitants in the district of Maastricht were calculated using five-year groups. Data about the age and gender distribution of the population of the district of Maastricht were derived from the Dutch Central Bureau of Statistics. ${ }^{8}$ The age distribution of the European standard population of 2013 was used for calculation of age standardized incidence rates with an Excel template from the UK National Office for Statistics. Trend over time was tested for statistical significance by using the chi square test for trend in proportions.

For descriptive purposes, tumour and patient characteristics are presented as numbers and percentages for categorical variables and as mean ( \pm standard deviation) or median with range for continuous variables. The distribution of variables in the years 2003, 2008 and 2013 were compared and differences were tested for significance using the chi square test for proportions and analysis of variance (ANOVA) or the non-parametric Kruskall-Wallis test for continuous variables. Analyses were performed using SPSS version 23.0 (IBM Corp., Armonk, NY, USA) or $R$ version 2.15.1. ${ }^{10} \mathrm{~A}$ P-value $\leq 0.05$ was considered to indicate statistical significance. 


\section{RESULTS}

The search in the PALGA database for "Bowen's Disease" or "Bowen" or "carcinoma in situ" combined with topography "skin" resulted in 677 records. As illustrated in Figure 1, excluded were double records coding for one tumour (e.g. biopsy and excision) (186 records), patients with missing data (20 records), tumours diagnosed in the previous year (10 records), tumours which were wrongly labelled with the diagnosis BD (102 records), tumours which were located in the anogenital region (14 records), recurrent tumours (14 records), slides of patients from geographical areas outside the district of Maastricht (90 records) and records of subsequent tumours from patients who were already included in the study (20 records).

In total, 221 primary and histologically confirmed BDs were retrieved from the PALGA database: 13 patients in 2003, 76 patients in 2008 and 132 patients in 2013.

Patient and tumour characteristics are presented in Table 1. The majority of the patients were female and most of the tumours were located in the sun-exposed areas (head and neck region and extremities). No statistical difference in sex, age and localisation of the tumour between the three year groups was found. A statistically significant decrease was observed with respect to the proportion of immunocompromised patients ( $p<0.001$ ) between 2003, 2008 and 2013. A trend towards decrease of the median maximal tumour size was observed, from 10mm in 2003 and 2008 to $8 \mathrm{~mm}$ in 2013 ( $p=0.06$ ).

\section{Incidence and incidence trend}

The absolute number of patients with a histologically confirmed first BD in the district of Maastricht increased from 13 in 2003 to 76 in 2008 and to 132 in 2013. For women, a statistically significant increase in annual age-standardized incidence rates per 100,000 was observed from 7.7 (95\% confidence interval (CI) 2.0-13.4) in 2003 to 56 (95\% Cl 41.3-70.7) and 76.8 (95\% Cl 60.2-93.5) in 2008 and 2013 respectively ( $p<0.001)$. Also a significant increase of the annual age-standardized incidence rates per 100,000 men was observed from 8.8 (95\% Cl 1.8-15.9) in 2003, 26.1 (95\% Cl 14.6-37.5) in 2008 to 59.2 (95\% Cl 42.8-75.6) in 2013 ( $p<0.001)$. For both sexes combined, the annual age-standardized incidence rates per 100,000 inhabitants increased significantly from 8.1 (95\% Cl 3.7-12.5) in 2003 to 44.9 (95\% Cl 34.8-54.9) in 2008 and to 68.9 (95\% Cl 57.2-80.7) in 2013 ( $p<0.001)$. Trends are visualized in Figure 2. 


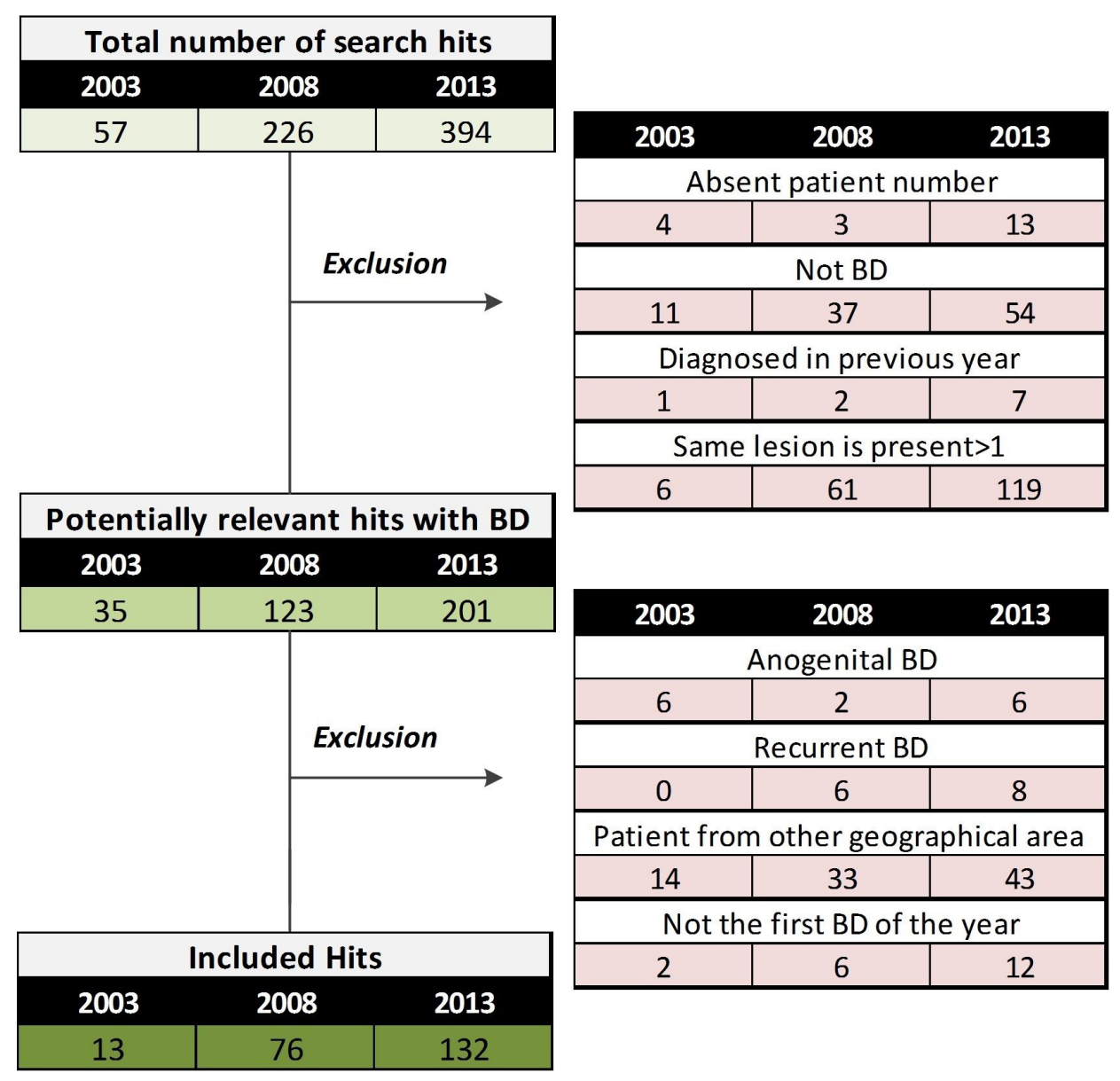

Figure 1. Overview of search records from PALGA database in Maastricht for "Bowen's disease" or "Bowen" or "carcinoma in situ" combined with "skin" for the years 2003, 2008 and 2013 and the selection of valid records. 
Table 1. Patient and tumour characteristics of included patients.

\begin{tabular}{|c|c|c|c|c|c|c|}
\hline Characteristics & Value & Total & 2003 & 2008 & 2013 & $p$-value \\
\hline Patient characteristics & & $N=221$ & $N=13$ & $N=76$ & $N=132$ & \\
\hline \multirow[t]{2}{*}{ Sex } & Female (n, \%) & $145(65.6)$ & $7(53.8)$ & $56(73.7)$ & $82(62.1)$ & \multirow[t]{2}{*}{$0.18^{*}$} \\
\hline & Male (n, \%) & $76(34.4)$ & $6(46.2)$ & $20(26.3)$ & $50(37.9)$ & \\
\hline Age at diagnosis & $\begin{array}{l}\text { Years } \\
\text { (median, range) }\end{array}$ & $\begin{array}{l}77 \\
{[40-95]}\end{array}$ & $\begin{array}{l}73 \\
{[48-83]}\end{array}$ & $\begin{array}{l}77.5 \\
{[40-95]}\end{array}$ & $\begin{array}{l}76 \\
{[43-93]}\end{array}$ & $0.47^{* *}$ \\
\hline \multirow[t]{3}{*}{$\begin{array}{l}\text { Immunosuppressive } \\
\text { medication }\end{array}$} & No (n, \%) & $196(88.7)$ & $7(53.8)$ & $69(90.8)$ & $\begin{array}{l}120 \\
(90.9)\end{array}$ & \multirow[t]{3}{*}{$<0.001^{*}$} \\
\hline & Yes (n, \%) & $22(10)$ & $6(46.2)$ & $5(6.6)$ & $11(8.3)$ & \\
\hline & Unknown (n, \%) & $3(1.4)$ & 0 & $2(2.6)$ & $1(0.8)$ & \\
\hline \multicolumn{7}{|l|}{ Tumour characteristics } \\
\hline \multirow[t]{5}{*}{ Tumour location } & $\begin{array}{l}\text { Head neck } \\
\text { region (n, \%) }\end{array}$ & $82(37.1)$ & $5(38.5)$ & $27(35.5)$ & $50(37.9)$ & \multirow[t]{5}{*}{$0.08^{*}$} \\
\hline & $\begin{array}{l}\text { Upper extremi- } \\
\text { ties }(n, \%)\end{array}$ & $48(21.7)$ & $6(46.2)$ & $12(15.8)$ & $30(22.7)$ & \\
\hline & $\begin{array}{l}\text { Lower extremi- } \\
\text { ties }(n, \%)\end{array}$ & $53(24)$ & $2(15.4)$ & $25(32.9)$ & $26(19.7)$ & \\
\hline & Trunk (n, \%) & $35(15.8)$ & 0 & $11(14.5)$ & $24(18.2)$ & \\
\hline & Unknown (n, \%) & $3(1.4)$ & 0 & $1(1.3)$ & $2(1.5)$ & \\
\hline \multirow[t]{2}{*}{ Maximum tumour size } & $\begin{array}{l}\text { mm } \\
\text { (median, range) }\end{array}$ & $10[2-50]$ & $10[5-30]$ & $10[3-30]$ & $8[2-50]$ & \multirow[t]{2}{*}{$0.06^{* \prime}$} \\
\hline & Unknown (n, \%) & $42(19)$ & $2(15.4)$ & $16(21.1)$ & $24(18.2)$ & \\
\hline
\end{tabular}

* group differences were tested with chi square test

** group differences were tested with the Kruskal-Wallis 


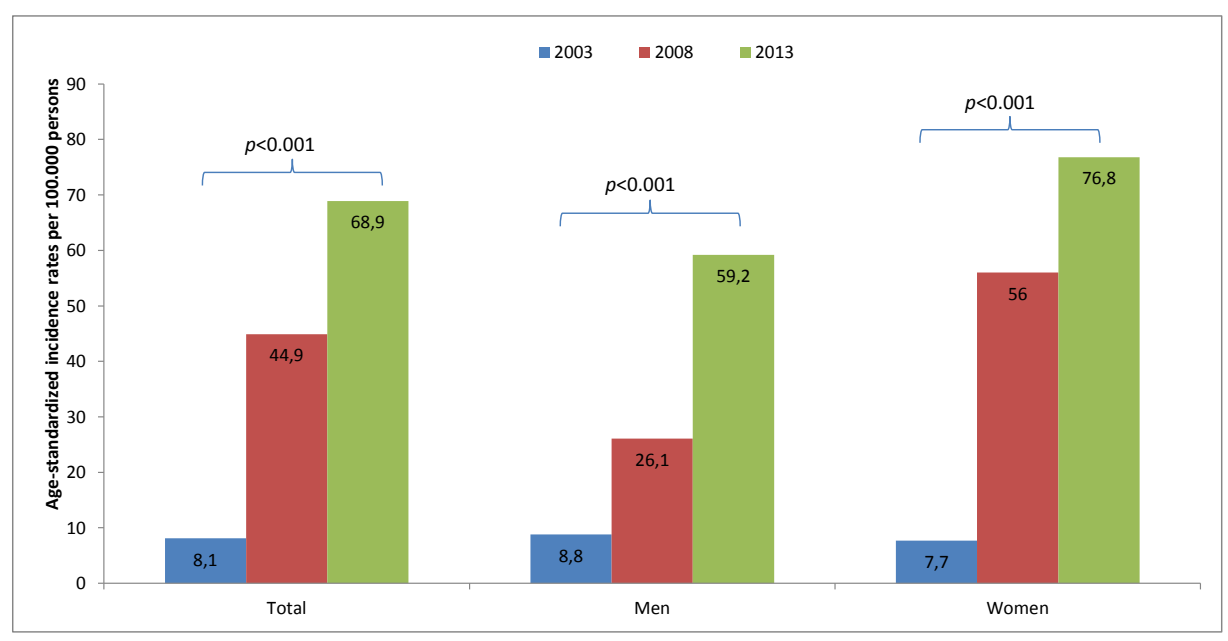

Figure 2. Age-standardized incidence rates per 100,000 persons in of Bowen's disease for the years 2003 , 2008 and 2013 in the district of Maastricht.

\section{DISCUSSION}

This retrospective study reports age-standardized incidence rates for histologically verified Bowen's disease and trends in incidence in Maastricht, the Netherlands. The results showed a statistically significant trend with a substantial increase of histologically confirmed BD between 2003 and 2013.

There are several possible explanations for the increasing trend found in our study. As seen in other skin malignancies, the observed trend may reflect an actual increase in incidence of BD. Sun exposure is an important risk factor for BD as it is for other non-melanoma skin cancer. ${ }^{11-13}$ The increase of affordable sun exposure may result in higher incidence of BD, which is supported by the higher proportion of patients with BD located on areas exposed to the sun during leisure time (trunk) (Table 1). Both the increased incidence and the shift to preferential localization on the trunk have been observed in other sun-related skin neoplasms (e.g. superficial BCC). ${ }^{14}$

The observed trend may also be the result of more frequent histological examination of clinically suspected skin lesions. Furthermore, a rising awareness can be an explanation for the increased number of biopsies taken by physicians. A PALGA search for lesions in the spectrum of BD for 2003, 2008 and 2013 also showed an increasing trend in the number of AK and SCC. 
There is limited literature on the incidence rates and trends in BD. Previous studies on the incidence of BD were performed in different countries and in different periods, and the incidence rates varied a lot. ${ }^{5-7}$ The study of Reizner et al. is the only study that reports on the incidence trend in BD. Fluctuations were found, but no trend was observed in this five-year study period. ${ }^{6}$ Notably, this study was performed in a different population in a sunny climate. Similar to our findings, an increase in the incidence of SCC since 1989 was found in a different study performed in the Netherlands, with an accelerated increase in incidence rates of SCC in females and males since 2002 and 2003, respectively. ${ }^{15}$ Furthermore, a previous study that addressed the incidence rates of BCC in the same region as ours between 1991 and 2007 in a comparable population as our population found an increase in the incidence of BCC, especially sBCC. ${ }^{14}$

$\mathrm{BD}$ is not registered in the Dutch cancer registries. Therefore, these data had to be derived from a hospital-based registry. A limitation is that our data was derived from one hospital, the MUMC+. This is a referral centre for dermatological oncology and therefore the tumours of BD diagnosed could represent a selected sample. To reduce selection bias, we only included the patients who live in the adherence area of the MUMC+. It seems reasonable to assume that the observed changes in the MUMC+ adherence region represent a realistic trend.

In conclusion, the results of this study based on histologically verified diagnoses of BD indicate an increase in the annual age-standardized incidence rates of BD in the Netherlands.

\section{ACKNOWLEDGEMENTS}

We are especially thankful for the effort of dr. N. Kelleners-Smeets to our study. 


\section{REFERENCES}

1. Lomas A, Leonardi-Bee J, Bath-Hextall F. A systematic review of worldwide incidence of nonmelanoma skin cancer. The British journal of dermatology. 2012;166(5):1069-1080.

2. Bowen JT. Centennial paper. May 1912 (J Cutan Dis Syph 1912;30:241-255). Precancerous dermatoses: a study of two cases of chronic atypical epithelial proliferation. By John T. Bowen, M.D., Boston. Arch Dermatol. 1983;119(3):243-260.

3. Peterka ES, Lynch FW, Goltz RW. An association between Bowen's disease and internal cancer. Arch Dermatol. 1961;84:623-629.

4. Kao GF. Carcinoma arising in Bowen's disease. Arch Dermatol. 1986;122(10):1124-1126.

5. Chute CG, Chuang TY, Bergstralh EJ, Su WP. The subsequent risk of internal cancer with Bowen's disease. A population-based study. Jama. 1991;266(6):816-819.

6. Reizner GT, Chuang T-Y, Elpern DJ, Stone JL, Farmer ER. Bowen's disease (squamous cell carcinoma in situ) in Kauai, Hawaii. Journal of the American Academy of Dermatology. 1994;31(4):596-600.

7. Arlette JP, Trotter MJ. Squamous cell carcinoma in situ of the skin: history, presentation, biology and treatment. Australas J Dermatol. 2004;45(1):1-9; quiz 10.

8. Bonerandi $\mathrm{J}$, Beauvillain C, Caquant L, et al. Guidelines for the diagnosis and treatment of cutaneous squamous cell carcinoma and precursor lesions. Journal of the European Academy of Dermatology and Venereology : JEADV. 2011;25 Suppl 5:1-51.

9. Pace M, Lanzieri G, Glickman G, et al. Revision of the European Standard Population. Report of Eurostat's task force. In: papers. EMaW, ed. . Luxembourg: Publications Office of the European Union; 2013: http://ec.europa.eu/eurostat/documents/3859598/5926869/KS-RA-13-028-EN.PDF/ e713fa79-1add-44e8-b23d-5e8fa09b3f8f.

10. Martin G, Swanson N. Clinical findings using ingenol mebutate gel to treat actinic keratoses. Journal of the American Academy of Dermatology. 2013;68(1 Suppl 1):S39-48.

11. Bath-Hextall FJ, Matin RN, Wilkinson D, Leonardi-Bee J. Interventions for cutaneous Bowen's disease. The Cochrane database of systematic reviews. 2013;6:Cd007281.

12. Verkouteren JA, Ramdas KH, Wakkee M, Nijsten T. Epidemiology of basal cell carcinoma: scholarly review. The British journal of dermatology. 2017;177(2):359-372.

13. Schmitt J, Seidler A, Diepgen TL, Bauer A. Occupational ultraviolet light exposure increases the risk for the development of cutaneous squamous cell carcinoma: a systematic review and meta-analysis. The British journal of dermatology. 2011;164(2):291-307.

14. Arits AH, Schlangen MH, Nelemans PJ, Kelleners-Smeets NW. Trends in the incidence of basal cell carcinoma by histopathological subtype. Journal of the European Academy of Dermatology and Venereology: JEADV. 2011;25(5):565-569.

15. Hollestein LM, de Vries E, Nijsten T. Trends of cutaneous squamous cell carcinoma in the Netherlands: increased incidence rates, but stable relative survival and mortality 1989-2008. European journal of cancer (Oxford, England: 1990). 2012;48(13):2046-2053. 





\section{INTRODUCTION}

Bowen's disease (BD) is an intra-epidermally located squamous cell carcinoma (SCC) in situ, which occurs mostly on sun-exposed areas. ${ }^{1-4}$ Several treatment modalities are described, including surgical excision (SE), imiquimod, 5-fluorouracil (5-FU), photodynamic therapy (PDT), curettage, and cryotherapy. ${ }^{4-8}$ The major advantage of SE is histological evaluation. However, SE comes with complications and scarring. Topical therapies are less invasive, often have cosmetic superiority, enable treatment of multiple tumours at once and might be preferable for tumours in locations where excision may be complicated by delayed wound healing.

We analysed the clinical effectiveness of 5-FU and PDT, compared with SE in a large study population at our department.

\section{MATERIALS AND METHODS}

Patients were retrospectively selected from the histological database from the Pathology Department of the Maastricht University Medical Centre (MUMC+), the Netherlands. Patients eligible for inclusion were those diagnosed with a histologically confirmed BD between 1 January 2008 and 31 December 2013 and treated by dermatologists. Exclusion criteria were: patients with BD on genitalia/mucous membranes or lesions found nearby an invasive skin cancer. Patient, tumour, and treatment characteristics were reviewed from medical records. The study was approved by the local Medical Ethics Committee.

Tumours were excised with a $5 \mathrm{~mm}$ safety margin, followed by routine histological examination. For PDT, application of aminolevulinic acid (ALA) or methylaminolevulinate (MAL) cream was followed by illumination (Aktilite ${ }^{\circledR}, 630 \mathrm{~nm}$, Galderma, SA, Lausanne, Switzerland) and repeated after one week. ${ }^{4,9}$ For 5-FU, patients applied 5-FU 5\% cream twice daily for 4 weeks. ${ }^{4}$

Treatment failure was defined as clinical evidence of residual tumour, tumour recurrence or progression into an invasive tumour. Tumour presence or keratosis at the site of the initial tumour on first (3 months) follow-up visit following 5-FU or PDT, was considered residual tumour. For SE, information on residual lesions was obtained from the pathology report. Recurrence was defined as a new proliferation at the site of the original tumour. When doubtful, the suspicion was histopathologically confirmed. 


\section{Statistical analyses}

Descriptive results are presented as numbers and percentages for categorical variables and as means ( \pm standard deviation) for continuous variables. The Chi-square test and one-way analysis of variance (ANOVA) were used to test differences between treatment groups for statistical significance. Cumulative probability of treatment failure at 1, 2 and 5-years followup was calculated with Kaplan-Meier analysis and the log-rank test was used for comparison between treatments. Follow-up ended at the date of diagnosis of treatment failure or at the date of last follow-up visit. Cox regression analysis was performed to calculate hazard ratios (HR) with 95\% confidence intervals (95\% Cl) using SE as the reference group. Variables coding for relevant baseline characteristics (age, sex, lesion diameter, tumour localization and use of immunosuppressive medication) were entered as independent variables to adjust for potential confounding due to differences in baseline characteristics between treatment groups. Missing values on tumour diameter were dealt with by using multiple imputation techniques. P-values $\leq 0.05$ were considered to indicate statistical significance. Data analyses were performed with SPSS 23.0 (IBM Corp., Armonk, NY, USA) and Stata Version 14 (Stata Corp, College Station, TX).

\section{RESULTS}

A total of 1,688 histological reports on BD were identified. Of those, 847 cases were excluded (Figure 1). A total of 841 tumours in 608 patients were included. Baseline characteristics are shown in Table 1. Most patients were treated with either SE $(n=296)$ or PDT ( $n=241)$. 5-FU was used in 46 patients. The majority of patients (78.6\%) had only one BD. Median follow-up was 18 months (range 0-87 months).

Cumulative probabilities of treatment failure are summarized in Table 2. The number of recurrences following 5-FU remained more or less stable after one year, whereas recurrences post-PDT developed even after 3 years. Crude and adjusted hazard ratios (HRs) for PDT and 5-FU compared to SE are summarized in Table 3. After adjustment for differences in baseline characteristics between the treatment groups, PDT is associated with a significantly higher risk of treatment failure than SE ( $\mathrm{HR}=2.71$ with 95\% $\mathrm{Cl}$ : 1.52-4.83). 5-FU also showed increased risk compared to SE (adjusted HR=2.22, 95\% Cl: 0.98-5.04). A slightly higher, statistically nonsignificant, risk was found for PDT compared with 5-FU (adjusted HR=1.22, 95\% Cl: 0.62-2.41).

Of all treated BD ( $n=841), 8$ tumours ( $<1 \%)$ progressed into an invasive SCC 3-42 months post-treatment. Seven SCCs (2.4\%) occurred in patients post-PDT and one (2.1\%) after 5-FU. 


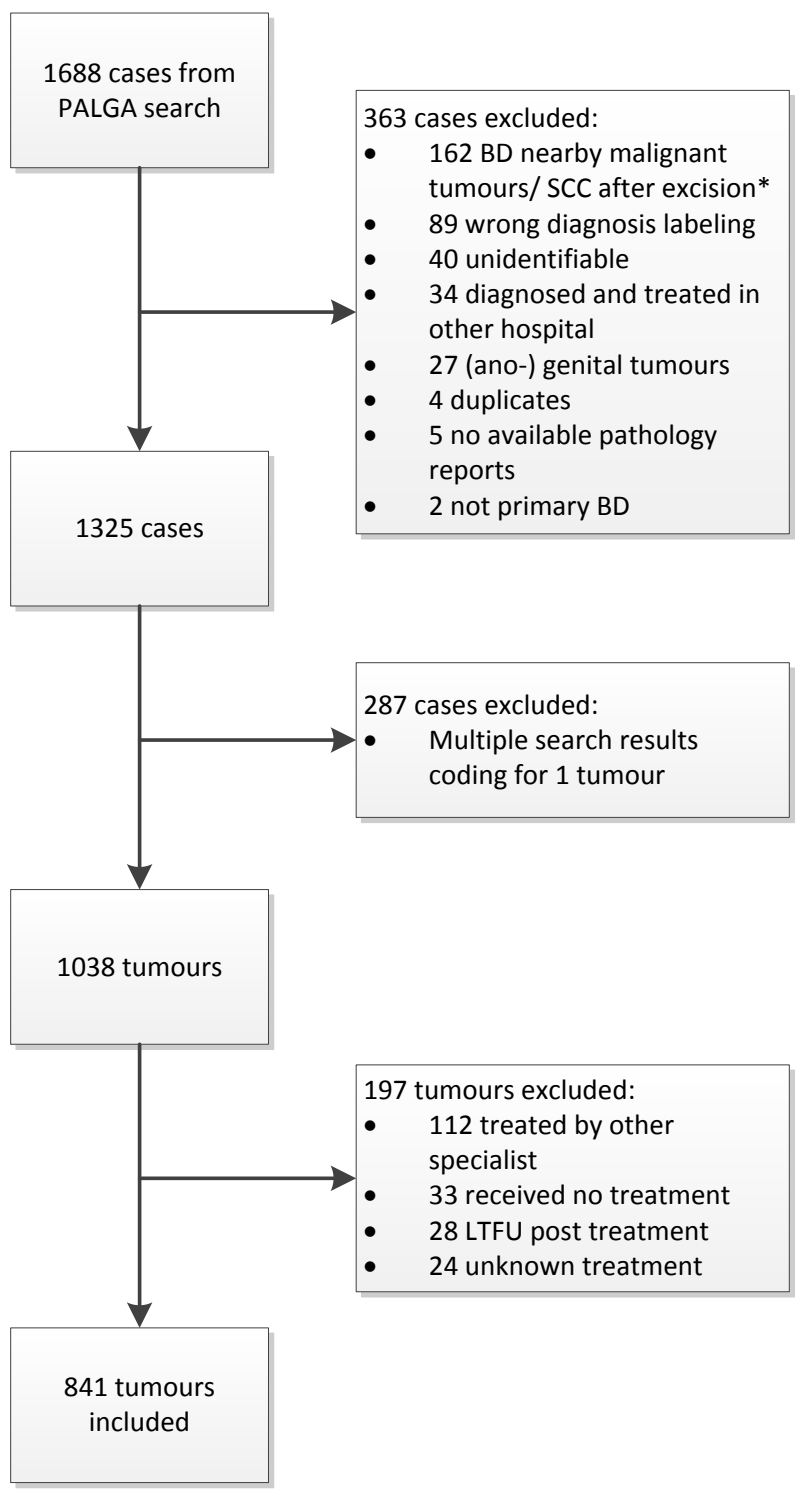

BD, Bowen's Disease; SCC, squamous cell carcinoma; LTFU, lost to follow-up immediately post treatment; MUMC, Maastricht University Medical Centre;

* In 107 cases (66\%) the histopathological diagnosis on biopsy was an invasive tumour (e.g. SCC, BCC) but the excision showed BD next to the invasive tumour; in 18 cases (11\%) the biopsy showed $\mathrm{BD}$, but the excision specimen contained an invasive tumour; in 37 cases (23\%) the initial histopathological diagnosis on biopsy could not exclude invasive malignancy but the excision specimen showed an invasive tumour.

Figure 1. Flow chart. 


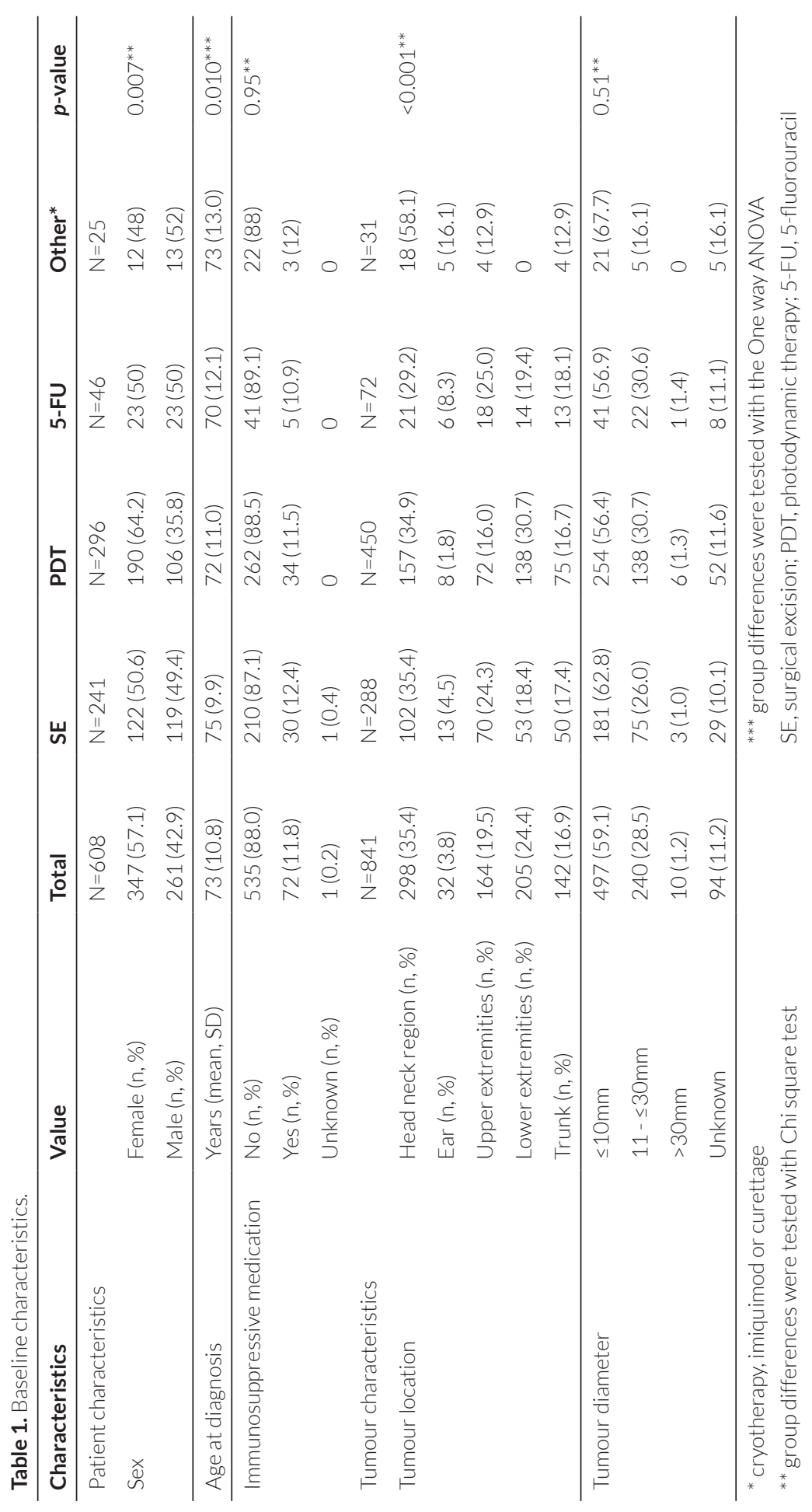


Table 2. Cumulative probability of treatment failure after SE versus PDT versus 5-FU, based on Kaplan-Meier survival analysis.

\begin{tabular}{|c|c|c|c|c|}
\hline \multirow[b]{2}{*}{ Follow-up, months } & \multicolumn{4}{|c|}{ Cumulative treatment failure probability $\left(95 \% \mathrm{Cl}^{\mathrm{b}}\right)$} \\
\hline & SE & PDT & $5-\mathrm{FU}$ & $p$-value \\
\hline 3 & $4.9 \%(2.9-8.1)$ & $2.7 \%(1.5-4.7)$ & $5.9 \%(2.3-15.0)$ & \\
\hline 6 & $4.9 \%(2.9-8.1)$ & $9.1 \%(6.7-12.2)$ & $7.5 \%(3.2-17.1)$ & \\
\hline 12 & $4.9 \%(2.9-8.1)$ & $13.4 \%(10.4-17.1)$ & $13.1 \%(6.7-24.7)$ & \\
\hline 24 & $4.9 \%(2.9-8.1)$ & $17.0 \%(13.5-21.3)$ & $15.5 \%(8.3-27.9)$ & \\
\hline 36 & $4.9 \%(2.9-8.1)$ & $19.2 \%(15.4-23.7)$ & $15.5 \%(8.3-27.9)$ & \\
\hline 48 & $4.9 \%(2.9-8.1)$ & $22.3 \%(17.9-27.6)$ & $15.5 \%(8.3-27.9)$ & \\
\hline 60 & $4.9 \%(2.9-8.1)$ & $22.3 \%(17.9-27.6)$ & $15.5 \%(8.3-27.9)$ & $0.001^{a}$ \\
\hline
\end{tabular}

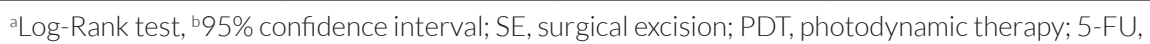

5-fluorouracil

Table 3. Hazard ratios with $95 \%$ confidence intervals $(95 \% \mathrm{CI})$ for treatment failure with and without adjustment for potential confounders.

\begin{tabular}{|c|c|c|c|c|c|c|}
\hline \multirow[b]{2}{*}{ Determinant } & \multicolumn{3}{|c|}{ Univariate analysis } & \multicolumn{3}{|c|}{ Multivariate analysis } \\
\hline & Unadjusted HR & $95 \% \mathrm{Cl}$ & $p$-value & Adjusted HR & $95 \% \mathrm{Cl}$ & $p$-value \\
\hline \multicolumn{7}{|l|}{ Treatment received } \\
\hline SE & 1 (reference) & - & - & 1 (reference) & - & - \\
\hline PDT & 2.78 & $1.57-4.91$ & $<0.001$ & 2.71 & $1.52-4.83$ & 0.001 \\
\hline 5-FU & 2.50 & $1.11-5.62$ & 0.03 & 2.22 & $0.98-5.04$ & 0.06 \\
\hline Age & 1.00 & 0.98-1.02 & 0.69 & 1.01 & $0.99-1.03$ & 0.55 \\
\hline Sex (M to F) & & & & 1.00 & 0.65-1.56 & 0.99 \\
\hline \multicolumn{7}{|l|}{ Lesion diameter } \\
\hline$\leq 10 \mathrm{~mm}$ & & & & 1 (reference) & - & - \\
\hline $11-\leq 30 \mathrm{~mm}$ & & & & 1.35 & $0.86-2.12$ & 0.20 \\
\hline$>30 \mathrm{~mm}$ & & & & 3.24 & $0.98-10.65$ & 0.05 \\
\hline \multicolumn{7}{|l|}{ Localization } \\
\hline Head/Neck & & & & 1 (reference) & & - \\
\hline Ear & & & & 2.34 & $0.83-6.18$ & 0.08 \\
\hline Trunk & & & & 0.74 & $0.40-1.38$ & 0.34 \\
\hline Upper extremity & & & & 0.81 & $0.45-1.48$ & 0.50 \\
\hline Lower extremity & & & & 0.92 & $0.55-1.54$ & 0.75 \\
\hline $\begin{array}{l}\text { Immunosuppression } \\
\text { (present to absent) }\end{array}$ & & & & 1.92 & $1.18-3.11$ & 0.01 \\
\hline
\end{tabular}

*Hazard ratios (HR) > 1 indicate increased risk of treatment failure. SE, surgical excision; PDT, photodynamic therapy; 5-FU, 5-fluorouracil 


\section{DISCUSSION}

The results of this study show that BD treated with 5-FU and PDT have a more than 2-fold increased 5-year probability of treatment failure compared with SE, whereas there is no statistically significant difference between 5-FU and PDT. Only a small percentage of the tumours treated with non-invasive therapy progressed into an invasive SCC.

A systematic review assessed the different therapies of BD, including 9 studies: PDT and 5-FU appeared effective, but due to limited evidence no firm conclusions on comparative effectiveness were made.? SE was not included, because of an absence of comparative studies. Morton et al. showed estimated complete response rates of $80 \%$ for MAL-PDT ( $n=96$ ) and 69\% for 5-FU ( $n=30$ ) after 12 months follow-up. ${ }^{10}$ Salim et al. demonstrated a significantly better effectiveness of ALA-PDT (82\%) compared with 5-FU (48\%) in 66 BD in 40 patients. ${ }^{11}$ SE showed the lowest recurrence rates of $0.8-5.5 \%$. 3,12

In our study population, 8 tumours progressed into a SCC after non-invasive therapies. SCCS following complete excision were not observed, but we did find 18 SCC in the excision specimen that were diagnosed as BD on a biopsy. These cases were excluded from further analysis. This finding may indicate that BD lesions treated with SE represent a group with higher clinical suspicion of SCC, which treating physicians consider as unsuitable for treatment with noninvasive modalities. Invasive progression of $2.3-12.6 \%$ is reported in the literature after treatment with excision, cryotherapy or PDT. ${ }^{12,13}$

We found differences in onset of treatment failure occurrence, with especially PDT-treated tumours developing recurrences still after three years. Late recurrences have also been observed following treatment of sBCC and this underlines the need for long-term follow-up after treatment with non-invasive therapies. ${ }^{14}$

Although SE is associated with a lower probability of treatment failure, non-invasive therapies can be considered as an option for tumours at sites with poor/delayed wound-healing and in case of large/multiple tumours. ${ }^{4-6}$ Differences in cosmetic results, patient preferences and costs should be taken into account when choosing a therapy. Patients should be informed about all aspects in order to make a conscious shared decision.

Because of the non-randomized design, bias due to confounding by indication cannot be ruled out. We attempted to minimize this bias by adjustment for differences in baseline characteristics, but it is possible that not all relevant determinants were captured in the multivariable Cox regression model. Because of the retrospective nature, information on the used photosensitizer could not be retrieved; therefore separate analyses for ALA- vs. MAL-PDT were not possible. 
In conclusion, this study showed that SE is associated with the lowest probability of treatment failure in the management of BD. No significant difference between 5-FU and PDT was found, up to 5-years post-treatment. 


\section{REFERENCES}

1. Bowen JT. Centennial paper. May 1912 (J Cutan Dis Syph 1912;30:241-255). Precancerous dermatoses: a study of two cases of chronic atypical epithelial proliferation. By John T. Bowen, M.D., Boston. Arch Dermatol 1983;119:243-60.

2. Arlette JP, Trotter MJ. Squamous cell carcinoma in situ of the skin: history, presentation, biology and treatment. Australas J Dermatol 2004;45:1-9; quiz 10.

3. Hansen JP, Drake AL, Walling HW. Bowen's Disease: a four-year retrospective review of epidemiology and treatment at a university center. Dermatologic surgery: official publication for American Society for Dermatologic Surgery [et al] 2008;34:878-83.

4. Morton CA, Birnie AJ, Eedy DJ. British Association of Dermatologists' guidelines for the management of squamous cell carcinoma in situ (Bowen's disease) 2014. The British journal of dermatology 2014;170:245-60.

5. Bonerandi J J, Beauvillain C, Caquant L, et al. Guidelines for the diagnosis and treatment of cutaneous squamous cell carcinoma and precursor lesions. Journal of the European Academy of Dermatology and Venereology: JEADV 2011;25 Suppl 5:1-51.

6. Szeimies RM, Karrer S, Backer H. [Therapeutic options for epithelial skin tumors. Actinic keratoses, Bowen disease, squamous cell carcinoma, and basal cell carcinoma]. Der Hautarzt; Zeitschrift fur Dermatologie, Venerologie, und verwandte Gebiete 2005;56:430-40.

7. Bath-Hextall FJ, Matin RN, Wilkinson D, Leonardi-Bee J. Interventions for cutaneous Bowen's disease. The Cochrane database of systematic reviews 2013;6:Cd007281.

8. Clinical practice guidelines in oncology. Basal cell and squamous cell skin cancers. 2012. at http://www. nccn.org/professionals.)

9. Morton CA, Szeimies RM, Sidoroff A, Braathen LR. European guidelines for topical photodynamic therapy part 1: treatment delivery and current indications - actinic keratoses, Bowen's disease, basal cell carcinoma. Journal of the European Academy of Dermatology and Venereology: JEADV 2013;27:53644.

10. Morton C, Horn M, Leman J, et al. Comparison of topical methyl aminolevulinate photodynamic therapy with cryotherapy or Fluorouracil for treatment of squamous cell carcinoma in situ: Results of a multicenter randomized trial. Arch Dermatol 2006;142:729-35.

11. Salim A, Leman JA, McColl JH, Chapman R, Morton CA. Randomized comparison of photodynamic therapy with topical 5-fluorouracil in Bowen's disease. The British journal of dermatology 2003;148:53943.

12. Overmark M, Koskenmies S, Pitkanen S. A Retrospective Study of Treatment of Squamous Cell Carcinoma In situ. Acta dermato-venereologica 2016;96:64-7.

13. Ratour-Bigot C, Chemidling M, Montlahuc C, et al. Squamous Cell Carcinoma Following Photodynamic Therapy for Cutaneous Bowen's Disease in a Series of 105 Patients. Acta dermato-venereologica 2016;96:658-63.

14. Roozeboom MH, Arits AH, Mosterd K, et al. Three-Year Follow-Up Results of Photodynamic Therapy vs. Imiquimod vs. Fluorouracil for Treatment of Superficial Basal Cell Carcinoma: A Single-Blind, Noninferiority, Randomized Controlled Trial. The Journal of investigative dermatology 2016;136:156874. 



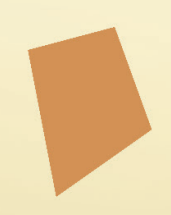

\section{CHAPHER4}

\section{Long-term follow-up results in the treatment of superficial basal cell carcinoma}




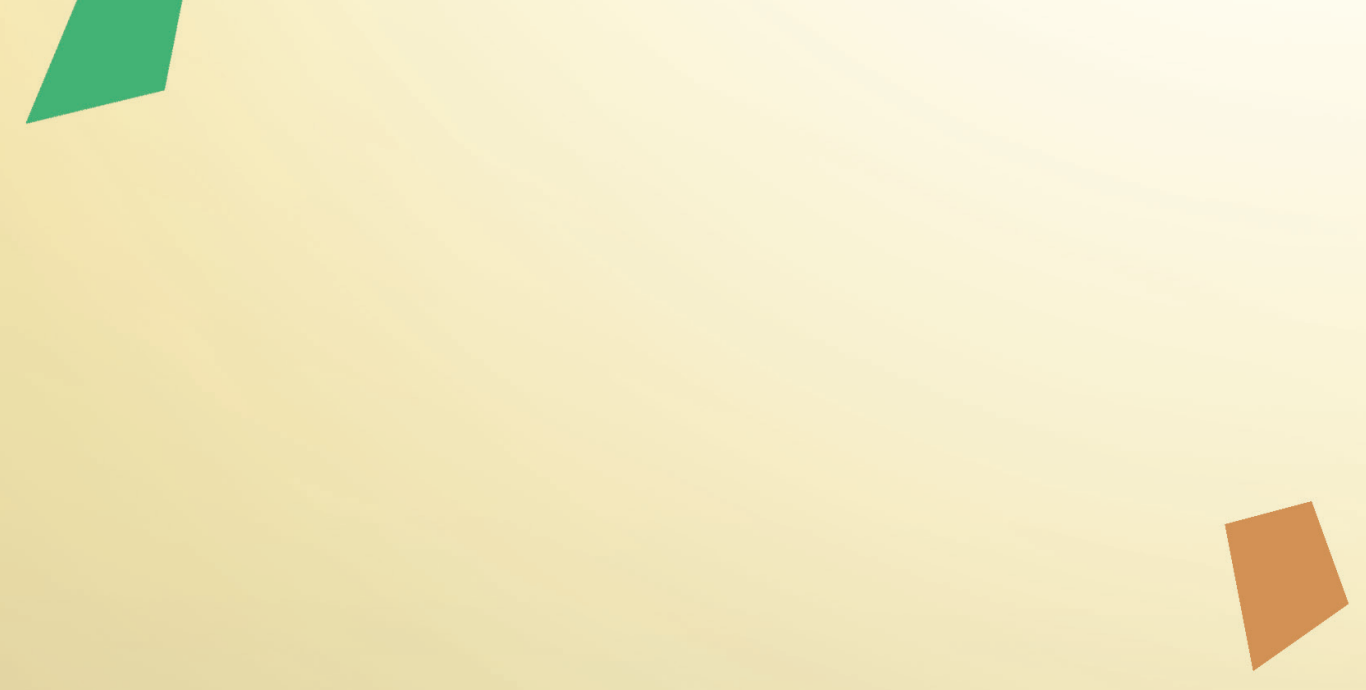

\section{CHAPTER 4.1}

\section{Five-year results of a randomized controlled trial comparing effectiveness of photodynamic therapy, topical imiquimod and 5-fluorouracil in patients with superficial basal cell carcinoma}

M.H.E. Jansen, K. Mosterd, A.H.M.M. Arits, M.H. Roozeboom, A. Sommer, B.A.B. Essers, J.P.A. van Pelt, P.J.F. Quaedvlieg, P.M. Steijlen, P.J. Nelemans, N.W.J. Kelleners-Smeets 


\section{ABSTRACT}

For the treatment of superficial basal cell carcinoma, a prospective non-inferiority randomized controlled multicentre trial with 601 patients showed that 5\% imiquimod cream was superior and 5-fluorouracil cream not inferior to methylaminolevulinate photodynamic therapy (MALPDT) at one and three year post-treatment. No definite conclusion could be drawn regarding the superiority of imiquimod over 5 -fluorouracil. We now present the five-year follow-up results according to the intention-to-treat analysis.

Five years post-treatment the probability of tumour-free survival was $62.7 \%$ for MAL-PDT (95\% confidence interval (CI) 55.3-69.2), 80.5\% for imiquimod (95\% Cl 74.0-85.6), and 70.0\% for 5-fluorouracil (95\% Cl 62.9-76.0). The hazard ratio (HR) for treatment failure of imiquimod and 5-fluorouracil were $0.48(95 \% \mathrm{Cl} 0.32-0.71, p<0.001)$ and $0.74(95 \% \mathrm{Cl} 0.53-1.05, p=0.09)$, respectively, when compared to MAL-PDT. Compared to 5-fluorouracil, imiquimod showed a HR of 0.65 (95\% Cl 0.43-0.98, $p=0.04)$.

In conclusion, five years post-treatment, the results of this trial show that $5 \%$ imiquimod cream is superior to both MAL-PDT and 5-fluorouracil cream in terms of effectiveness for superficial basal cell carcinoma. We therefore consider $5 \%$ imiquimod cream as the first choice non-invasive treatment in most primary superficial basal cell carcinomas. 


\section{INTRODUCTION}

Basal cell carcinoma (BCC), the most common non melanoma skin cancer among Caucasian, is an important health problem worldwide with a rapidly increasing incidence. ${ }^{1,2} \mathrm{As}$ a result, $\mathrm{BCC}$ causes high medical consumption and health care costs. ${ }^{3}$

Although surgical excision is the gold standard for treatment of BCCs, different studies suggest that non-invasive therapies are useful alternatives to surgery in treatment of superficial BCC (sBCC). 4.5 Besides being less invasive, topical therapies also have other advantages like the good cosmetic outcome according to evaluation by physicians. ${ }^{5-7}$

Only a few studies on long-term effectiveness of non-invasive treatment of sBCC have been published. Head-to-head studies are pivotal to reach consensus in international BCC guidelines on the first choice non-invasive treatment to compare effectiveness. ${ }^{4,8}$ We previously showed that the effectiveness of $5 \%$ imiquimod cream is superior and 5 -fluorouracil cream not inferior to methylaminolevulinate photodynamic therapy (MAL-PDT) in the treatment of sBCC at three years follow-up. ${ }^{9}$ Both creams were also found to be cost-effective compared to MAL-PDT one year post-treatment. ${ }^{10}$ The aim of this study is to report the comparative effectiveness of MALPDT, imiquimod and 5-fluorouracil five years post-treatment.

\section{MATERIAL AND METHODS}

\section{Protocol}

Long-term results were evaluated with data from a single-blinded, non-inferiority, multicentre study in which patients with sBCC were randomized between treatment with MAL-PDT, imiquimod or 5-fluorouracil cream. ${ }^{11}$ Patients were recruited at the departments of Dermatology in seven hospitals in the Netherlands between March 2008 and August 2010. The extensive study design and procedures have been described elsewhere, but will be briefly described here.9,11

Primary inclusion criteria for the 601 participants were patients with a primary sBCC that was histologically confirmed on a $3 \mathrm{~mm}$ punch skin biopsy. One tumour per patient was included. Excluded were patients using immunosuppressive drugs, suffering from genetic cutaneous cancer disorders, having tumours located in the high-risk area of the face $(\mathrm{H}$-zone) or scalp, and women who were pregnant or breastfeeding.

Treatment with MAL-PDT (Metvix®, Galderma SA, Penn Pharmaceutical Services, Gwent, UK) involved two single treatments with one week interval (fluency $630 \mathrm{~nm}$, dose $37 \mathrm{~J} / \mathrm{cm}^{2}$ ). Patients randomized to $5 \%$ imiquimod cream (Aldara $\AA$, Meda AB, Solna, Sweden) applied the cream 
once daily for 5 consecutive days a week, for 6 weeks. 5\% 5-fluorouracil cream (Efudix $®$, Meda Pharmaceuticals, Amstelveen, the Netherlands) involved application of the cream twice daily for 4 weeks.

The primary study outcome in this study was defined as the cumulative probability of remaining free of tumour recurrence at five years post-treatment, which is referred to as the 5-year probability of tumour-free survival. Treatment failure was defined as a histologically confirmed BCC on a skin biopsy of a clinically suspect area within 10-mm of the scar of the biopsy. Followup visits were planned at 3, 12, 36 and 60 months after end of treatment and were performed by an investigator who was blinded for treatment assignment.

The study was performed in accordance with the Declaration of Helsinki Principles and approval of the local medical ethics and scientific committee of the Maastricht University Medical Centre was obtained. All participants provided written, informed consent prior to enrolment. The trial was registered as International Standard Randomized Controlled Trial (ISRCTN 79701845).

\section{Assignment and masking}

Participants were randomly assigned to one of the three treatments in a 1:1:1 ratio. Stratifying factors were age and tumour location (head/neck vs. other). Follow-up visits were performed by an investigator who was blinded for treatment assignment and was not involved in the treatment. Patients and treating physicians were not blinded for the allocated treatment.

\section{Participant flow and follow-up}

All participating patients were invited for a follow-up visit at five years after the end of treatment. For logistical reasons, follow-up visits were planned within a window of six months prior or six months subsequent to the actual five year follow-up date.

\section{Statistical analysis}

Effectiveness

For descriptive purposes, categorical variables were presented as numbers and percentages and mean ( \pm standard deviation) or median with range were reported for continuous variables.

The original sample size of 197 patients per randomized group was based on the statistical ability to detect an absolute difference of $10 \%$ in 1-year probability of tumour-free survival (noninferiority margin) between groups, with a power of $80 \%$ and one-sided alpha of $5 \%$. The full rationale for the sample size calculation of this study has been described in earlier publications on this trial. ${ }^{9,11}$ 
Time-to-event analyses were performed to account for differences in follow-up between patients. In case of recurrence of a treated lesion, patients were censored at the date of recurrence or at the date of last follow-up visit. Due to logistic reasons the actual date of followup visits did not always coincide exactly with the planned dates (at 3, 12, 36 and 60 months after treatment). For the Kaplan Meier analysis we used the planned dates assuming that the observed health state (treatment failure or not) reflected the health state at the moment that the visit should have taken place.

Cox proportional hazards models were used to calculate hazard ratios (HRs) for treatment failure with 95\% confidence intervals (95\% CI). To facilitate interpretation of HRs, the noninferiority margin of $10 \%$ for absolute differences in tumour-free survival probability was translated into a non-inferiority threshold on the relative risk scale based on the observed five year tumour-free survival probability (p0) in the MAL-PDT group (log (p0-0.1)/log p0). ${ }^{12}$ Both intention-to-treat and per protocol analyses were performed.

All data were analysed using SPSS version 23.0 (IBM Corp., Armonk NY, USA) and STATA version 14.0 (STATA Corp, College Station, TX, U.S.A.).

\section{RESULTS}

\section{Patients}

A total of 601 patients with a primary histologically proven sBCC were randomly assigned to treatment with MAL-PDT ( $n=202)$, imiquimod ( $n=198)$, or 5-fluorouracil $(n=201)$. Baseline characteristics are presented in Table 1. Additional information on these characteristics can be found in a previous report. ${ }^{11}$ Patient flow from recruitment to the five-year follow-up visit is shown in Figure 1. All participating patients were invited for a follow-up visit at five years after the end of treatment. Five patients (2 MAL-PDT, 3 imiquimod), who were previously considered lost to follow-up because they were previously unable or unwilling to attend their follow-up visit, were willing to participate at the five-year follow-up visit. In five patients protocol deviations occurred because of strong clinical suspicion of recurrence: surgical excision in three patients and noninvasive treatment in two patients. Since these patients could not be assessed for recurrence to the primary non-invasive treatment during follow-up, they were considered lost to follow-up. A total of 87 patients (14.9\%) were lost to follow-up of whom 32 were treated with MAL-PDT, 31 with imiquimod and 24 with 5-fluorouracil. Reasons for not completing follow-up were: death due to causes unrelated to sBCC or treatment, refusal to attend follow-up visits, and other reasons such as inability of the patient to visit the hospital. The median follow-up period in the study was 64 months (range 1-93). 
Table 1. Distribution of patient and tumour characteristics.

\begin{tabular}{|c|c|c|c|}
\hline Characteristic & $\begin{array}{l}\text { MAL-PDT } \\
(n=202)\end{array}$ & $\begin{array}{l}\text { Imiquimod cream } \\
(\mathrm{n}=198)\end{array}$ & $\begin{array}{l}\text { 5-fluorouracil cream } \\
(\mathrm{n}=201)\end{array}$ \\
\hline \multicolumn{4}{|l|}{ Sex } \\
\hline Male & $96(48 \%)$ & $102(52 \%)$ & $106(53 \%)$ \\
\hline Female & $106(52 \%)$ & $96(48 \%)$ & $95(47 \%)$ \\
\hline $\begin{array}{l}\text { Median age in years } \\
\text { (range) }\end{array}$ & $63(26-87)$ & $62(30-91)$ & $64(35-86)$ \\
\hline $\begin{array}{l}\text { Median tumour size in } \\
\mathrm{mm}^{2} \text { (range) }\end{array}$ & $52(5-1382)$ & $63(5-1413)$ & $63(9-5472)$ \\
\hline \multicolumn{4}{|l|}{ Tumour location } \\
\hline Head/neck (reference) & $24(12 \%)$ & $23(12 \%)$ & 31 (15\%) \\
\hline Trunk & $119(59 \%)$ & $121(61 \%)$ & $120(60 \%)$ \\
\hline Upper extremities & $32(16 \%)$ & $26(13 \%)$ & $27(13 \%)$ \\
\hline Lower extremities & $27(13 \%)$ & $28(14 \%)$ & $23(11 \%)$ \\
\hline
\end{tabular}

Definition of abbreviations: MAL-PDT, methylaminolevulinate photodynamic therapy.

\section{Probability of tumour-free survival}

From randomization until five-years post-treatment; 70 tumour recurrences were found in the MAL-PDT group, 36 in the imiquimod group and 57 in the 5-fluorouracil group. Thirteen of the 70 recurrences occurred between three and five years of follow-up ( 4 after MAL-PDT, 2 after imiquimod, and 7 after 5-fluorouracil) (Figure 1 and 2).

Estimates of the cumulative probability of tumour-free survival, according to the intention-totreat and per protocol analysis, at one, three and five year post-treatment are presented in Table 2. At five years post-treatment the probability of tumour-free survival is $62.7 \%$ for MAL-PDT (95\% Cl 55.3-69.2), 80.5\% for imiquimod (95\% Cl 74.0-85.6), and 70.0\% for 5-fluorouracil (95\% $\mathrm{Cl}$ 62.9-76.0). Based on the estimated five-year tumour-free survival probability of $62.7 \%$ for MAL-PDT, the non-inferiority margin of $10 \%$ for absolute differences in survival probability translates to a non-inferiority threshold for the hazard ratio (HR) for treatment failure of 1.37 $(\log 0.527 / \log 0.627) .{ }^{12}$ Consequently, non-inferiority of both creams to MAL-PDT can be concluded if the $95 \% \mathrm{Cl}$ of the corresponding HRs are entirely below 1.37. Superiority of both creams to MAL-PDT can be concluded if the $95 \% \mathrm{Cl}$ of the corresponding HRs are entirely below 1.0. 


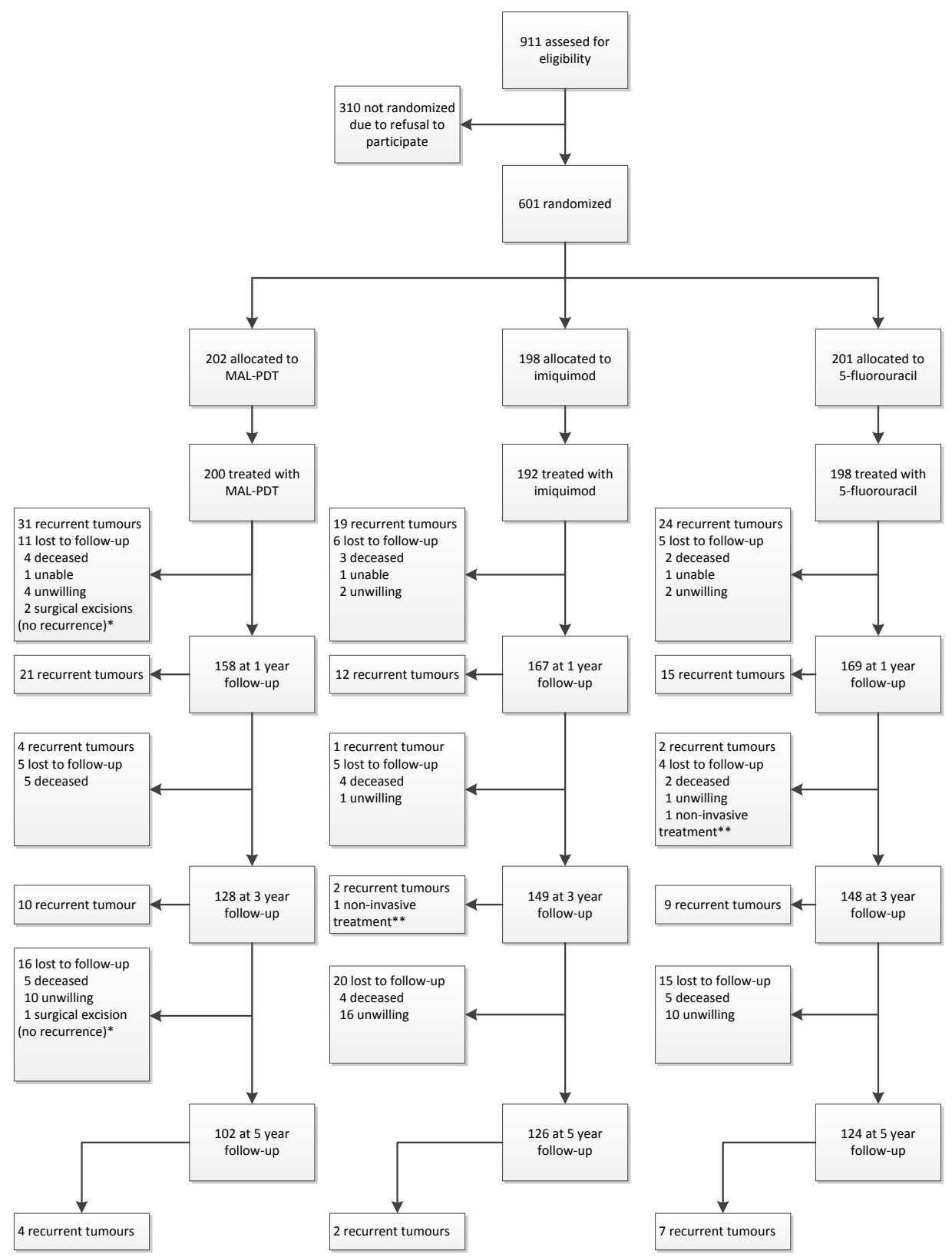

*Surgical excision was done in three patients due to a strong clinical suspicion of recurrence. Since these patients could not be assessed for recurrence during follow-up, they were considered lost to follow-up. ${ }^{* *}$ Non-invasive treatments were given in two patients due to a strong clinical suspicion of recurrence. Since these patients could not be assessed for recurrence to the primary non-invasive treatment during follow-up, they were considered lost to follow-up.

Figure 1. CONSORT flow chart, patient flow. 

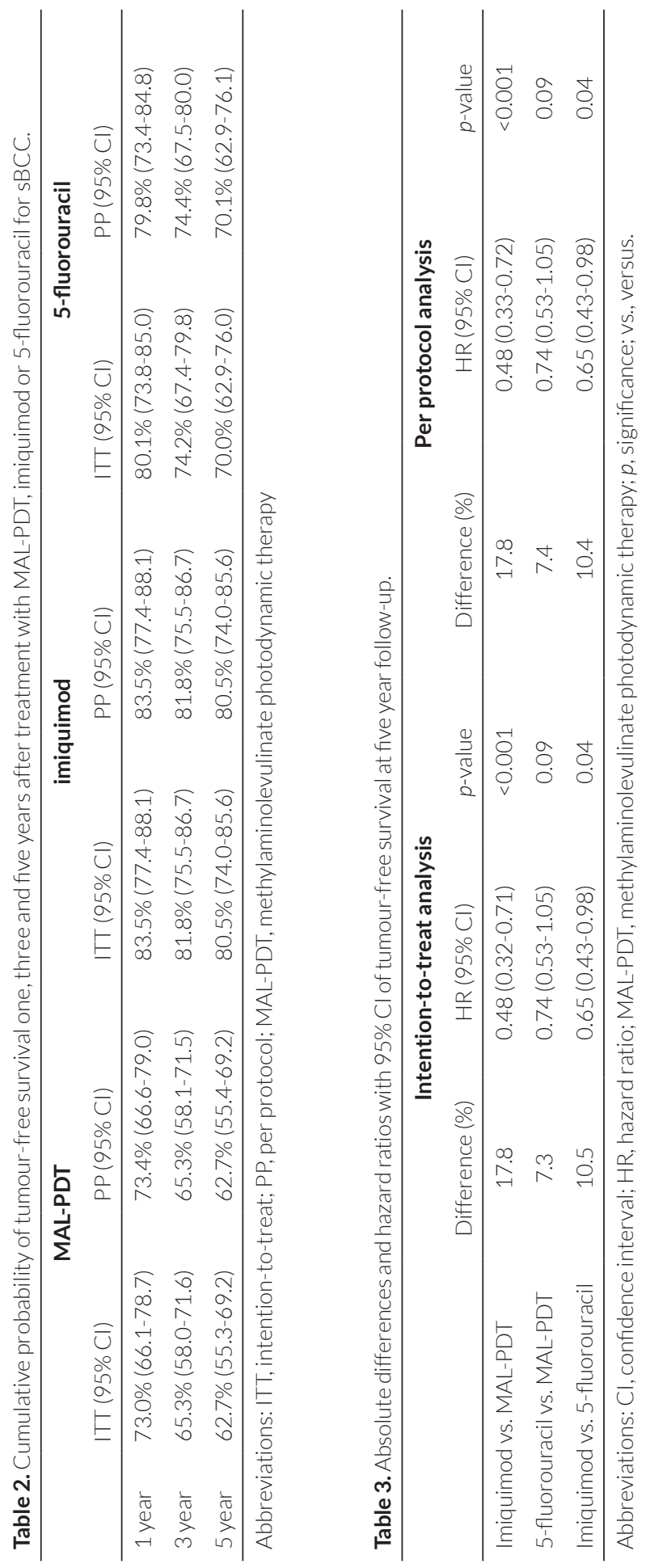


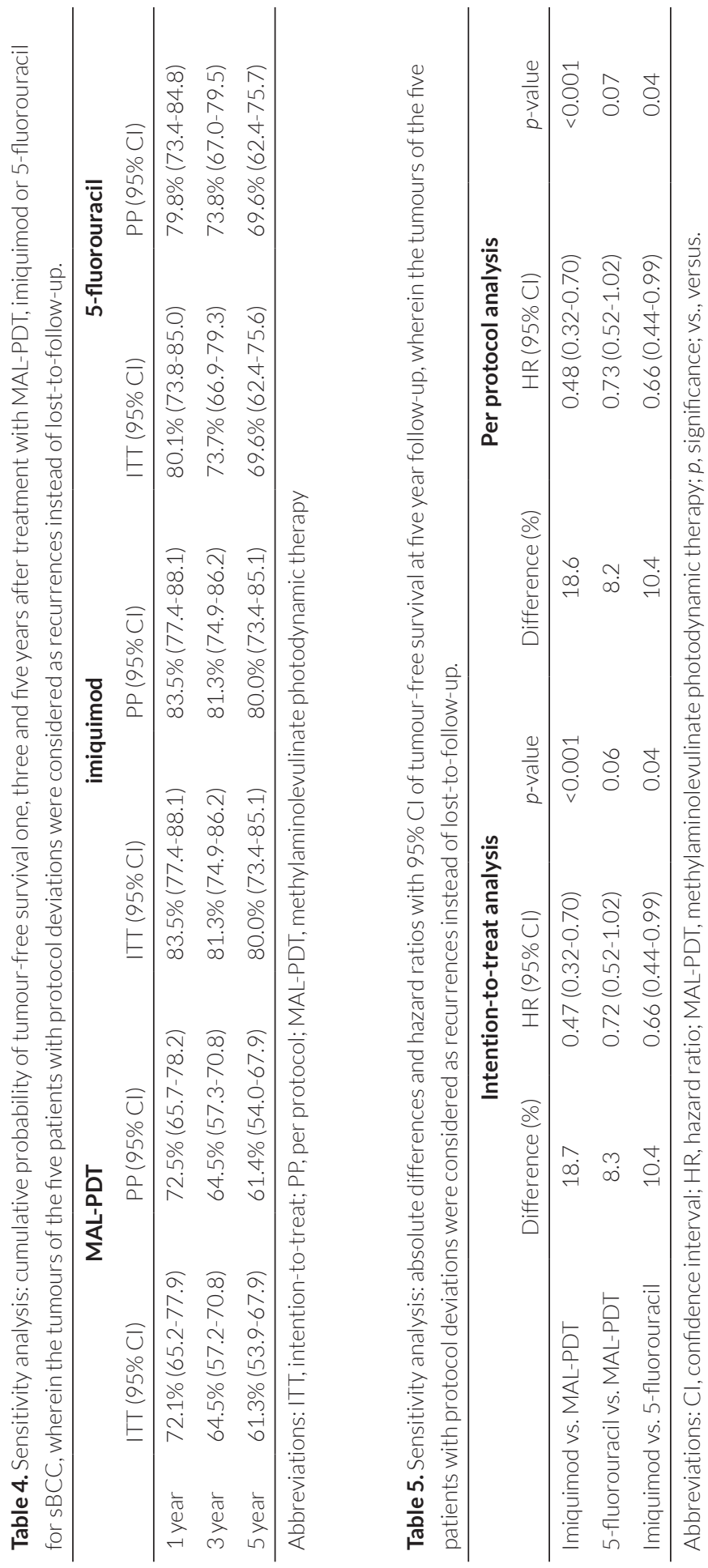

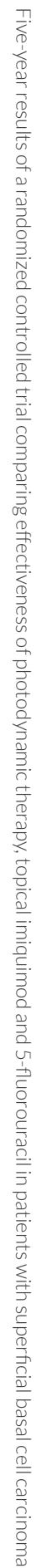




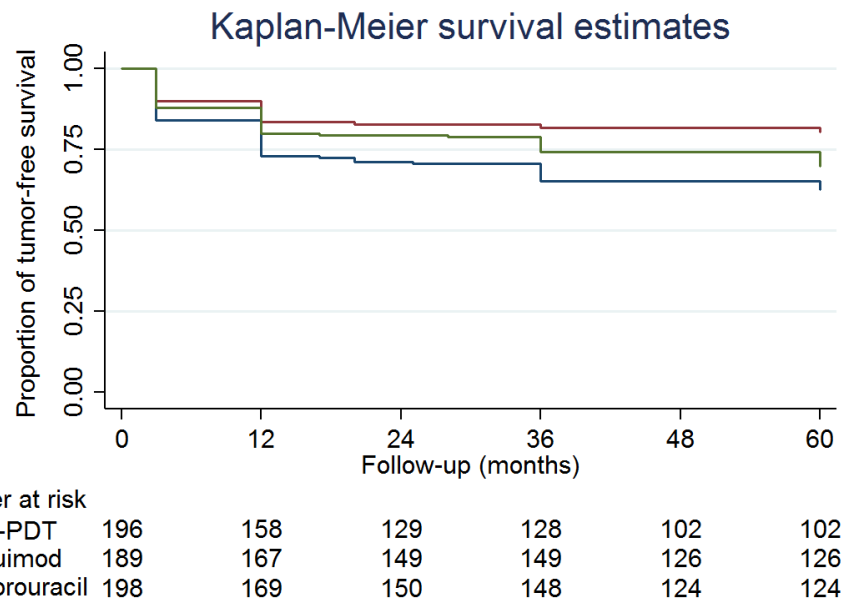

Figure 2. Kaplan-Meier Survival plot.

The HR for treatment failure comparing imiquimod with MAL-PDT was 0.48 (95\% Cl 0.32-0.71, $p<0.001$ ) (Table 3). The data also allow comparison of imiquimod with 5-fluorouracil. The HR of 0.65 (95\% Cl 0.43-0.98, $p=0.04$ ) shows that imiquimod is also superior to 5 -fluorouracil. Comparison of 5-fluorouracil with MAL-PDT resulted in a HR of $0.74(95 \% \mathrm{Cl}$ 0.53-1.05, $p=0.09$ ). According to the intention-to-treat analysis, after five years of follow-up, imiquimod was superior compared to MAL-PDT and 5-fluorouracil. 5-fluorouracil is not inferior to MALPDT. Almost identical results were found in the per protocol analysis (Table 2 and 3). A sensitivity analysis, wherein the tumours of the five patients with protocol deviations were considered as recurrences instead of lost-to-follow-up, indicated robustness of the results (Table 4 and 5).

Based on the 5-year probabilities of remaining free from recurrence, one recurrence can be prevented for every 5.6 patients (95\% CI 3.7-11.4) treated with imiquimod instead of MAL-PDT and for every 9.5 patients ( $95 \% \mathrm{Cl} 5.2-57.4$ ) treated with imiquimod instead of 5-fluorouracil. 


\section{DISCUSSION}

The results of our study showed that treatment with $5 \%$ imiquimod cream is superior to both MAL-PDT and 5-fluorouracil in treatment of SBCC, five years post-treatment, in terms of effectiveness. To our knowledge, this is the first prospective head-to-head comparison study on three different non-invasive therapies in the treatment of sBCC with a follow-up of five years. We confirmed superiority of 5\% imiquimod cream over MAL-PDT and also found evidence for superiority of imiquimod over 5-fluorouracil cream, which had not yet manifested itself at one and three years of follow-up. ${ }^{9,11}$

Our finding that imiquimod has a tumour-free survival of $80.5 \%$ after five years follow-up is comparable with other studies. A recent randomized controlled trial by Williams et al., which compared surgical excision with topical imiquimod cream in 501 patients with sBCC, reported a five-year success rate of 83.8\%. ${ }^{4}$ Only one recurrence was found between three and five years of follow-up after treatment with imiquimod, which is comparable to the low number of recurrences ( $n=2)$ found in our study in the same follow-up interval. Two other studies on imiquimod treatment for sBCC reported five-year success rates of $80.4 \%$ (95\% Cl 74.4\%$86.4 \%)$ and $77.9 \% \cdot{ }^{13,14}$

The results of this study showed that MAL-PDT has a probability of tumour-free survival of $62.7 \%$ five years post-treatment. Only one other study on MAL-PDT with a five-year follow-up is available to compare our results with. ${ }^{15}$ This study included 114 sBCC in 60 patients which showed a fiveyear success rate of 75\% (95\% Cl 64.3-83.3\%). This discrepancy may be explained by the fact that the latter study retreated patients with initial incomplete response and excluded patients that had a treatment failure at three months. This introduces bias towards a more favourable long-term result of PDT. To the best of our knowledge, no studies with long-term follow-up results after treatment with 5-fluorouracil for sBCC have been published. The effectiveness of 5-fluorouracil in the treatment of sBCC was evaluated in one study. ${ }^{16}$ This study used a longer treatment regimen of 6 to 12 weeks and reported a cure rate of $90 \%$ at 3 weeks after treatment. A longer treatment period might positively influence the results of 5 -fluorouracil.

In the European Guidelines, updated in 2014, all three studied non-invasive therapies are considered as an effective treatment for sBCC. ${ }^{17}$ Our data suggest that based on effectiveness, $5 \%$ imiquimod cream should be the non-invasive treatment of first choice. PDT and 5-fluorouracil could be reserved for situations where there is a relative or absolute contra-indication to use imiquimod. PDT may be more effective in specific subgroups of patients. We previously performed subgroup analyses indicating that in older patients with a sBCC on the lower extremities MAL-PDT was significantly more effective than imiquimod., ${ }^{9,18}$ As our study was not designed for subgroup analyses, these findings need to be validated in another study. 
Patient preferences should also be considered when choosing a therapy. A discrete choice experiment (DCE) which was performed alongside our study showed that effectiveness of a therapy was the most important driver for treatment preference. ${ }^{19}$ A study by Martin et al. also showed that 124 patients with a BCC valued a high chance of cure the most, but when the BCC was located in the head or neck region and if the BCC was recurrent, patients were willing to trade risk of recurrence for better cosmetic results. ${ }^{20}$ Two other DCEs showed that patients preferred a better cosmetic result rather than a higher level of effectiveness. It must be noted that in these studies topical treatments (MAL-PDT or imiquimod cream) were compared with surgical excision. 21,22 Furthermore, adverse events should also be taken into account. As previously reported, all therapies showed local adverse events, such as pain or skin redness. ${ }^{11}$ Patients treated with creams more often reported moderate to severe local swelling, erosion, crust formation, and itching of the skin than patients treated with MAL-PDT. However, for all studied treatments, no major adverse events were reported. ${ }^{11}$ From a cost perspective 5-fluorouracil may be considered an attractive alternative, because costs of 5-fluorouracil are much lower than costs of imiquimod. In the Netherlands, the costs of a tube of 40 grams are $€ 31.32$ compared to $€ 177.41$ for 36 sachets of imiquimod $5 \%$ cream. ${ }^{23}$ However, due the much higher risk of recurrences 5 years after treatment with 5-fluorouracil, we do not think that, from a clinical perspective, the potential higher cost savings can justify the lower effectiveness. When choosing a treatment, the various treatment aspects should be taken into account to enable patients with a sBCC to make a well-informed decision.

A limitation of this study is the loss-to-follow-up of 87 out of 601 randomized patients (14.9\%), which is a common problem in studies with long-term follow-up. For logistic reasons it was not possible to plan all control visits at exactly one, three and five years after the end of treatment. Actual dates of follow-up visits could take place before or after the pre-planned dates. For this reason the previously published three-year results show some discrepancies with the three-year results reported in the current study. In the current study, patient observations were censored at exactly 36 months after treatment (the planned date), whereas in the previous report, the actual date of the three-year follow-up visit was used for censoring when this date preceded the planned date. The absolute three-year probabilities of tumour-free survival for all three non-invasive treatments were therefore slightly underestimated compared to the absolute probability estimates in this paper. However, the estimates of the relative effectiveness of the three treatment modalities were not affected.

In conclusion, the results of this trial show that after five years of follow-up 5\% imiquimod is superior to both MAL-PDT and 5-fluorouracil in treatment of patients with primary sBCC. We therefore consider 5\% imiquimod as the first choice non-invasive treatment in most primary sBCC in terms of effectiveness. However, there is a need for multiple experiments from disparate investigators demonstrating a similar trend/outcome. 


\section{ACKNOWLEDGEMENTS}

We thank the patients who agreed to participate in this study. We thank Dr. M. de Rooij, Drs. C. Thissen, Dr. J. Rijzewijk and Drs. A. van Geest for contributing to this study. We thank all nurse practitioners, nursing staff and employees of the secretarial department of the participating hospitals. We thank Nicole Luckerhof for her excellent administrative support. We thank Kiki Frencken for her unrelenting commitment to and enthusiasm for this study.

\section{FUNDING}

The study was financed by a grant of the Netherlands Organization for Scientific Research ZonMw (08-82310-98-08626). ZonMw is a governmental institution financing research to improve health care in the Netherlands. The funding source had no role in the design or conduct of the study collection, management, analysis, or interpretation of the data, or preparation, review, or approval of the manuscript. 


\section{REFERENCES}

1. Lomas A, Leonardi-Bee J, Bath-Hextall F. A systematic review of worldwide incidence of nonmelanoma skin cancer. The British journal of dermatology. 2012;166(5):1069-1080.

2. Flohil SC, Seubring I, van Rossum MM, Coebergh JW, de Vries E, Nijsten T. Trends in Basal cell carcinoma incidence rates: a 37-year Dutch observational study. The Journal of investigative dermatology. 2013;133(4):913-918.

3. Housman TS, Feldman SR, Williford PM, et al. Skin cancer is among the most costly of all cancers to treat for the Medicare population. Journal of the American Academy of Dermatology. 2003;48(3):425429.

4. Williams HC, Bath-Hextall F, Ozolins M, et al. Surgery Versus $5 \%$ Imiquimod for Nodular and Superficial Basal Cell Carcinoma: 5-Year Results of the SINS Randomized Controlled Trial. The Journal of investigative dermatology. 2017;137(3):614-619.

5. Szeimies RM, Ibbotson S, Murrell DF, et al. A clinical study comparing methyl aminolevulinate photodynamic therapy and surgery in small superficial basal cell carcinoma (8-20 mm), with a 12-month follow-up. Journal of the European Academy of Dermatology and Venereology: JEADV. 2008;22(11):13021311.

6. Bath-Hextall F, Ozolins M, Armstrong SJ, et al. Surgical excision versus imiquimod $5 \%$ cream for nodular and superficial basal-cell carcinoma (SINS): a multicentre, non-inferiority, randomised controlled trial. Lancet Oncol. 2014;15(1):96-105.

7. Cosgarea R, Susan M, Crisan M, Senila S. Photodynamic therapy using topical 5-aminolaevulinic acid vs. surgery for basal cell carcinoma. Journal of the European Academy of Dermatology and Venereology: JEADV. 2013;27(8):980-984.

8. Roozeboom MH, Arits AH, Nelemans PJ, Kelleners-Smeets NW. Overall treatment success after treatment of primary superficial basal cell carcinoma: a systematic review and meta-analysis of randomized and nonrandomized trials. The British journal of dermatology. 2012;167(4):733-756.

9. Roozeboom MH, Arits AH, Mosterd K, et al. Three-Year Follow-Up Results of Photodynamic Therapy vs. Imiquimod vs. Fluorouracil for Treatment of Superficial Basal Cell Carcinoma: A Single-Blind, Noninferiority, Randomized Controlled Trial. The Journal of investigative dermatology. 2016;136(8):1568-1574.

10. Arits AH, Spoorenberg E, Mosterd K, Nelemans P, Kelleners-Smeets NW, Essers BA. Cost-effectiveness of topical imiquimod and fluorouracil vs. photodynamic therapy for treatment of superficial basal-cell carcinoma. The British journal of dermatology. 2014;171(6):1501-1507.

11. Arits AH, Mosterd K, Essers BA, et al. Photodynamic therapy versus topical imiquimod versus topical fluorouracil for treatment of superficial basal-cell carcinoma: a single blind, non-inferiority, randomised controlled trial. Lancet Oncol. 2013;14(7):647-654.

12. Com-Nougue C, Rodary C, Patte C. How to establish equivalence when data are censored: a randomized trial of treatments for B non-Hodgkin lymphoma. Stat Med. 1993;12(14):1353-1364.

13. Quirk C, Gebauer K, De'Ambrosis B, Slade HB, Meng TC. Sustained clearance of superficial basal cell carcinomas treated with imiquimod cream 5\%: results of a prospective 5-year study. Cutis. 2010;85(6):318-324.

14. Gollnick H, Barona CG, Frank RG, et al. Recurrence rate of superficial basal cell carcinoma following treatment with imiquimod 5\% cream: conclusion of a 5-year long-term follow-up study in Europe. European journal of dermatology: EJD. 2008;18(6):677-682. 
15. Basset-Seguin N, Ibbotson SH, Emtestam L, et al. Topical methyl aminolaevulinate photodynamic therapy versus cryotherapy for superficial basal cell carcinoma: a 5 year randomized trial. European journal of dermatology: EJD. 2008;18(5):547-553.

16. Gross K, Kircik L, Kricorian G. 5\% 5-Fluorouracil cream for the treatment of small superficial Basal cell carcinoma: efficacy, tolerability, cosmetic outcome, and patient satisfaction. Dermatologic surgery: official publication for American Society for Dermatologic Surgery [et al]. 2007;33(4):433-439; discussion 440.

17. Trakatelli M, Morton C, Nagore E, et al. Update of the European guidelines for basal cell carcinoma management. European journal of dermatology: EJD. 2014;24(3):312-329.

18. Roozeboom MH, Nelemans PJ, Mosterd K, Steijlen PM, Arits AH, Kelleners-Smeets NW. Photodynamic therapy vs. topical imiquimod for treatment of superficial basal cell carcinoma: a subgroup analysis within a noninferiority randomized controlled trial. The British journal of dermatology. 2015;172(3):739745.

19. Essers BAB, Arits AH, Hendriks MR, Mosterd K, Kelleners-Smeets NW. Patient preferences for the attributes of a non-invasive treatment for superficial Basal cell carcinoma: a discrete choice experiment. The British journal of dermatology. 2017.

20. Martin I, Schaarschmidt ML, Glocker A, et al. Patient Preferences for Treatment of Basal Cell Carcinoma: Importance of Cure and Cosmetic Outcome. Acta dermato-venereologica. 2016;96(3):355360.

21. Weston A FP. Discrete choice to experiment to derive willingness to pay for methul aminolevulinate photdynamic therapy versus simple excision surgery in basall cell carcinoma. Pharmacoeconomics. 2004;22:1195-1208.

22. Tinelli M, Ozolins M, Bath-Hextall F, Williams HC. What determines patient preferences for treating low risk basal cell carcinoma when comparing surgery vs imiquimod? A discrete choice experiment survey from the SINS trial. BMC Dermatol. 2012;12:19.

23. Medicijnkosten. www.medicijnkosten.nl, 12 September 2017. 



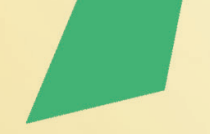

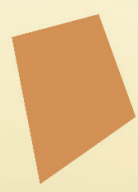

\section{CHAPTER 4.2}

\section{Comparison of long-term cosmetic outcomes for different treatments of superficial basal cell carcinoma}

M.H.E. Jansen, F.H.J. Koekelkoren, P.J. Nelemans, A.H.M.M. Arits, M.H. Roozeboom, N.W.J. Kelleners-Smeets, K. Mosterd 

The incidence of basal cell carcinoma (BCC) is rapidly increasing. ${ }^{1}$ Because also younger patients develop a BCC, cosmetic outcome is becoming more important. ${ }^{1,2}$

Between March 2008 and August 2010, 601 Dutch patients with one histologically proven primary superficial $\mathrm{BCC}$ ( $\mathrm{SBCC}$ ) were included in a randomized controlled trial comparing the effectiveness of methylaminolevulinate photodynamic therapy (MAL-PDT), imiquimod and 5-fluorouracil. ${ }^{3}$ A detailed description of the study was published previously. ${ }^{3}$ Here we report on the cosmetic outcome, evaluated at a 4-point scale (poor, fair, good and excellent) five-years after initial treatment. ${ }^{4}$ The primary outcome was the percentage with a good-excellent cosmetic outcome five-years after initial treatment, judged in live patients by an investigator blinded for treatment allocation.

The cosmetic results were dichotomized into good-excellent and poor-fair. The primary analyses were performed according to the assigned treatment (intention to treat analysis). The secondary analyses were performed according to the treatment they actually received. Patients with a recurrence were retreated and were categorized into separate groups (excision or other treatment).

Patient flow is presented in Figure 1. The distribution of baseline characteristics was similar, except for tumour size, which was smaller in the MAL-PDT-group, compared to both creams (Table 1).

In the primary analysis, good-excellent cosmetic results were found in $89.5 \%(137 / 153)$ of the sBCCs allocated to MAL-PDT, 81.8\% (121/148) in the imiquimod-and 84.7\% (133/157), in the 5-fluorouracil-group (Table 2). The relative risk (RR) of good-excellent outcome was RR 0.91, 95\% Cl 0.83-1.00, $p=0.03$ for imiquimod vs. MAL-PDT and RR 0.95 95\% Cl 0.87-1.03, $p=0.11$ ) for 5-fluorouracil vs. PDT.

In the secondary analysis including only recurrence-free tumours, cosmetic outcome was rated as good-excellent in 96.3\% (105/109) sBCCs after MAL-PDT treatment, in 83.1\% (103/124) after imiquimod treatment and in 87\% (107/123) after 5-fluorouracil treatment. Relative risks indicated a significantly higher risk of disappointing cosmetic outcome after imiquimod and 5-fluorouracil compared to MAL-PDT (Table 2). All three non-invasive options yielded a better cosmetic outcome than retreatment of recurrent BCC with excision or an alternative treatment (good-excellent cosmetic result in 75\% (66/88) and 71.4\% (10/14), respectively). Dichotomization of the results into excellent vs non-excellent (good-fair-poor) showed similar results (Table 3 ). 


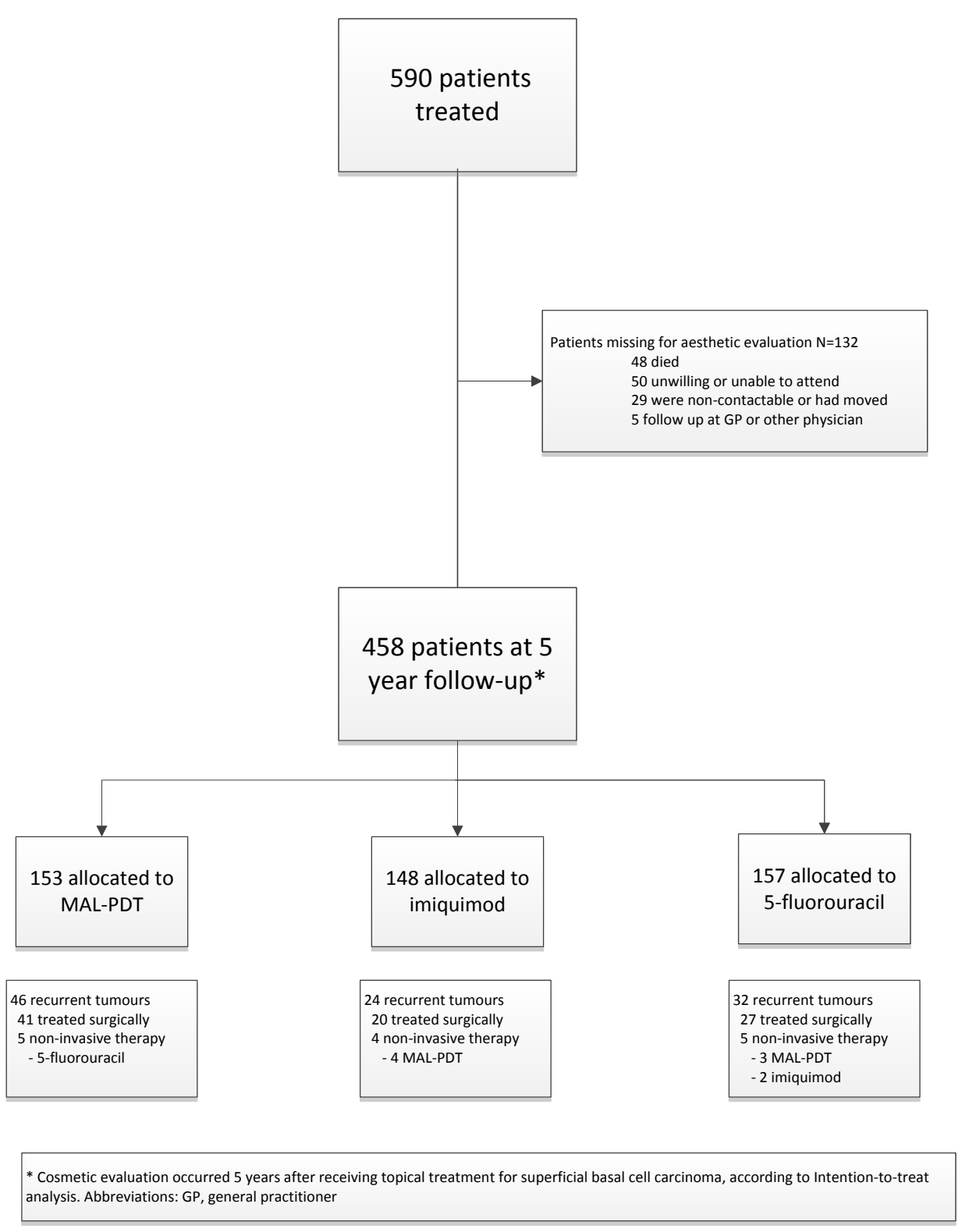

Figure 1. Flow chart. 
Table 1. Patient and tumour baseline characteristics according to treatment assigned by randomization.

\begin{tabular}{llllll}
\hline Characteristics & Value & $\begin{array}{l}\text { Total } \\
(\mathbf{n}=458)\end{array}$ & $\begin{array}{l}\text { PDT } \\
(\mathbf{n}=153)\end{array}$ & $\begin{array}{l}\text { Imiquimod } \\
(\mathbf{n}=\mathbf{1 4 8})\end{array}$ & $\begin{array}{l}\mathbf{5} \text {-FU } \\
(\mathbf{n}=\mathbf{1 5 7})\end{array}$ \\
\hline Sex & Male (n, \%) & $231(50)$ & $74(48)$ & $79(53)$ & $78(50)$ \\
& Female $(\mathrm{n}, \%)$ & $227(50)$ & $79(52)$ & $69(47)$ & $79(50)$ \\
\hline Age (median, range) & Years & $62(26-86)$ & $62(26-86)$ & $62(30-82)$ & $64(37-86)$ \\
\hline Fitzpatrick skin type (n, \%) & I & $110(24)$ & $41(27)$ & $38(26)$ & $31(20)$ \\
& II & $278(61)$ & $87(57)$ & $84(57)$ & $107(68)$ \\
& III & $20(4)$ & $6(4)$ & $8(5)$ & $6(4)$ \\
& Not recorded & $50(11)$ & $19(12)$ & $18(12)$ & $13(8)$ \\
\hline Tumour size at diagnosis & mm² & $57(5-1413)$ & $50(5-1382)$ & $63(5-1413)$ & $63(9-942)$ \\
(median, range) & & & & & \\
\hline Tumour location (n, \%) & Head/neck & $58(13)$ & $17(11)$ & $14(10)$ & $27(17)$ \\
& Trunk & $282(62)$ & $93(61)$ & $98(66)$ & $91(58)$ \\
& Upper extremities & $57(12)$ & $20(13)$ & $17(12)$ & $20(13)$ \\
& Lower extremities & $61(13)$ & $23(15)$ & $19(13)$ & $19(12)$ \\
\hline
\end{tabular}

Abbreviations: PDT, photodynamic therapy; 5-FU, 5-fluorouracil

Table 2. Percentages with good/excellent cosmetic outcome and relative risk of good or excellent outcome with 95\% confidence intervals, primary and secondary analyses.

\begin{tabular}{llll}
\hline & \multicolumn{2}{c}{ Primary analysis } & \\
& Percentage & RR $(95 \% \mathrm{Cl})$ & $p$-value \\
\hline PDT & $89.5 \%(137 / 153)$ & 1 (reference) & - \\
Imiquimod & $81.8 \%(121 / 148)$ & $0.91(0.83-1.00)$ & 0.03 \\
$5-F U$ & $84.7 \%(133 / 157)$ & $0.95(0.87-1.03)$ & 0.11 \\
\hline
\end{tabular}

Relative risk (RR) < 1 indicate decreased probability of good-excellent cosmetic outcome. Abbreviations: PDT, photodynamic therapy; 5-FU, 5-fluorouracil; $\mathrm{Cl}$, confidence interval

\begin{tabular}{llllll}
\hline & \multicolumn{5}{c}{ Secondary analysis } \\
& Percentage & RR $(95 \% \mathrm{Cl})$ & $p$-value & RR $(95 \% \mathrm{Cl})$ & $p$-value \\
\hline PDT & $96.3 \%(105 / 109)$ & $1.28(1.13-1.46)$ & $<0.001$ & 1 (reference) & - \\
Imiquimod & $83.1 \%(103 / 124)$ & $1.11(0.96-1.28)$ & 0.08 & $0.86(0.79-0.94)$ & $<0.001$ \\
5-FU & $87.0 \%(107 / 123)$ & $1.16(1.01-1.33)$ & 0.01 & $0.90(0.84-0.98)$ & 0.006 \\
SE & $75.0 \%(66 / 88)$ & 1 (reference) & - & & \\
Other & $71.4 \%(10 / 14)$ & $0.95(0.67-1.36)$ & 0.38 & & \\
\hline
\end{tabular}

Relative risk (RR) > 1 indicate increased probability of good-excellent cosmetic outcome, $R R<1$ indicate decreased probability of good-excellent cosmetic outcome. Abbreviations: SE, surgical excision; PDT, photodynamic therapy; 5-FU, 5-fluorouracil; Cl, confidence interval 
Table 3. Percentages with excellent cosmetic outcome and relative risk of non-excellent (good-fairpoor) outcome with 95\% confidence intervals, primary and secondary analyses.

\begin{tabular}{llll}
\hline & \multicolumn{2}{c}{ Primary analysis } & \\
& Percentage & RR $(95 \% \mathrm{Cl})$ & $p$-value \\
\hline PDT & $66.0 \%(101 / 153)$ & 1 (reference) & - \\
Imiquimod & $59.5 \%(88 / 148)$ & $0.90(0.76-1.07)$ & 0.12 \\
$5-F U$ & $61.1 \%(96 / 157)$ & $0.93(0.78-1.10)$ & 0.19 \\
\hline
\end{tabular}

Relative risk $(\mathrm{RR})<1$ indicate decreased probability of excellent cosmetic outcome. Abbreviations: PDT, photodynamic therapy; 5-FU, 5-fluorouracil; Cl, confidence interval

\begin{tabular}{llllll}
\hline & \multicolumn{5}{c}{ Secondary analysis } \\
& Percentage & RR $(95 \% \mathrm{Cl})$ & p-value & RR $(95 \% \mathrm{Cl})$ & p-value \\
\hline PDT & $80.7 \%(88 / 109)$ & $2.54(1.84-3.49)$ & $<0.001$ & 1 (reference) & - \\
Imiquimod & $65.3 \%(81 / 124)$ & $2.05(1.47-2.86)$ & $<0.001$ & $0.81(0.69-0.95)$ & 0.004 \\
5-FU & $67.5 \%(83 / 123)$ & $2.12(1.53-2.95)$ & $<0.001$ & $0.84(0.71-0.97)$ & 0.01 \\
SE & $31.8 \%(28 / 88)$ & 1 (reference) & - & & \\
Other & $35.7 \%(5 / 14)$ & $1.48(0.82-2.67)$ & 0.12 & & \\
\hline
\end{tabular}

Relative risk (RR) $>1$ indicate increased probability of excellent cosmetic outcome, RR $<1$ indicate decreased probability of excellent cosmetic outcome. Abbreviations: SE, surgical excision; PDT, photodynamic therapy; 5-FU, 5-fluorouracil; Cl, confidence interval

In conclusion, the results of our study showed that MAL-PDT had a statistically significant better cosmetic result compared to imiquimod and 5-fluorouracil in treatment of sBCC at five-years post-treatment when remaining recurrence-free. However, in case of treatment failure, which occurred more frequent after treatment with MAL-PDT (5-year probability of tumour-free survival of $62.7 \%$ (95\% Cl 55.3-69.2\%) vs 80.5\% for imiquimod (95\% Cl 74.0-85.6\%) and $70.0 \%$ for 5 -fluorouracil cream (95\% Cl 62.9-76.0\%)), ${ }^{5}$ retreatment with excision was associated with a lower chance of a good-excellent cosmetic outcome. The net effect is that there are no significant differences in cosmetic results between MAL-PDT, imiquimod and 5-fluorouracil when taking risk of recurrence into account. In combination with the higher effectiveness, the view of the authors is to still consider $5 \%$ imiquimod cream as first choice non-invasive treatment option for most primary sBCC.

\section{ACKNOWLEDGEMENTS}

We thank Kiki Frencken for her unrelenting commitment to and enthusiasm for this study. 


\section{REFERENCES}

1 Lomas A, Leonardi-Bee J, Bath-Hextall F. A systematic review of worldwide incidence of nonmelanoma skin cancer. The British journal of dermatology 2012; 166: 1069-80.

2 Flohil SC, Seubring I, van Rossum MM, Coebergh JW et al. Trends in Basal cell carcinoma incidence rates: a 37-year Dutch observational study. The Journal of investigative dermatology 2013; 133: 913-8.

3 Arits AH, Mosterd K, Essers BA, Spoorenberg E et al. Photodynamic therapy versus topical imiquimod versus topical fluorouracil for treatment of superficial basal-cell carcinoma: a single blind, noninferiority, randomised controlled trial. Lancet Oncol 2013; 14: 647-54.

4 Mosterd K, Arits AH, Nelemans PJ, Kelleners-Smeets NW. Aesthetic evaluation after non-invasive treatment for superficial basal cell carcinoma. Journal of the European Academy of Dermatology and Venereology: JEADV 2013; 27: 647-50.

5 Jansen MHE, Mosterd K, Arits A, Roozeboom MH et al. Five-year results of a randomized controlled trial comparing effectiveness of photodynamic therapy, topical imiquimod and topical 5-fluorouracil in patients with superficial basal cell carcinoma. The Journal of investigative dermatology 2018;138(3):527533. 

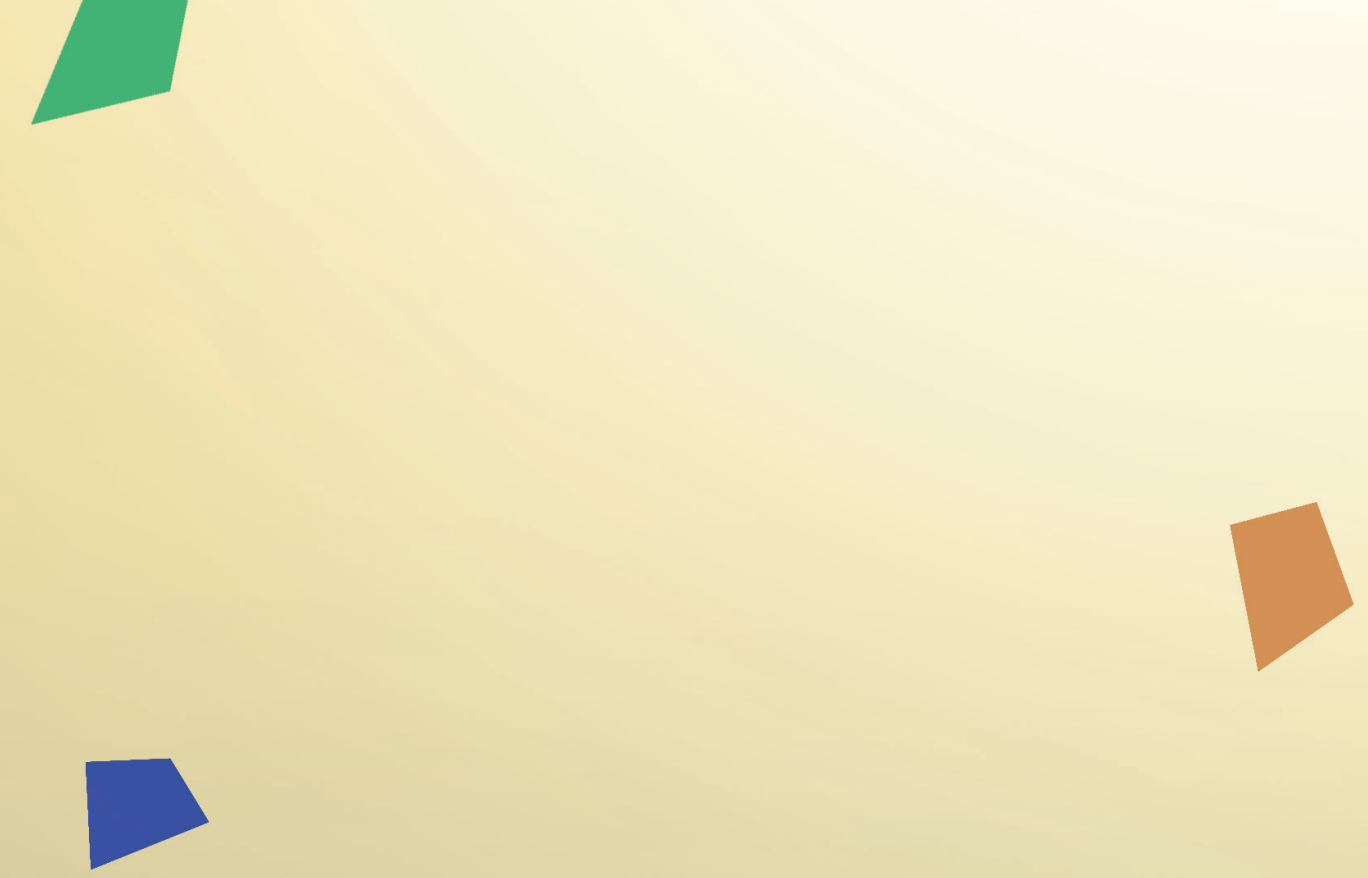

\section{CHAPTER 5}

General discussion and valorization 



\section{GENERAL DISCUSSION AND VALORIZATION}

In this chapter, the main conclusions of my research will be summarised and discussed. Moreover, the interpretation of the results, the relevance for clinicians and patients, and implications for future research will be outlined.

\section{RELEVANCE OF THE RESEARCH}

There is an enormous increase in the incidence of skin malignancies and their precursors. ${ }^{1-4}$ The incidence of basal cell carcinoma (BCC) is 1:5-6 in Dutch people and actinic keratosis (AK) is even more frequent, with a prevalence of $28 \%$ in female and $49 \%$ in male patients aged 45 years and older. ${ }^{3,5}$ This increasing incidence is probably the result of more sun exposure during leisure time, but also due to our aging population. Once a patient develops a first keratinocyte carcinoma or melanoma, they have a higher risk of developing a subsequent skin cancer in the future..$^{6-9}$

The high prevalence of patients with epidermal keratinocyte neoplasms will cause a higher burden on the dermatologic practice and therefore evaluation of current diagnostic and treatment strategies is required. More and more treatment options are available for treatment of epidermal keratinocyte neoplasms buthead-to-head comparison studies are sparse. Comparison of effectiveness, but also other factors such as cosmetic outcome, patient satisfaction and costs are important items that need to be evaluated.

This thesis describes the outcome of several clinical studies conducted on treatments of AK, Bowen's disease and superficial BCC (sBCC).

\section{TREATMENT OF ACTINIC KERATOSIS}

\section{Which treatment for $A K$ is preferred?}

For treatment of multiple lesions of AK within one distinct area field-directed therapies are suggested. ${ }^{10-13}$ Till date, head-to-head trials which compared different field-directed treatments were lacking. In a multicentre randomized controlled trial (RCT) we included 624 patients with multiple lesions of AK in the head and neck region. In this study, we showed that of four of the most frequently prescribed field-directed treatments, 5-fluorouracil (Efudix $®$ ) is the most effective treatment with a cumulative probability of treatment success of $74.7 \%$. For $5 \%$ imiquimod (Aldara $($ ), $0.015 \%$ ingenol mebutate (IM) (Picato () ), and methylaminolevulinate photodynamic therapy (MAL-PDT) this was 53.9\%, 28.9\%, and 37.7\%, respectively (chapter 2.1). 
Not only was 5-fluorouracil the most effective treatment. A cost-effectiveness analysis after one year of follow-up, showed that 5-fluorouracil was also a dominant cost-effective treatment

(chapter 2.2). The cost-effectiveness analysis included the costs of the medication, adverse events, second treatment in case of insufficient initial treatment response after one treatment cycle etcetera. The total mean costs after 12 months follow-up were $€ 421$, €710, €748, and $€ 1601$, for treatment with 5-fluorouracil, imiquimod, IM, and MAL-PDT, respectively. These differences in costs are mainly attributable to differences in treatment costs. One tube of 40 grams of 5-fluorouracil covered a treatment area up to $100 \mathrm{~cm}^{2}$. One sachet/tube of imiquimod, IM or MAL-PDT covered a treatment area of only $25 \mathrm{~cm}^{2}$. Besides the higher costs per unit, also the amount of prescribed units was higher for treatment with imiquimod, IM, and MAL-PDT.

Recently, three studies investigated the effectiveness and costs of 5-fluorouracil in AK patients compared to placebo. ${ }^{14-16}$ Pomerantz and colleagues performed a double-blinded, placebocontrolled, randomized trial in which 932 veterans, with at least 2 keratinocyte carcinomas within the past 5 years, were randomized to either 5 -fluorouracil cream or vehicle control cream. They showed that a single course of 5 -fluorouracil significantly reduced AK count (3.0 vs 8.1, p<0.001) and had higher complete clearance rates (38\% vs 17\%, $p<0.01$ ), 6 months post-randomization. They followed these patients up to a maximum of 4 years after enrolment. The median followup duration was 2.6 years in both groups. They found that there was less use of lesion directed treatments of AK in the 5 -fluorouracil group every 6-months intervals $(p<0.01) .{ }^{14}$ They also found that the single course of 5-fluorouracil reduced the risk of SCC after one year. ${ }^{17}$ Alongside the primary study, performed by Pomerantz et al., information was obtained on costs and utilization for AK and keratinocyte cancer care, up to 3 years after randomization. They concluded that after 3 years of follow-up, costs in the 5 -fluorouracil group were $\$ 771$ less per patient. ${ }^{15}$ The same group of investigators, tracked the individual AK lesions of 319 of the patients described in the trial of Pomerantz et al.. In this study, lesions were photographed and mapped to study the effect of 5-fluorouracil on prevention of new lesions. ${ }^{16}$ This prospective study showed that one course of 5-fluorouracil also significantly reduced the amount of new lesions of AK up to 36 months after treatment. The relative risk of mean number of new AK lesions per persons in 5-fluorouracil group compared to placebo was 0.65 (95\% Cl 0.51-0.83), 36 months post-treatment. ${ }^{16}$

As clinicians, we think that patients regard the most effective treatment as best therapy. However, other treatment factors, as cosmetic results, side effects, impact on quality of life, and patient satisfaction are important characteristics. Ideally, the most (cost)effective treatment includes the best results in these other factors as well.

In our study, the cosmetic outcome was assessed by the physician blinded to treatment allocation on a 4 point scale ( 1 =excellent, $2=$ good, $3=$ moderate and $4=$ poor). Changes in erythema and pigmentation were taken into account. Good to excellent cosmetic result was found in $90.3 \%$ 
of patients treated with 5-fluorouracil, in $89.7 \%, 96.6 \%$, and $95.1 \%$ of the patients treated with imiquimod, PDT and IM, respectively. We found that the cosmetic result 12 months after treatment was slightly better for MAL-PDT and IM compared to 5-fluorouracil and imiquimod. A possible explanation for a better cosmetic outcome following PDT and IM could be the fact that these treatments led to a less intense tissue response but perhaps therefore also less effective. It seems reasonable to assume that the intensity of tissue response might result in post-treatment changes, such as change in erythema and/or hypo-, hyperpigmentation, that influenced the cosmetic appearance.

To obtain information on side effects, we asked patients to complete a diary during and two weeks post-treatment. All reported side effects, such as various irritations of the skin, were well known treatment related side effects that have been described in literature. Overall, treatment with 5-fluorouracil was not associated with a higher frequency of side effects when compared with the other treatments. Patients treated with MAL-PDT reported more often pain and burning sensation in comparison with the self-applied creams/gels. Pain can be an important reason for a patient to refuse further treatment or to influence patient satisfaction.

In our study, all patients filled out the Skindex-29 at their study visits (before start, 3, and 12 months post-treatment) to assess the impact of their AK on their quality of life. Twelve months post-treatment, patients treated with 5-fluorouracil and imiquimod reported the largest decrease in scores on the Skindex-29.

Patient satisfaction also plays an important role in the decision around treatment options. As AK has a high recurrence rate, it is likely that patients will need a subsequent AK treatment in their life. In our study, a second treatment cycle was offered in all patients with treatment failure after one cycle. Refusal to undergo this second treatment was seen more frequently in the imiquimod, MAL-PDT, and IM group than in the 5-fluorouracil group. When asking patients 12 months post-treatment about their satisfaction, a larger proportion of patients treated with 5 -fluorouracil would recommend the received therapy to other people and would be willing to undergo the treatment again.

We conclude that improvement of quality of life and patient satisfaction were highest in the 5 -fluorouracil group. This may partly be explained by the fact that 5 -fluorouracil is the most effective treatment. But the high proportion of patients willing to undergo retreatment after initial treatment failure also suggests that patients treated with 5-fluorouracil may experience less inconveniences than patients treated with imiquimod, MAL-PDT, or IM, where proportions refusing retreatment were higher. The proportion of patients who would undergo PDT treatment again and would recommend it to others was lower than for the other treatments. Moreover, pain and burning sensation was more frequently reported by patients treated with 
PDT. This might indicate that pain may have influenced patient satisfaction with PDT. In our study, conventional PDT (c-PDT) was used. Nowadays, daylight-PDT (d-PDT) is available for treatment of $A K$, which is a less painful treatment. ${ }^{18,19} \mathrm{~A}$ recent meta-analysis compromising 8 studies on d-PDT and c-PDT, found that there was a similar efficacy between d-PDT and c-PDT. ${ }^{20}$ Therefore, we think that d-PDT would also have a lower effectiveness compared to 5 -fluorouracil.

Should we treat AK?

There is discussion among clinicians on whether to treat AK or not. There are different reasons to treat AK.

A reason to treat $A K$, is because $A K$ is thought to be a precursor of squamous cell carcinoma (SCC). So, treatment of AK may potentially reduce the risk on SCC development. ${ }^{10} \mathrm{~A}$ different reason to treat multiple AK (field change), is that its presence can mask the signs of a subtle keratinocyte carcinoma. Especially patients with AK are more at risk to develop a SCC or BCC compared to the general population, because all these tumours are mainly caused by UV exposure. ${ }^{21}$ After treatment of AK, non-responding lesions such as other cutaneous malignancies may become more visible for the clinician. Moreover, whether or not to treat also depends on the request of patients. Some complaints of itching, pain, bleeding or cosmetic impairment might be relieved with treatment of AK. From a cost perspective, treatment of AK might be attractive for society. Recent research showed that a single course of treatment with 5-fluorouracil cream led to cost savings related to treatment of AK and keratinocyte cancer after one and three years of follow-up. ${ }^{15}$

One could also decide to renounce treatment of AK because the potential of AK to transform into a cutaneous SCC is not evident. The recent Dutch guidelines regard AK as 'potentially premalignant'.22 Furthermore, a systematic review of Werner et al. found progression rates of 0\% to $0.075 \%$ per lesion-year, but concluded that there was insufficient reliable data to estimate the risk of progression. ${ }^{23} \mathrm{~A}$ different study, which was not included in the systematic review, found risk of progression ranging between $0.025 \%$ and $16 \%$, per year. ${ }^{24} \mathrm{~A}$ Cochrane review on interventions of AK did not find evidence at all for possible reduction in SCC after treatment of AK. ${ }^{10}$ So, the relationship between AK and progression into a SCC is still a matter of controversy.

In my opinion, in the decision on whether to treat AK or not, patients should be informed about the controversy in literature on the potential of AK to become invasive and the possible side effects of treatment. If left untreated, patients should be warned that in case of symptoms as pain, bleeding, and fast growth, they should contact their physician. Moreover, patients should be warned that AK can be regarded as a biomarker and that they should be aware of the risk to develop keratinocyte cancer. 
What are the implications for physicians and society?

In our study, described in chapter 2.1, specific lesion follow-up was performed. For all patients transparent sheets with the exact localisation of the AK lesions were drawn to monitor the lesions over time. In this study we focused on effectiveness of AK treatments, but it is of future interest to evaluate the patients after 5 years of follow-up and analyse the number of SCC developed in the treatment area. A different interesting topic for future research would be comparison of field-directed treatment with watchful waiting in patients with mild to moderate AK to study whether there are differences in risk of progression into a SCC and patient satisfaction.

Recent guidelines state no clear recommendations on the treatment of choice for AK. Based on our results, 5-fluorouracil should be considered first choice therapy as field directed treatment for AK. Our results can lead to more uniformity in treatment advise of physicians and might change recommendations in guidelines. However, there is always need for more studies from different investigators demonstrating the same results.

We included patients with all grades of AK, whereas other studies excluded patients with grade III AK. Therefore, our study population is more representative for patients seen in daily practice of the dermatologist. All follow-up visits were in accordance to the Dutch Guidelines for AK. ${ }^{22}$ By doing so, we tried to simulate daily practice as much as possible in our trial.

As $A K$ is a very frequently seen problem, it causes a significant burden on our health-care resources, which is even likely to increase over the coming years. ${ }^{25}$ Treatment of AK with the most cost-effective treatment will induce cost savings for society.

\section{Conclusion}

Based on the study in this thesis and recent literature there is no doubt: when deciding to treat AK, 5-fluorouracil cream is the first choice treatment option. It has proven to be (cost)effective, has a high patient reported satisfaction and improves of quality of life compared to imiquimod, PDT and IM. Only in patients for whom treatment with 5-fluorouracil is not possible, such as patients who are not able to apply the cream themselves, other topical treatment options might be discussed with patients.

\section{TREATMENT OF BOWEN'S DISEASE}

The incidence of most keratinocyte carcinomas is well-studied and these studies concluded that the incidence is increasing..$^{1-4}$ However, less is known about the incidence of Bowen's disease. Our study (chapter 3.1) showed that in our centre there was a trend towards an increase in the annual age-standardized incidence rates in Bowen's disease. 
There are only limited studies comparing different treatment options for the treatment of Bowen's disease. To date, guidelines state no clear recommendations on which therapy is preferred. ${ }^{26-28}$ A Cochrane review concluded that there was a lack of high quality studies on surgical excision and cream therapies for Bowen's disease. Only for the use of PDT in Bowen's disease, there was sufficient evidence. Therefore, clear recommendations could not be made. ${ }^{29}$

With the study described in chapter 3.2, we add information on non-invasive therapies in the treatment of Bowen's disease. We showed that treatment with surgical excision had the lowest chance on recurrence, with a probability of treatment failure of $4.9 \%$ up to five years posttreatment. Patients treated with 5-fluorouracil cream and PDT were more than twice as likely to receive treatment failure compared to patients treated with conventional surgical excision five years after treatment. No significant difference was found between 5-fluorouracil cream and PDT.

The study we performed was a retrospective study and therefore has potential pitfalls. Because of the non-randomized design of this study, bias due to confounding by indication could not be ruled out. An attempt was made to minimize this bias by adjustment for differences in baseline characteristics between treatment groups.

It would be of future interest to compare the most frequently prescribed therapies for Bowen's disease in a head-to-head RCT. I would suggest that at least treatment with surgical excision, 5-fluorouracil and PDT would be compared.

In our study, $7.5 \%$ of the patients were excluded because the initial biopsy showed Bowen's disease, but the excision specimen showed invasive SCC. This phenomenon is also found in literature. Moioli and colleagues described rates of $3 \%$ to $16 \%$ after conventional excision or Mohs surgery, respectively. ${ }^{30}$ Moreover, they found an odds ratio of $7.1(p<0.05)$ for having a history of keratinocyte carcinoma in patients with this sampling error. ${ }^{30} \mathrm{~A}$ different study showed that location on ears, nose, lips, and eyelids and a tumour diameter of $>10 \mathrm{~mm}$ could be predictors of this so-called 'upstaging. ${ }^{31}$ As a biopsy only represents a small part of the tumour, clinicians should be aware of this sampling error.

Besides the risk of sampling error, there is also the risk of a recurrent lesion that transforms into a SCC over time, as Bowen's disease is regarded a precursor of SCC. Studies show diverging rates of 2.3-12.6\% after treatment with excision, cryotherapy or PDT.32,33 In our study, 8 recurrent lesions ( $<1 \%$ ) progressed into an invasive SCC, after treatment with 5-fluorouracil or PDT. Transformation of recurrent tumours into SCC following surgical excision was not observed. An explanation for not finding any transformation of a recurrent tumour into SCC in the surgical excision group, might be that the treating physicians might have had a higher clinical suspicion of a SCC and therefore choose a surgical treatment instead of a non-invasive treatment. 
What are the implications for physicians and patients?

Overall, surgical excision remains a first choice treatment option in terms of effectiveness. However, in my opinion, non-invasive treatment modalities might be a good alternative. Especially, as there is little substantial evidence in literature on the progression rates of Bowen's disease into an invasive cutaneous SCC. Non-invasive therapies are well established for the treatment of other epidermal neoplasms, such as AK and sBCC.

Cosmetic results and patient preferences are also important to take into account when choosing a therapy besides considering the effectiveness of treatments. Patients should be informed about all options.

Nevertheless, when considering a non-invasive therapy clinicians should be aware of the possibility that a biopsy may be prone to sampling error. Factors as tumour size, tumour localisation, clinical suspicion on a SCC, and history of skin cancer should also be considered in deciding on treatment.

\section{TREATMENT OF SUPERFICIAL BASAL CELL CARCINOMA}

Surgical excision is generally accepted as most effective therapy for the treatment of sBCC. However, in situations where surgical excision is regarded as contraindicated, impractical, or disfavoured by the patient himself, other therapy options can be discussed. Nowadays, there is the tendency to use non-invasive therapies more frequently.

For the treatment of sBCC a variety of therapies is available. These treatments and their associated advantages, side effects, and costs pose a challenge for physicians to adequately educate patients about their treatment options. A recent qualitative study underlined the preference of BCC patients to receive all relevant information about their treatment options. ${ }^{34}$

To assess what patients value about therapies, a discrete choice experiment (DCE) can be performed. A recent review of several DCEs for the treatment of BCC, showed that most patients valued low risk of recurrence and cosmetic result the most. ${ }^{35}$ These factors play an important role in shared decision making. Head-to-head studies with long-term follow-up regarding recurrence rates and cosmetic results are pivotal. Only a few studies describe longterm follow-up results of non-invasive therapies for treatment of sBCC. ${ }^{36-39}$

With this background, a RCT composing 601 patients with a primary sBCC treated with MALPDT, 5-fluorouracil, or imiquimod with 5 years of follow-up was performed (chapter 4.1). The 
one and three year follow-up results showed that 5-fluorouracil was non-inferior and imiquimod was superior compared to MAL-PDT, but no conclusions could be drawn between 5-fluorouracil and imiquimod. ${ }^{40,41}$ We assessed the efficacy five years post-treatment. We found that after five years of follow-up the differences in recurrence rates between the three therapies became larger and that imiquimod cream was superior compared to both 5-fluorouracil and MAL-PDT. The probability of tumour-free survival 5-years after treatment was $80.5 \%$ for imiquimod, 70.0\% for 5 -fluorouracil and $62.7 \%$ for MAL-PDT. So, in terms of efficacy, 5\% imiquimod cream should be considered first choice non-invasive treatment option in most primary sBCC.

As written in the DCE, patients also valued cosmetic outcome as an important factor. Next to the efficacy, we assessed the cosmetic outcome five years post-treatment, in the same study as described above (chapter 4.2). The cosmetic outcome was judged by a physician blinded to treatment allocation at a 4-point scale (poor, fair, good and excellent) five-years after initial treatment. Here we found that MAL-PDT had a better cosmetic result compared to imiquimod and 5-fluorouracil in treatment of sBCC at five-years post-treatment when remaining recurrence-free. Retreatment of a recurrence with surgical excision or an alternative treatment showed a worse cosmetic outcome. So, patients are facing a trade-off. Only considering the risk of recurrence, imiquimod would be first choice treatment. In terms of cosmetic result, patients who respond well to treatment with MAL-PDT and 5-fluorouracil can expect better cosmetic outcome compared with imiquimod. However, taking into account that treatment of the recurrence with surgical excision has a lower chance on a good cosmetic result, the net effect was that there were no significant differences in cosmetic results, as treatment with MAL-PDT and 5-fluoroucil recurrences occur more frequently.

What are the implications for physicians and patients?

In terms of effectiveness, surgical excision is a first choice treatment option. However, I think patients should also carefully be informed on alternative treatment options as non-invasive treatments, and the advantages and disadvantages of all options should be explained to allow patients to make a well informed decision. When considering a non-invasive therapy for treatment of sBCC, I would primarily advise 5\% imiquimod cream, based on its efficacy up to five years post-treatment. The fact that it is a home-based treatment were patients should apply the cream themselves could be an advantage for some patients, where it is a disadvantage for patients not able to do so.

The studies presented in this thesis, add evidence on different aspects of treatment options for sBCC. It would be of future interest to develop a decision aid on different treatment options and explanation of the different aspects. This would be very useful for both patients and physicians. 


\section{PREVENTION}

The main risk factor for the development of AK, Bowen's disease and SBCC is extensive sun exposure. The studies presented in thesis focussed on the improvement of various treatments for epidermal keratinocyte neoplasms. Of course, one should not forget that preventing the occurrence of skin cancer is just as important or even more important. Therefore, extensive education of patients is essential. This education should not only include raising awareness on the risks of the sun and consequently the risk on skin cancer, but should also encompass promotion of sun-protective behaviour. Sun protection measures as primary prevention is proven to be effective. ${ }^{42}$

To conclude, I would like to cite a song of 1999 from Baz Luhrmann (Everybody's free (to wear sunscreen)): 'Ladies and Gentlemen of the class of '99. Wear sunscreen. If I could offer you only one tip for the future, sunscreen would be it. The long term benefits of sunscreen have been proved by scientists whereas the rest of my advice has no basis more reliable than my own meandering experience. ... Be careful whose advice you buy, but, be patient with those who supply it. Advice is a form of nostalgia, dispensing it is a way of fishing the past from the disposal, wiping it off, painting over the ugly parts and recycling it for more than it's worth. But trust me on the sunscreen.'

\section{CONCLUSIONS}

In conclusion, the research presented in this thesis showed that for the treatment of AK, 5 -fluorouracil is not only the most effective, but also the most cost-effective therapy. Moreover, it is a treatment that is well accepted and regarded by patients.

For treatment of Bowen's disease, surgery remains gold standard. However, more direct comparisons between non-invasive therapies are needed to determine the best therapeutic approach and the most patient-preferred treatment.

For non-invasive treatment of sBCC, we showed that 5\% imiquimod cream is statistically significant more effective compared to two other non-invasive therapies. When considering the effectiveness and hereby the risk of retreatment with surgical excision in case of treatment failure, there were no significant differences in cosmetic results. Therefore, 5\% imiquimod cream is considered as the first choice non-invasive therapy for sBCC. 


\section{REFERENCES}

1. Flohil SC, Seubring I, van Rossum MM, Coebergh JW, de Vries E, Nijsten T. Trends in Basal cell carcinoma incidence rates: a 37-year Dutch observational study. The Journal of investigative dermatology. 2013;133(4):913-918.

2. Hollestein LM, de Vries E, Nijsten T. Trends of cutaneous squamous cell carcinoma in the Netherlands: increased incidence rates, but stable relative survival and mortality 1989-2008. European journal of cancer (Oxford, England: 1990). 2012;48(13):2046-2053.

3. Flohil SC, de Vries E, Neumann HA, Coebergh JW, Nijsten T. Incidence, prevalence and future trends of primary basal cell carcinoma in the Netherlands. Acta dermato-venereologica. 2011;91(1):24-30.

4. Madan V, Lear JT, Szeimies RM. Non-melanoma skin cancer. Lancet. 2010;375(9715):673-685.

5. Flohil SC, van der Leest RJ, Dowlatshahi EA, Hofman A, de Vries E, Nijsten T. Prevalence of actinic keratosis and its risk factors in the general population: the Rotterdam Study. The Journal of investigative dermatology. 2013;133(8):1971-1978.

6. van der Leest RJT, Hollestein LM, Liu L, Nijsten T, de Vries E. Risks of different skin tumour combinations after a first melanoma, squamous cell carcinoma and basal cell carcinoma in Dutch populationbased cohorts: 1989-2009. Journal of the European Academy of Dermatology and Venereology: JEADV. 2018;32(3):382-389.

7. Flohil SC, Koljenovic S, de Haas ER, Overbeek LI, de Vries E, Nijsten T. Cumulative risks and rates of subsequent basal cell carcinomas in the Netherlands. The British journal of dermatology. 2011;165(4):874-881.

8. van der Leest RJ, Flohil SC, Arends LR, de Vries E, Nijsten T. Risk of subsequent cutaneous malignancy in patients with prior melanoma: a systematic review and meta-analysis. Journal of the European Academy of Dermatology and Venereology: JEADV. 2015;29(6):1053-1062.

9. van der Leest RJ, Liu L, Coebergh JW, et al. Risk of second primary in situ and invasive melanoma in a Dutch population-based cohort: 1989-2008. The British journal of dermatology. 2012;167(6):13211330.

10. Gupta AK, Paquet M, Villanueva E, Brintnell W. Interventions for actinic keratoses. The Cochrane database of systematic reviews. 2012;12:Cd004415.

11. de Berker D, McGregor JM, Mohd Mustapa MF, Exton LS, Hughes BR. British Association of Dermatologists' guidelines for the care of patients with actinic keratosis 2017. The British journal of dermatology. 2017;176(1):20-43.

12. Werner RN, Stockfleth E, Connolly SM, et al. Evidence- and consensus-based (S3) Guidelines for the Treatment of Actinic Keratosis - International League of Dermatological Societies in cooperation with the European Dermatology Forum - Short version. Journal of the European Academy of Dermatology and Venereology: JEADV. 2015;29(11):2069-2079.

13. Beljaards RC, van der Sande A. Update richtlijn actinische keratosen 2017. Nederlands Tijdschrift voor Dermatologie en Venereologie. 2017;27(04):190-192.

14. Pomerantz H, Hogan D, Eilers D, et al. Long-term Efficacy of Topical Fluorouracil Cream, $5 \%$, for Treating Actinic Keratosis: A Randomized Clinical Trial. JAMA dermatology. 2015.

15. Yoon J, Phibbs CS, Chow A, Weinstock MA. Impact of Topical Fluorouracil Cream on Costs of Treating Keratinocyte Carcinoma (Nonmelanoma Skin Cancer) and Actinic Keratosis. Journal of the American Academy of Dermatology. 2018;79(3):501-507 e502. 
16. Walker JL, Siegel JA, Sachar M, et al. 5-Fluorouracil for Actinic Keratosis Treatment and Chemoprevention: A Randomized Controlled Trial. The Journal of investigative dermatology. 2017;137(6):1367-1370.

17. Weinstock MA, Thwin SS, Siegel JA, et al. Chemoprevention of Basal and Squamous Cell Carcinoma With a Single Course of Fluorouracil, 5\%, Cream: A Randomized Clinical Trial. JAMA dermatology. 2018.

18. Lacour JP, Ulrich C, Gilaberte Y, et al. Daylight photodynamic therapy with methyl aminolevulinate cream is effective and nearly painless in treating actinic keratoses: a randomised, investigator-blinded, controlled, phase III study throughout Europe. Journal of the European Academy of Dermatology and Venereology: JEADV. 2015;29(12):2342-2348.

19. Philipp-DormstonWG, Sanclemente G, Torezan L, et al. Daylight photodynamic therapy with MAL cream for large-scale photodamaged skin based on the concept of 'actinic field damage': recommendations of an international expert group. Journal of the European Academy of Dermatology and Venereology: JEADV. 2016;30(1):8-15.

20. Zhao W, Guan M, Nong X, Li Q, Chen Z. The safety and efficacy of daylight photodynamic therapy in the treatment of actinic keratoses: a systematic review and meta-analysis. International journal of dermatology. 2019;58(2):159-166.

21. Chen GJ, Feldman SR, Williford PM, et al. Clinical diagnosis of actinic keratosis identifies an elderly population at high risk of developing skin cancer. Dermatologic surgery: official publication for American Society for Dermatologic Surgery [et al]. 2005;31(1):43-47.

22. Venereologie NVvDe. Guideline Actinic Keratosis. 2017; https://www.huidarts.info.

23. Werner RN, Sammain A, Erdmann R, Hartmann V, Stockfleth E, Nast A. The natural history of actinic keratosis: a systematic review. The British journal of dermatology. 2013;169(3):502-518.

24. Glogau RG. The risk of progression to invasive disease. Journal of the American Academy of Dermatology. 2000;42(1 Pt 2):23-24.

25. Stockfleth E. The importance of treating the field in actinic keratosis. Journal of the European Academy of Dermatology and Venereology. 2017;31:8-11.

26. Morton CA, Birnie AJ, Eedy DJ. British Association of Dermatologists' guidelines for the management of squamous cell carcinoma in situ (Bowen's disease) 2014. The British journal of dermatology. 2014;170(2):245-260.

27. Bonerandi J J, Beauvillain C, Caquant L, et al. Guidelines for the diagnosis and treatment of cutaneous squamous cell carcinoma and precursor lesions. Journal of the European Academy of Dermatology and Venereology: JEADV. 2011;25 Suppl 5:1-51.

28. Szeimies RM, Karrer S, Backer H. [Therapeutic options for epithelial skin tumors. Actinic keratoses, Bowen disease, squamous cell carcinoma, and basal cell carcinoma]. Der Hautarzt; Zeitschrift fur Dermatologie, Venerologie, und verwandte Gebiete. 2005;56(5):430-440.

29. Bath-Hextall FJ, Matin RN, Wilkinson D, Leonardi-Bee J. Interventions for cutaneous Bowen's disease. The Cochrane database of systematic reviews. 2013;6:Cd007281.

30. Moioli EK, Hsieh C, Tisch A, Bolotin D. Histologic Status of Squamous Cell Carcinoma In Situ After Diagnostic Biopsy in Immunocompetent and Immunosuppressed Patients. Dermatologic surgery: official publication for American Society for Dermatologic Surgery [et al]. 2018;44(3):341-349.

31. Eimpunth S, Goldenberg A, Hamman MS, et al. Squamous Cell Carcinoma In Situ Upstaged to Invasive Squamous Cell Carcinoma: A 5-Year, Single Institution Retrospective Review. Dermatologic surgery: official publication for American Society for Dermatologic Surgery [et al]. 2017;43(5):698-703.

32. Overmark M, Koskenmies S, Pitkanen S. A Retrospective Study of Treatment of Squamous Cell Carcinoma In situ. Acta dermato-venereologica. 2016;96(1):64-67. 
33. Ratour-Bigot C, Chemidling M, Montlahuc C, et al. Squamous Cell Carcinoma Following Photodynamic Therapy for Cutaneous Bowen's Disease in a Series of 105 Patients. Acta dermato-venereologica. 2016;96(5):658-663.

34. van Egmond S, Wakkee M, Droger M, et al. Needs and preferences of patients regarding basal cell carcinoma and cutaneous squamous cell carcinoma care: a qualitative focus group study. The British journal of dermatology. 2018.

35. Neal DE, Feit EM, Etzkorn JR. Patient Preferences for the Treatment of Basal Cell Carcinoma: A Mapping Review of Discrete Choice Experiments. Dermatologic surgery: official publication for American Society for Dermatologic Surgery [et al]. 2018;44(8):1041-1049.

36. Williams HC, Bath-Hextall F, Ozolins M, et al. Surgery Versus $5 \%$ Imiquimod for Nodular and Superficial Basal Cell Carcinoma: 5-Year Results of the SINS Randomized Controlled Trial. The Journal of investigative dermatology. 2017;137(3):614-619

37. Quirk C, Gebauer K, De'Ambrosis B, Slade HB, Meng TC. Sustained clearance of superficial basal cell carcinomas treated with imiquimod cream 5\%: results of a prospective 5-year study. Cutis. 2010;85(6):318-324.

38. Gollnick H, Barona CG, Frank RG, et al. Recurrence rate of superficial basal cell carcinoma following treatment with imiquimod 5\% cream: conclusion of a 5-year long-term follow-up study in Europe. European journal of dermatology: EJD. 2008;18(6):677-682.

39. Basset-Seguin N, Ibbotson SH, Emtestam L, et al. Topical methyl aminolaevulinate photodynamic therapy versus cryotherapy for superficial basal cell carcinoma: a 5 year randomized trial. European journal of dermatology: EJD. 2008;18(5):547-553.

40. Arits AH, Mosterd K, Essers BA, et al. Photodynamic therapy versus topical imiquimod versus topical fluorouracil for treatment of superficial basal-cell carcinoma: a single blind, non-inferiority, randomised controlled trial. Lancet Oncol. 2013;14(7):647-654.

41. Roozeboom MH, Arits AH, Mosterd K, et al. Three-Year Follow-Up Results of Photodynamic Therapy vs. Imiquimod vs. Fluorouracil for Treatment of Superficial Basal Cell Carcinoma: A Single-Blind, Noninferiority, Randomized Controlled Trial. The Journal of investigative dermatology. 2016;136(8):1568-1574.

42. Watts CG, Drummond M, Goumas C, et al. Sunscreen Use and Melanoma Risk Among Young Australian Adults. JAMA dermatology. 2018;154(9):1001-1009. 


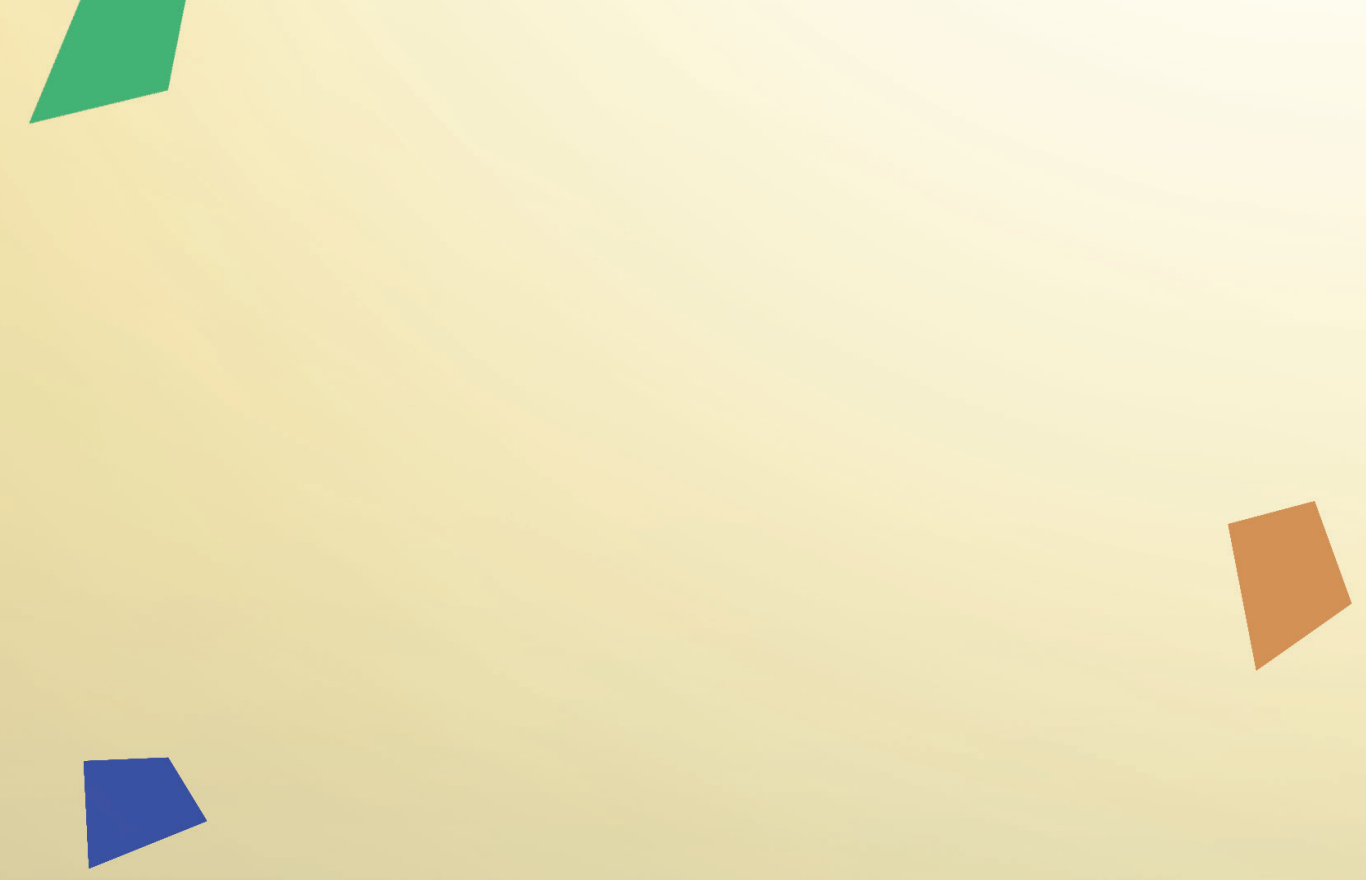

\section{CHAPTER 6}

Summary Samenvatting 



\section{SUMMARY}

The increase in patients with skin cancer and its precursors has ensured more evaluation of current treatment strategies. This thesis focuses on the various treatments of three common skin disorders: actinic keratosis (AK), Bowen's disease and superficial basal cell carcinoma (sBCC).

Chapter 1 provides a general introduction on the three different epidermal keratinocyte neoplasms, in which epidemiology, clinic, pathology, and different treatment options are explained. In addition, the objectives of the thesis are described in this chapter.

Chapter 2 focuses on the treatment of AK. The results of the AKTI-trial are presented in chapter 2.1. This trial is a prospective randomized multicentre study in which the four most common field-directed treatments of AK are compared with each other. Between November 2014 and March 2017, 624 patients were enrolled in four hospitals in the southern part of the Netherlands. Patients were randomly assigned to one of the treatments: 5\% 5-fluorouracil cream (2 times a day for 4 weeks), 5\% imiquimod cream (3 days per week (mon-wed-fri) for 4 weeks), methylaminolevulinate (MAL-) photodynamic therapy (PDT) (one session) or $0.015 \%$ ingenol mebutate (IM) gel (3 consecutive days). The primary outcome measure was the proportion of patients with $\geq 75 \%$ reduction in the number of AKs 12 months after treatment compared to the start of the study. We found that 12 months post-treatment 5-fluorouracil cream was the most effective treatment with a cumulative probability of remaining free from treatment failure of 74.7\% (95\% confidence interval (CI) 66.8-81.0). Treatment success with imiquimod, PDT and IM was significantly lower compared to 5-fluorouracil with a cumulative probability of remaining free from treatment failure of 53.9\% (95\% Cl 45.4-61.6), 37.7\% (95\% Cl 30.0-45.3), and 28.9\% (95\% Cl 21.8-36.3), respectively.

Moreover, we found that side effects were comparable between the four treatment groups. Compliance was higher in the IM group (98.7\%) than in the 5-fluorouracil group (88.7\%) and the imiquimod group (88.2\%). Patient satisfaction and increase in health-related quality of life were highest in the 5-fluorouracil group. Good to excellent cosmetic outcome was most often observed in the PDT and IM group (96.6\% and $95.1 \%$, respectively) compared to $90.3 \%$ and $89.7 \%$ in the 5 -fluorouracil and imiquimod group, respectively.

Due to the increasing incidence, the recommended treatment of AK results in a considerable socio-economic burden for (dermatological) healthcare. Considering the impact on healthcare costs, it is important to know which treatment for AK is the most cost-effective. Chapter $\mathbf{2 . 2}$ describes the results of the cost-effectiveness analysis. An economic evaluation was performed from a healthcare perspective to determine which commonly prescribed field-directed 
treatment is the most cost-effective. Real resource consumption was measured during the AKTI-trial. All pre-treatment costs, treatment costs, and post-treatments costs were collected. We found that the total mean costs for treatment with 5-fluorouracil were significantly lower (€433), compared to €728, €775 and €1621 for treatment with imiquimod, IM and MAL-PDT, respectively. With these results, we concluded that 5 -fluorouracil was a dominant cost-effective treatment compared to the other treatments, 12 months post-treatment as it was more effective and cost-saving.

In chapter $\mathbf{3}$ a different epidermal keratinocyte neoplasm is described: Bowen's disease. There are many studies that focus on the incidence of various forms of skin cancer. However, only few data have been published on the incidence of Bowen's disease. Chapter 3.1 describes the results of our study on the incidence of Bowen's disease in the Maastricht University Medical Centre between 2003 and 2013. The results showed a statistically significant trend with a substantial increase of histologically confirmed Bowen's disease between 2003 and 2013, in both men and women. In chapter 3.2, the clinical effectiveness of three commonly used treatments for Bowen's disease was studied in a retrospective study. A total of 608 patients with 841 histologically confirmed tumours of Bowen's disease diagnosed between 1 January 2008 and 31 December 2013 were included. The results showed that the risk for treatment failure in patients treated with 5-fluorouracil cream and PDT was more than twice as high compared to patients treated with conventional surgical excision five years after treatment. No significant difference was found between 5-fluorouracil cream and PDT.

Chapter 4 is subdivided into two sections in which different aspects of treatments of sBCC are presented.

A previous study on the effectiveness of different non-invasive treatments of sBCC showed that imiquimod and 5-fluorouracil were superior to MAL-PDT, 1 and 3 years post-treatment. However, no definite conclusion could be drawn about the superiority of imiquimod compared to 5-fluorouracil. In chapter 4.1 we present the five-year follow-up results of this study. Our results showed that treatment with $5 \%$ imiquimod five years after treatment is superior to both MALPDT and 5-fluorouracil cream with a probability of tumour-free survival of $80.5 \%$ for imiquimod (95\% Cl 74.0-85.6), 62.7\% (95\% Cl 55.3-69.2) and 70.0\% (95\% Cl 62.9-76.0) for MAL-PDT and 5 -fluorouracil, respectively. Therefore, we consider $5 \%$ imiquimod cream as the first choice non-invasive treatment for most primary sBCCs.

The incidence of sBCC is increasing, especially among younger patients. In those patients, cosmetic outcome is probably even more important. In Chapter 4.2 the cosmetic results of the study described in chapter 4.1 are analysed. Five years after treatment, the cosmetic result was assessed by an independent researcher on a four-point scale (excellent, good, moderate and 
poor). Good to excellent cosmetic results were found in $89.5 \%$ (137/153) of the sBCCs allocated to MAL-PDT, 81.8\% (121/148) in the imiquimod- and 84.7\% (133/157), in the 5-fluorouracilgroup. So, the results show that MAL-PDT had a significantly better cosmetic outcome compared to imiquimod and 5-fluorouracil. However, retreatment with surgery in the case of treatment failure led to a lower chance of a good cosmetic result. As there was significantly more frequent treatment failure after PDT, there were on the whole no significant differences in terms of cosmetic result. In our opinion 5\% imiquimod cream is therefore still non-invasive treatment of first choice in most primary sBCCs.

Chapter $\mathbf{5}$ concludes with the interpretation of the results of studies done in this thesis and discusses the position of these results within the current daily practice. 



\section{SAMENVATTING}

De toename van patiënten met huidkanker en voorlopers daarvan, heeft geleid tot meer onderzoek naar behandelingen van deze aandoeningen.

Dit proefschrift richt zich op de diverse behandelingen van drie veelvoorkomende huidaandoeningen: actinische keratose (AK), Morbus Bowen en het superficieel basaalcelcarcinoom (sBCC).

Hoofdstuk 1 is een algemene inleiding over de drie verschillende aandoeningen, waarin epidemiologie, kliniek, pathologie en verschillende behandelopties worden uitgelegd. Daarnaast worden in dit hoofdstuk de doelstellingen van het proefschrift beschreven.

Hoofdstuk 2 richt zich op de behandeling van AK. In hoofdstuk 2.1 worden de resultaten van de AKTI-trial gepresenteerd. Dit is een prospectieve gerandomiseerde multicenter studie waarbij de vier meest voorkomende veldbehandeling van AK met elkaar vergeleken werden. Tussen november 2014 en maart 2017 werden 624 patiënten geïncludeerd, verdeeld over 4 ziekenhuizen in zuid Nederland. Patiënten werden at random toegewezen aan één van de behandelingen: 5\% 5-fluorouracil crème (2 keer per dag gedurende 4 weken), 5\% imiquimod crème ( 3 dagen per week (ma-wo-vrij) gedurende 4 weken), methylaminolevulinaat (MAL-) fotodynamische therapie (PDT) (één sessie) of $0.015 \%$ ingenol mebutate (IM) gel (3 achtereenvolgende dagen). De primaire uitkomstmaat was de proportie patiënten met $\geq 75 \%$ reductie van het aantal AK's 12 maanden na behandeling ten opzichte van het begin van de studie. We vonden dat 12 maanden na behandeling 5-fluorouracil crème de meest effectieve behandeling was met een behandelsucces van 74.7\% (95\% betrouwbaarheids interval (BI) 66.881.0). Het behandel succes van imiquimod, PDT en IM was significant lager met 53.9\% (95\% BI 45.4-61.6), 37.7\% (95\% BI 30.0-45.3), en 28.9\% (95\% BI 21.8-36.3), respectievelijk.

Daarnaast vonden we dat de bijwerkingen vergelijkbaar waren tussen de vier behandelgroepen. In de IM-groep was de therapietrouw hoger (98.7\%) dan in de 5-fluorouracil-groep (88.7\%) en de imiquimod-groep (88.2\%). De tevredenheid van de patiënt en de toename van de gezondheidsgerelateerde kwaliteit van leven waren het hoogst in de 5-fluorouracil groep. Een goed en uitstekend cosmetisch resultaat werd het vaakst gevonden in de PDT- en IM-groep (respectievelijk 96.6\% en 95.1\%) vergeleken met 90.3\% en $89.7 \%$ in de 5-fluorouracil- en imiquimod-groep, respectievelijk.

Door de toenemende incidentie, resulteert de behandeling van AK in een aanzienlijke socioeconomische belasting voor de (dermatologische) gezondheidszorg. Voor het gevolg op de kosten van de gezondheidszorg is het belangrijk om te weten welke behandeling van AK het meest 
kosteneffectief is. In hoofdstuk 2.2 worden de resultaten van de kosten-effectiviteitsanalyse beschreven. Een economische evaluatie vanuiteen gezondheidszorgperspectiefwerd uitgevoerd om te bepalen welke meest voorgeschreven veldbehandeling de meest kosteneffectieve therapie is. Hierbij werd het daadwerkelijke middelenverbruik gemeten gedurende de AKTI-trial. Alle voorbehandelingskosten, behandelkosten en kosten voor nabehandeling werden verzameld. We vonden dat de totale gemiddelde kosten voor 5 -fluorouracil aanzienlijk lager waren (€ 433), vergeleken met $€ 728$, $€ 775$ en $€ 1621$ voor respectievelijk imiquimod, IM en MAL-PDT. De resultaten toonden aan dat 5-fluorouracil een dominante kosteneffectieve behandeling was in vergelijking met de andere behandelingen, 12 maanden na behandeling. Dus, 5-fluorouracil was zowel effectiever als kostenbesparend.

In hoofdstuk 3 wordt een andere voorloper van huidkanker beschreven: M. Bowen. Tegenwoordig zijn er veel studies die zich richten op de incidentie van diverse vormen van huidkanker. Er is echter geen onderzoek naar de incidentie van M. Bowen. In hoofdstuk 3.1 worden de resultaten beschreven van het onderzoek naar de stijging in incidentie van M. Bowen in het Maastricht Universitair Medisch Centrum tussen 2003 en 2013. De resultaten toonden een statistisch significante trend met een aanzienlijke toename van de histologisch bevestigde M. Bowen tussen 2003 en 2013, bij zowel mannen als vrouwen. In hoofdstuk $\mathbf{3 . 2}$ werd middels een retrospectieve studie de klinische effectiviteit van drie veelgebruikte behandelingen voor M. Bowen geanalyseerd. In totaal werden er bij 608 patiënten 841 tumoren van histologisch bewezen M. Bowen geincludeerd die gediagnosticeerd waren tussen 1 januari 2008 en 31 december 2013. De resultaten van deze studie lieten zien dat 5 jaar na behandeling, patiënten behandeld met 5-fluorouracil crème en PDT meer dan twee keer zoveel kans hadden op behandelfalen vergeleken met patiënten behandeld met conventionele chirurgische excisie. Er werd geen significant verschil gevonden tussen 5-fluorouracil crème en PDT.

Hoofdstuk 4 is onderverdeeld in twee secties waarin de verschillende aspecten van behandeling van het sBCC worden gepresenteerd.

Een eerdere studie naar de effectiviteit van verschillende niet-invasieve behandelingen van het sBCC liet zien dat na 1 en 3 jaar 5\% imiquimod en 5\% 5-fluorouracil superieur waren aan MAL-PDT. Er kon echter geen definitieve conclusie getrokken worden over de superioriteit van imiquimod ten opzichte van 5-fluorouracil. In hoofdstuk 4.1 presenteren we de vijf jaar follow-up resultaten van deze studie waaruit blijkt dat behandeling met 5\% imiquimod superieur is ten opzichte van zowel MAL-PDT als 5-fluorouracil crème met een kans op tumorvrije survival van 80.5\% voor imiquimod (95\% BI 74.0-85.6), 62.7\% (95\% BI 55.3-69.2) en 70.0\% (95\% BI 62.976.0) voor MAL-PDT en 5-fluorouracil, respectievelijk. Daarom beschouwen we $5 \%$ imiquimod crème als eerste keus non-invasieve behandeling voor de meeste primaire sBCC's. 
De incidentie van sBCC stijgt, met name onder jongere patiënten. Bij deze patiënten is mogelijk het cosmetisch resultaat van behandelingen belangrijker. Hoofdstuk 4.2 beschrijft het cosmetisch resultaat na behandeling van bovengenoemde studie uit hoofdstuk 4.1. Vijf jaar na behandeling werd het cosmetisch resultaat beoordeeld door een onafhankelijk onderzoeker op een vier-puntsschaal (excellent, goed, matig en slecht). Een goed tot uitstekend cosmetisch resultaat werd gevonden in 89.5\% (137/153) van de sBCC's in de MAL-PDT-groep, in 81.8\% (121/148) in de imiquimod-groep en in $84.7 \%$ (133/157) in de 5-fluorouracil-groep. Dus, de resultaten lieten zien dat MAL-PDT een statistisch significant beter cosmetisch resultaat had vergeleken met imiquimod en 5-fluorouracil. Echter, in het geval van behandelfalen leidde herbehandeling met chirurgie tot een lagere kans op een goed cosmetisch resultaat. Zoals in hoofdstuk 4.1 beschreven, was er significant vaker behandelfalen na PDT, waardoor er netto geen significante verschillen qua cosmetiek waren. Onze mening blijft dan ook dat gezien de hogere effectiviteit, 5\% imiquimod crème eerste keus non-invasieve behandeling bij de meeste primaire sBCCs is.

Hoofdstuk 5 besluit met de interpretatie van de resultaten van de studies in dit proefschrift en bediscussieert welke plaats deze resultaten innemen in de dagelijkse praktijk. 

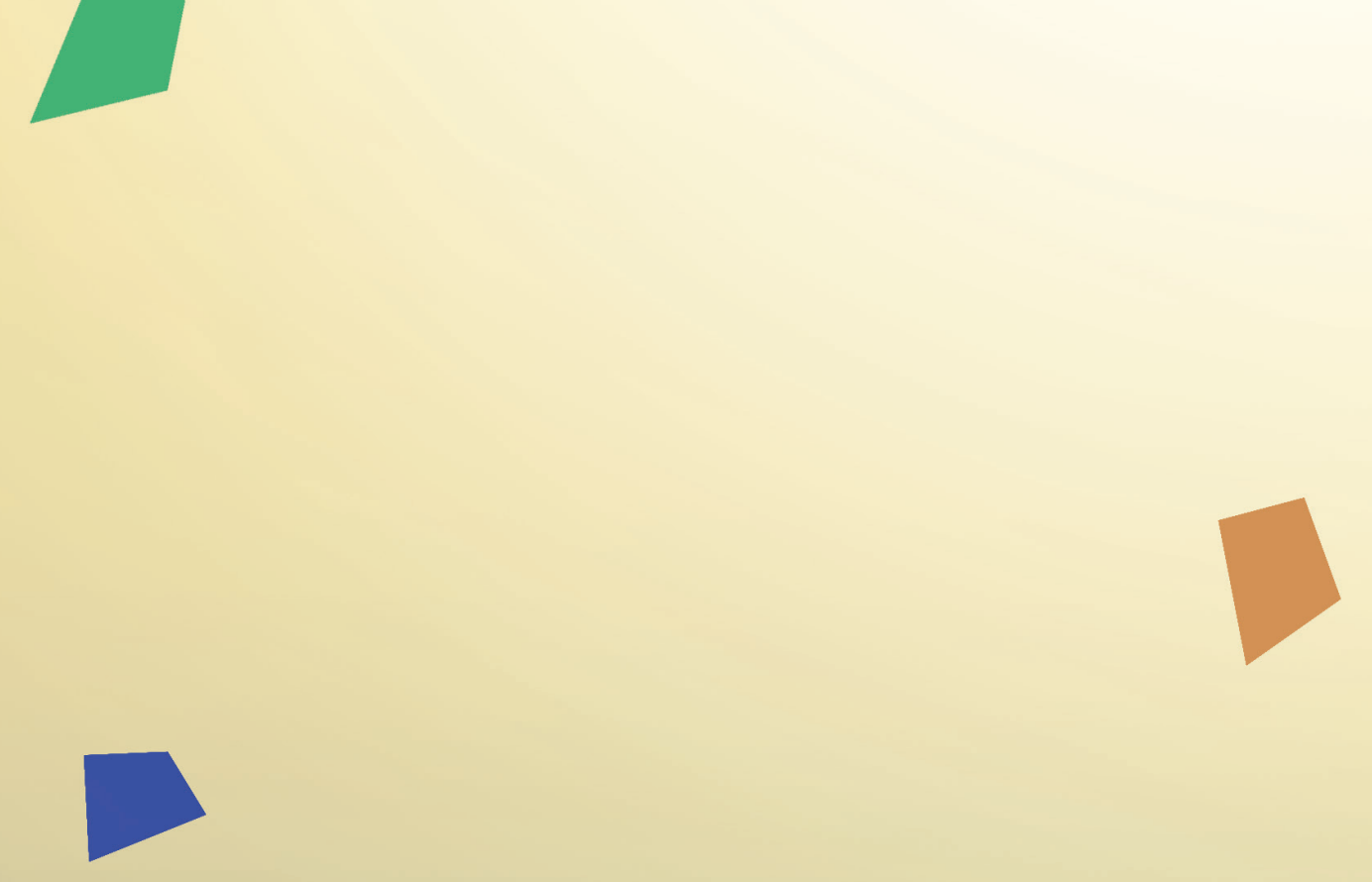

\section{Appendix}

Curriculum vitae List of publications and presentations Dankwoord 



\section{CURRICULUM VITAE}

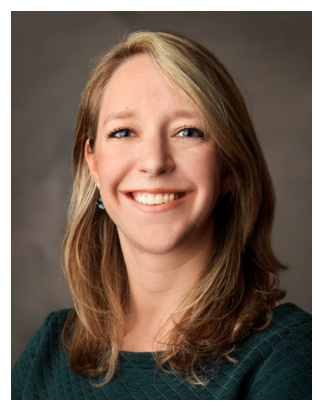

Maud Jansen is geboren op 30 juni 1989 te 's-Hertogenbosch. Ze is opgegroeid in Sittard, waar zij aan de Trevianum Scholengroep haar gymnasium diploma cum laude behaalde in de zomer van 2007. Hierna begon zij aan de Geneeskunde opleiding aan de Universiteit van Maastricht.

Tijdens het coschap Dermatologie in het Laurentius Ziekenhuis te Roermond werd haar interesse gewekt voor het vak Dermatologie. Om zich verder te verdiepen in de Dermatologie heeft zij haar laatste jaar van de studie Geneeskunde zowel haar wetenschappelijke als semi-arts stage bij de vakgroep Dermatologie van het Maastricht Universitair Medisch Centrum (MUMC+) voltooid.

In 2014 rondde zij haar Geneeskunde opleiding af en startte als arts-assistent dermatologie in het Antonius Ziekenhuis te Nieuwegein, waar zij onder de begeleiding van de dermatologen verder geënthousiasmeerd raakte op de drukke polikliniek.

In maart 2015 is zij begonnen aan een promotietraject onder begeleiding van prof. Dr. Steijlen, Dr. Mosterd en Dr. Kelleners-Smeets, hetgeen leidde tot dit proefschrift. In 2018 won Maud de eerste prijs op zowel het Pélerin Wetenschapssymposium in het MUMC+ als op het Europees congres voor Dermato-oncologie voor haar onderzoek naar de behandeling van actinische keratose.

Sinds december 2017 combineert Maud haar werkzaamheden met de opleiding Dermatologie in het MUMC+. 



\section{LIST OF PUBLICATIONS AND PRESENTATIONS}

\section{Publications}

Jansen MHE, Lijnen RLP, Lohman BGPM. Case report: Pseudoxanthoma elasticum en late onset focal dermal elastosis Nederlands Tijdschrift voor Dermatologie en Venerologie, volume 24, number 11

Jansen MHE, Appelen D, Nelemans PJ, Winnepenninckx VJ, Kelleners-Smeets NWJ, Mosterd K. Bowen's Disease: Long-term results of Treatment with 5-Fluorouracil cream, Photodynamic Therapy or Surgical Excision Acta dermato-venereologica 2018 Jan 12;98(1):114-115.

Jansen MHE, Mosterd K, Arits AHMM, Roozeboom MH, Sommer A, Essers BAB, van Pelt HPA, Quaedvlieg PJF, Steijlen PM, Nelemans PJ, Kelleners-Smeets NWJ. Five-year results of a randomized controlled trial comparing effectiveness of photodynamic therapy, topical imiquimod and topical 5-fluorouracil in patients with superficial basal cell carcinoma The Journal of Investigative Dermatology 2018 Mar;138(3):527-533.

Jansen MHE, Kessels JPHM, Kelleners-Smeets NWJ, Essers BA, Nelemans PJ, Mosterd K. Topicaal ingenol mebutate versus 5\% 5-fluorouracil versus 5\% imiquimod versus photodynamische therapie als behandeling van actinische keratosen: een multi-centre gerandomiseerde kosten effectiviteitsstudie: het protocol van de AKTI studie Nederlands Tijdschrift voor Dermatologie en Venerologie, volume 27, number 10

Jansen MHE, Sinx KAE, Kelleners-Smeets NWJ, Mosterd K. Senior commentary to: 'Longterm follow-up results of topical imiquimod treatment in basal cell carcinoma' Dermatologic Surgery 2019 Jan;45(1):144-145

Jansen MHE, Koekelkoren FHJ, Nelemans PJ, Arits AHMM, Roozeboom MH, KellenersSmeets NWJ, Mosterd K. Comparison of long term cosmetic outcomes for different treatment of superficial basal cell carcinoma Journal of the American Academy of Dermatology 2018 Nov; 79(5):961-964

Van Delft LCJ, Jansen MHE, Mosterd K, Kelleners-Smeets NWJ. Comment on "Guidelines of care for the management of basal cell carcinoma" Journal of the American Academy of Dermatology 2018 Nov; 79(5):e99-e100 
Jansen MHE, Kessels JPHM, Nelemans PJ, Kouloubis N, Arits AHMM, van Pelt HP, Quaedvlieg PJF, Essers BA, Steijlen PM, Kelleners-Smeets NWJ, Mosterd K. Randomized trial of four treatment approaches for actinic keratosis New England journal of medicine. 2019;380(10): 935-946

Van Delft LCJ, Nelemans PJ, Jansen MHE, Arits AHMM, Roozeboom MH, Abdul Hamid M, Mosterd K, Kelleners-Smeets NWJ. Histological subtype of treatment failures after noninvasive therapy for superficial basal-cell carcinoma: an observational study Journal of the American Academy of Dermatology 2018 Dec 21 pii: S0190-9622(18)33100-1

Jansen MHE, Özhan-Hasan H, Nelemans PJ, Winnepenninckx VJ, Kelleners-Smeets NWJ, Mosterd K. Trends in the incidence of Bowen's Disease in The Netherlands Accepted for publication in Dermatologic Surgery

\section{Oral presentations}

Actinic keratosis, when and how to treat? Skin cancer symposium, Centre of oncology MUMC+, Maastricht, the Netherlands, January 2016

Incidence of Bowen's Disease in the Netherlands. 37 th Annual Meeting 2016 of the ISDS (International Society for Dermatologic Surgery), Amsterdam, the Netherlands, September 2016

Bowen's Disease: Five-year results of Treatment with 5-Fluorouracil cream, Photodynamic Therapy and Surgical Excision, EURO-PDT 16 $6^{\text {th }}$ Annual Congress, Munich, Germany, February 2017

Aesthetic evaluation of treatment for superficial basal cell carcinoma, Oral presentation at $13^{\text {th }}$ Congress of the EADO (European Association of Dermato Oncology), Athens, Greece, May 2017

Topical ingenol mebutate versus 5\% 5-fluorouracil versus 5\% imiquimod versus photodynamic therapy in the treatment of actinic keratosis: a multi-centre randomized controlled trial, Oral presentation at GROW Science Day 2017, Maastricht, the Netherlands, November 2017

Topicaal ingenol mebutate versus 5\% 5-fluorouracil versus 5\% imiquimod versus photodynamische therapie als behandeling van actinische keratosen: een multi-centre gerandomiseerde kosten effectiviteitsstudie, Oral presentation at $344^{\text {th }}$ Scientific Meeting of Dutch Society for Dermatology and Venereology (NVDV), Maastricht, the Netherlands, December 2017 
Topical ingenol mebutateversus 5\% 5-fluorouracil versus 5\% imiquimodversus photodynamic therapy in the treatment of actinic keratosis: a multi-centre randomized efficacy and cost-effectiveness study, Oral presentation at $18^{\text {th }}$ Annual Meeting of Dutch Society for Experimental Dermatology, Lunteren, the Netherlands, February 2018

De schaduwzijde van de zon. Erytropoëtische protoporfyrie. Regional dermatology seminar of the Maastricht University Medical Centre+, Eindhoven, the Netherlands, September 2018

Topical ingenol mebutate versus 5\% 5-fluorouracil versus 5\% imiquimod versus photodynamic therapy in the treatment of actinic keratosis: a multi-centre randomized efficacy and costeffectiveness study, Oral presentation at Pélerin Symposium, Maastricht, the Netherlands, October 2018

Topical ingenol mebutate versus 5\% 5-fluorouracil versus 5\% imiquimod versus photodynamic therapy in the treatment of actinic keratosis: a multi-centre randomized efficacy and cost-effectiveness study, Oral presentation at $14^{\text {th }}$ Congress of the EADO (European Association of Dermato Oncology/9 $9^{\text {th }}$ World meeting of Interdisciplinary Melanoma/Skin Cancer Centers, Barcelona, Spain, November 2018

Comparative RCT of topical AK therapies: 1 year results, Oral presentation at $2^{\text {nd }}$ Cells to Surgery congress, Rotterdam, the Netherlands, February 2019

Topicale behandeling van actinische keratosen: resultaten van een gerandomiseerde multicenter trial, Oral presentation at Dermatologen Dagen, Utrecht, the Netherlands, March 2019

\section{Awards}

First price, Pélerin Wetenschapssymposium, Maastricht, the Netherlands, October 2018 $€ 5000$

Best oral presentation at $14^{\text {th }}$ Congress of the EADO (European Association of Dermato Oncology)/9th World meeting of Interdisciplinary Melanoma/ Skin Cancer Centers, Barcelona, Spain, November 2018

$€ 500$

Breaking News Award 2018, 20 ${ }^{\text {th }}$ Annual Meeting of Dutch Society for Experimental Dermatology, February 2019 



\section{DANKWOORD}

Ineens is het dan zo ver! Het proefschrift is afgerond, tijd om het dankwoord te schrijven. Een proefschrift schrijf je niet alleen en dit was niet gelukt zonder de steun van velen. Graag wil ik een aantal mensen in het bijzonder bedanken.

Beste Professor Steijlen, bedankt dat u mij een aantal jaar geleden de kans heeft gegeven om aan dit grote project te beginnen. Vanaf dag één gaf u mij het vertrouwen dat het een succes zou worden. Bedankt voor alle mogelijkheden die ik heb gekregen om naar diverse congressen en cursussen te gaan. Daarnaast heel veel dank dat ik vanuit het onderzoeksproject mocht starten met de opleiding.

Beste dr. Mosterd, lieve Klara, je bent een fantastische begeleidster en echt een onderzoekster in hart en nieren. Je staat altijd klaar, bent enthousiast en heel kritisch. Je directheid en scherpe blik zorgden er altijd voor dat het nog nét ietsje beter kon en heeft geleid tot de prachtige publicaties en presentaties. Dank ook voor alle gezelligheid op de congressen die we samen hebben bezocht.

Beste dr. Kelleners-Smeets, lieve Nicole, dankzij jou is mijn interesse in het doen van onderzoek ontstaan toen ik als WESP student een aantal jaar geleden begon. Je bent een super begeleidster: je reageert altijd snel op mails en vragen en je bent een echte motivator. Je hebt me enorm gesteund bij het afronden van de TTOP toen dat erg lastig was. Bedankt voor je optimisme en ik denk met veel plezier terug aan alle dansjes op feesten en congressen.

Beste leden van de beoordelingscommissie, prof. dr. Dirksen, prof. dr. Nijsten, prof. dr. Cals en dr. Beljaards, bedankt voor het lezen en beoordelen van het manuscript.

Beste dr. Nelemans, lieve Patty. Bedankt dat je me wegwijs hebt gemaakt en enthousiast hebt gekregen over epidemiologie en statistiek. Regelmatig klopte ik met de handen in het haar bij je aan en kwam ik opgewekt bij jou vandaan omdat jij me weer verder had geholpen. Ook wil ik je bedanken voor je altijd scherpe blik. Je bent kritisch en een taalpurist, wat ervoor zorgde dat onze stukken naar een hoger niveau getild werden. Daarnaast bedankt voor de leuke gesprekken die we hadden en jouw verhalen over al je reizen. Ik zal nooit vergeten wat een pofadder is.

Beste dr. Essers, lieve Brigitte. Heel veel dank voor je altijd snelle en nuttige reacties op artikelen en vragen. Je bent rustig, geduldig en denkt altijd in oplossingen. Door je goede opmerkingen liet je me kritisch nadenken over de keerzijde van het verhaal en wat dit allemaal betekende voor de praktijk. 
Mijn liefste paranimfen, bedankt dat jullie naast mij willen staan op deze bijzondere dag! Lieve Janneke, ik ken weinig duizendpoten zoals jij. Bedankt dat je mijn perfecte maatje was bij de AKTI: jij hield van schrijven (en daarnaast typt niemand zo snel als jij), ik de statistiek. Ik vind het heel bijzonder hoe jij altijd alles weet te combineren en altijd vrolijk en oprecht bent. Bedankt voor je ontelbare hulp bij mijn promotie! Lieve Janna, je bent echt een goudstuk! Ik ben enorm blij met een collega en vriendin zoals jij. Altijd attent en lief. Dank voor al je steun, rust, reflectie, oppepberichtjes en de vele hilarische avonturen. Ik hoop dat er nog veel volgen!

Zonder patiënten geen onderzoek. Aan alle patiënten heel veel dank voor het deelnemen aan en vertrouwen in het onderzoek.

Daarnaast ook veel dank aan alle artsen, verpleegkundigen, physician assistants, nurse practioners, polidames en secretaresses van de afdelingen Dermatologie van het MUMC+, Catharina Ziekenhuis, VieCuri MC, Zuyderland MC, Laurentius Ziekenhuis, Elkerliek Ziekenhuis en Jeroen Bosch Ziekenhuis voor jullie hulp bij de AKTI en de TTOP.

Daarnaast dank aan alle co-auteurs voor de fijne samenwerking. Zonder jullie hulp waren het niet zulke mooie publicaties geworden!

Lieve dames van het secretariaat, lieve Nicole, Annelies, Petra, Ingrid, Nandy en Sanne. Bedankt voor het beantwoorden van alle (soms bijzondere) vragen van mijn onderzoekspatiënten. Jullie kunnen intussen als geen ander de behandelingen van actinische keratose uitleggen. Daarnaast heel veel dank voor jullie goede adviezen en interesse en dat ik altijd mijn verhaal bij jullie kon doen.

Lieve Kelly, mijn maatje in het onderzoekshok op Oxford. Je bent een schat! Je bent altijd bereid te helpen of mee te denken. Bedankt voor het leuke gezelschap en het luisterend oor wanneer ik even wat frustratie kwijt moest.

Lieve mede (oud-)promovendi, bedankt voor al jullie input tijdens onze onco-meetings. Lieke, nogmaals bedankt voor jouw hulp bij de laatste loodjes en het sparren over mijn discussie. Ik vind het knap hoe je altijd alle artikelen paraat hebt.

Lieve Kiki, nog steeds zo oneerlijk. Het hoofdstuk over de behandelingen van BCC hoorde eigenlijk in jouw boekje te staan. Ik hoop dat je met trots kijkt naar de studies die we afgemaakt hebben en je er zo nog steeds een beetje bij bent. Ik mis je.

Beste collega (oud-)AIOS en stafleden van de afdeling Dermatologie van het Maastricht Universitair Medisch Centrum: bedankt dat jullie het iedere dag weer een feest maken om naar het werk te gaan! 
Beste drs. Nagtzaam, beste Ivo, bedankt voor de ruimte die ik heb gekregen in het eerste jaar van mijn opleiding om het onderzoek af te ronden. Daarnaast bedankt voor alle energie die je in onze opleiding steekt.

Beste dr. Reinders, lieve Marieke, bedankt dat je mijn mentor wil zijn. Je weet als geen ander hoe de laatste loodjes van een promotie zijn. Bedankt voor al je hulp, motivatie en steun.

Lieve Marloes en Femke, mijn voorgangsters uit het Antonius. Dank voor jullie steun, vrolijkheid en goede adviezen. Lieve Charlotte, altijd relaxt en relativerend, dankjewel voor de goede gesprekken en borrels. Lieve Marigje, jij bent de meest attente persoon die ik ken! Bedankt voor je luisterend oor, gezelligheid en motivatie. Lieve Lieks, bedankt dat ik altijd bij je terecht kan voor álles, je bent een schat! Lieve Marieke, dank voor al je hulp bij de TTOP, zelfs toen je met zwangerschapsverlof was. Lieve Tjinta, je bent een enorme doorzetter, bedankt voor je altijd oprechte interesse. Lieve Nadine, in hetzelfde jaar in opleiding en mijn COCOM-buddy, bedankt dat ik mijn verhalen en belevenissen bij je kwijt mag.

Beste dr. Goedkoop, drs. Koppen, drs. Meijer, dr. Pruissen, dr. Steegmans en dr. Tupker, beste Amber, Sander, Babs, Kim, Paul, en Ron, bedankt voor de fantastische tijd die ik bij jullie op de polikliniek gehad heb en alles wat ik van jullie heb geleerd. Ik pluk er nog dagelijks de vruchten van! Ik hoop dat we de reünies in ere kunnen houden.

Beste Evelien en Mariska, bedankt voor de hulp bij het opmaken en ontwerpen van het boekje. Het is prachtig geworden.

Zonder ontspanning was dit boekje er nooit geweest! Lieve KoKo maatjes, Wooden Spoons, Aegles, gympikken, de dameskamer van Maastricht, bedankt voor alle fantastische momenten en dat jullie altijd voor me klaar staan. Lieve Simon, je staat bovenaan mijn whatsapp lijst. Niemand die zo snel reageert als jij, zelfs als het over onzin gaat. Ik kan enorm met je lachen en alles bij je kwijt. Bedankt voor de prachtige reizen, ik hoop dat er nog veel volgen. Lieve Erwin en Michelle, vanaf dag 1 zijn we studievrienden. Bedankt voor alle studiemomentjes, maar ook feestjes en natuurlijk mooie reizen naar Sri Lanka, Suriname en Australië. Lieve Isa, we zien elkaar te weinig, maar ik vind het altijd super fijn met jou! Je bent intens lief, altijd oprecht geïnteresseerd en super creatief. Lieve Woody \& Jeroen, Tim \& Heleentje, ik voel me kind aan huis bij jullie en loop de deur dan ook plat, zowel in Maastricht als Den Bosch. Bedankt dat ik echt altijd mag aanschuiven voor een etentje, drankje, spelletje, maar ook voor een goed gesprek! Lieve Emmy, ik vind het enorm knap hoe jij je inzet voor je studie, niet altijd makkelijk, maar je bent een enorme doorzetter! Ben heel erg trots op je! Lieve Hanne, mijn atletiekvriendinnetje. Ik heb er bewondering voor hoe jij een drukke baan kunt combineren met het voltooien van een master, en dat tijdens je zwangerschap! Ik hoop dat we onze verjaardagsdates in stand houden. Lieve Camille, wat moet 
ik zonder jou. Altijd heb je alles al geregeld voordat ik er zelf maar over na heb kunnen denken. Bedankt voor alle hulp met de locatie, maar ook al je gezelligheid en oprechtheid. Lieve Fayette, bedankt voor al onze bourgondische, tennis- en JCI-momentjes. Lieve Maik, bijna tegelijk klaar! Van samen schrijven op het balkon tot het beleven van allerlei andere avonturen. Bedankt voor al je energie, optimisme en kritische blik!

Lieve schoonfamilie, bedankt voor jullie grote interesse in mijn onderzoek en dat ik me zo thuis voel bij jullie.

Lieve papa en mama. Ik kan niet omschrijven hoeveel jullie voor me hebben gedaan. Bedankt voor alle steun door de jaren heen. Jullie zijn er echt áltijd voor me en voor alles, op welk tijdstip of vanaf welke plek ik ook bel. Zonder jullie was ik hier nooit gekomen! Lieve Rob, je bent het beste broertje die ik me kan wensen. Altijd geïnteresseerd en oprecht. Ik ben enorm trots op hoe jij je studie hebt afgerond en nu je plek in Den Haag hebt gevonden!

Liefste Pieter, last but not least! Bedankt dat je me in de afgelopen periode zo enorm gesteund hebt! Jouw rust zorgde ervoor dat ik dit proefschrift kon afmaken. Je motiveerde me als ik er even helemaal klaar mee was, maar zorgde er ook voor dat ik niet uren zat te werken. Ik kan niet beschrijven hoe waardevol dat was! Nu gelukkig meer tijd om samen leuke dingen te doen. Mi lobi yu. 